\title{
SUSTAINABLE TOURISM IN PROTECTED AREAS AS A DRIVER FOR ENVIRONMENTAL CONSERVATION AND COMMUNITY DEVELOPMENT IN GUATEMALA
}

\author{
By \\ Cesar Rene Gonzalez \\ Honours Bachelor of Science, University of Toronto, Toronto, 2012 \\ A thesis \\ presented to Ryerson University \\ in partial fulfillment of the \\ requirements for the degree of \\ Master of Applied Science \\ in the Program of \\ Environmental Applied Science and Management
}

Toronto, Ontario, Canada, 2014

(C) Cesar R. Gonzalez 2014 


\section{AUTHOR'S DECLARATION FOR ELECTRONIC SUBMISSION OF A THESIS}

I hereby declare that I am the sole author of this thesis. This is a true copy of the thesis, including any required final revisions, as accepted by my examiners.

I authorize Ryerson University to lend this thesis to other institutions or individuals for the purpose of scholarly research.

I further authorize Ryerson University to reproduce this thesis by photocopying or by other means, in total or in part, at the request of other institutions or individuals for the purpose of scholarly research.

I understand that my thesis may be made electronically available to the public. 


\title{
Sustainable Tourism in Protected Areas as a Driver for Environmental Conservation and Community Development in Guatemala
}

Master of Applied Science, 2014

\author{
Cesar R. Gonzalez \\ Environmental Applied Science and Management \\ Ryerson University
}

\begin{abstract}
Developing sustainable tourism in protected areas is of interest because of their marketable settings for outdoor activities in natural environments and for their role in protecting cultural and natural assets. Managing and planning these areas for tourism poses challenges because of issues pertaining to income generation, community development, and visitor management. The region of Lake Izabal-Rio Dulce in Guatemala contains three protected areas - Cerro San Gil, Rio Dulce National Park, and Chocon Machacas - that are significant in protecting biodiversity but are not effectively managed for tourism. Through a case study and a multi-method approach to collect data, the perspectives of selected tourism planning and management organizations and tourists were investigated to gauge sustainable tourism initiatives and identify vulnerable zones in the protected areas. The findings show that community development has lagged, visitor management is required, and a greater extent of collaboration is needed to support sustainable tourism development.
\end{abstract}




\section{Acknowledgements}

The completion of this thesis would not have been possible without the support and guidance of many. First, I would like to thank my supervisor Dr. Kelly MacKay for giving me the opportunity, encouragement, and guidance to develop my skills and confidence as a researcher.

I would like to thank my thesis committee for taking an interest in my research and the time to provide feedback. To Dr. Doug Banting, thank you for providing feedback on questions I had with GIS.

To my family, Laura, Kristen, and my parents: thank you for your encouragement, support, and for always believing in me.

To those who participated in the study, and to my local guide, Baldomero, who provided me with a home during the week I was in Izabal, thank you for taking the time to engage in my study and for your enthusiasm to answer any questions I had. It certainly helped in times of difficulty collecting data.

Finally, a special thank you to my friends for being editors, readers, for providing ideas and motivation to move forward with my thesis, for reassurance in times of doubt, and for confiding in me.

Thank you. 


\section{Table of Contents}

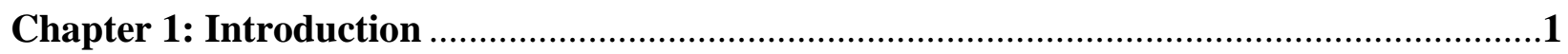

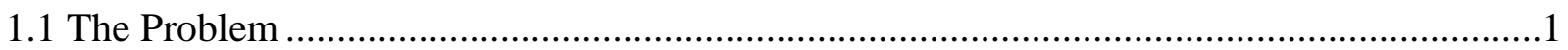

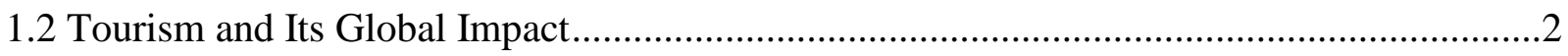

1.3 Tourism in Central America and Guatemala................................................................4

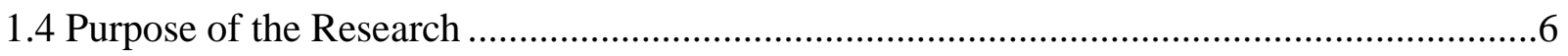

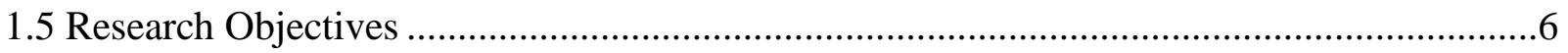

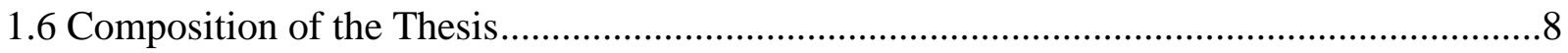

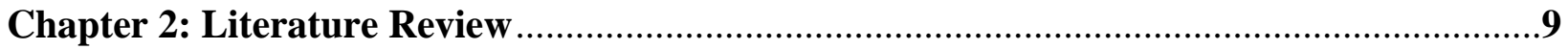

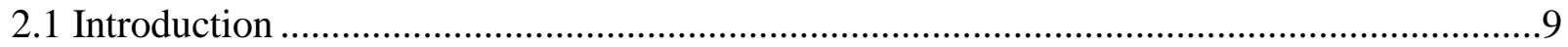

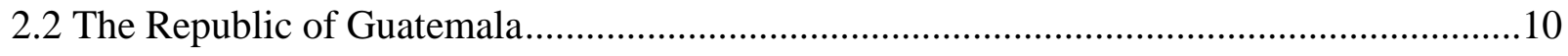

2.3 The Development of Tourism in Guatemala ............................................................11

2.3.1 Historical Influences on Tourism ...............................................................13

2.3.2 Contemporary State of Tourism in Guatemala...................................................14

2.3.3 Tourism in the Department of Izabal................................................................16

2.4 Sustainability and Sustainable Development .........................................................18

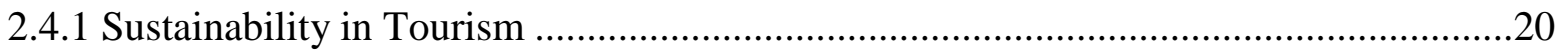

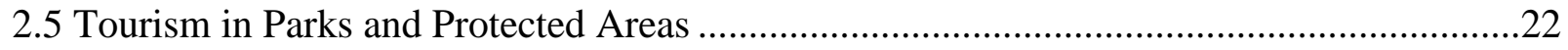

2.5.1 Organizational Management and Collaboration................................................24

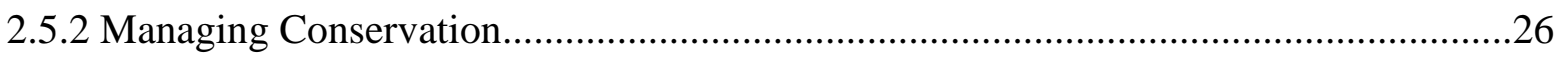

2.5.3 Communities in Protected Areas ............................................................................28

2.5.4 Income Generation and Visitor Management...................................................29

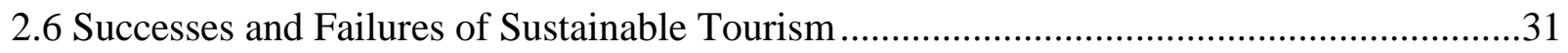




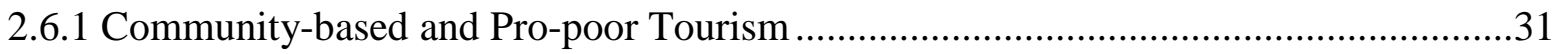

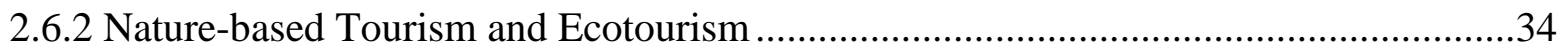

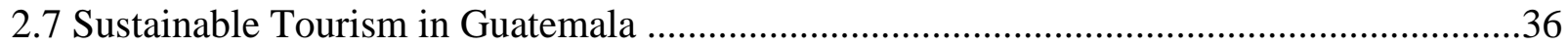

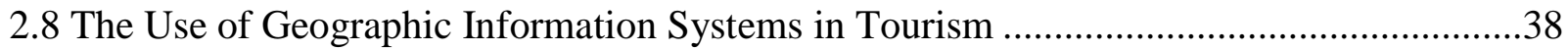

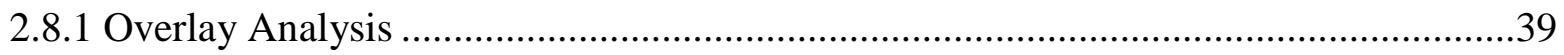

2.8.2 Case Studies in GIS .................................................................................4

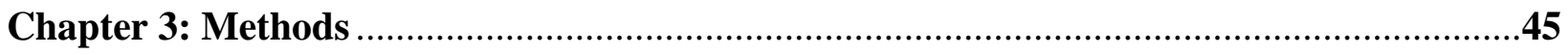

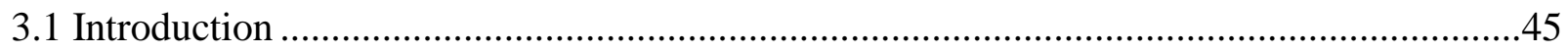

3.2 Multi-method Case Study Design ...........................................................................45

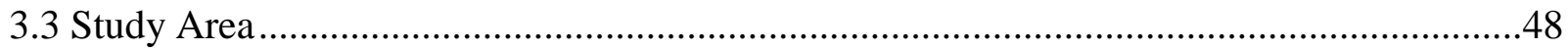

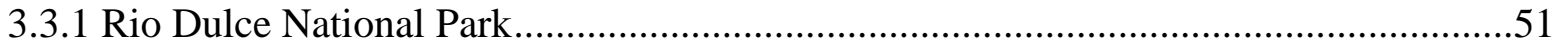

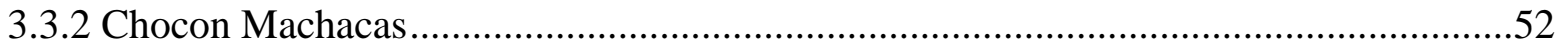

3.3.3 Cerro San Gil ...........................................................................................

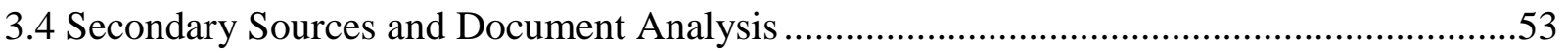

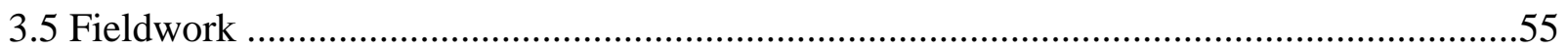

3.6 Interviews with Key Stakeholders.....................................................................5

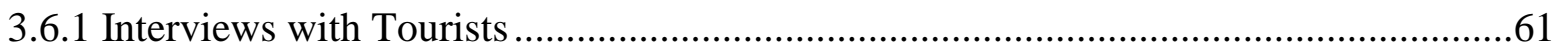

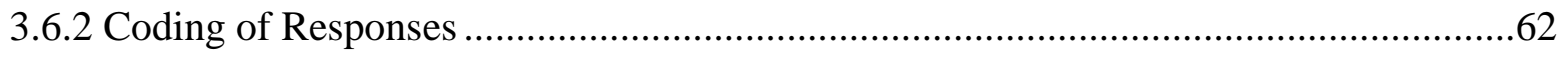

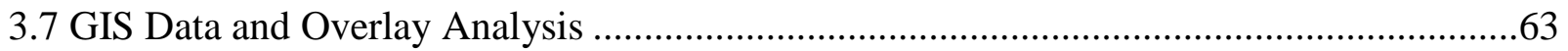

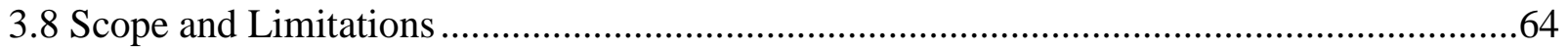

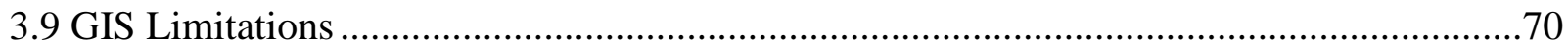

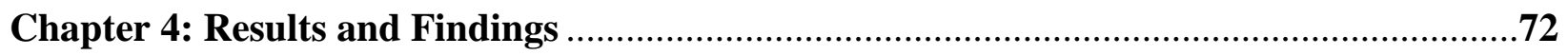

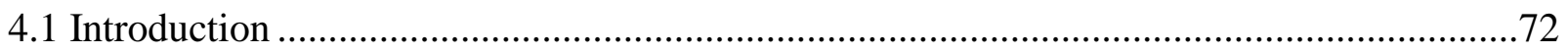


4.2 Overall Perspectives on Protected Areas and Tourism in Izabal

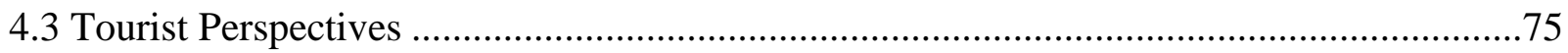

4.3.1 Influences on Tourist Arrivals in Izabal ……….........................................................78

4.4 Perspectives of Planning and Management Stakeholders ……………………...................82

4.4.1 Perceived Obstacles to Tourism Development.........................................................82

4.4.2 Perspectives on Social, Economic, and Environmental Impacts....................................85

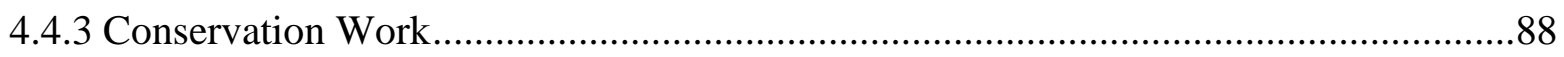

4.4.4 Overarching Management and Planning Processes.......................................................89

4.5 Influences on Communities' Sustainable Development ……………………………...........91

4.6 Identification of Vulnerable Areas through GIS ……………...........................................95

Chapter 5: Discussion, Recommendations, and Conclusion .............................................104

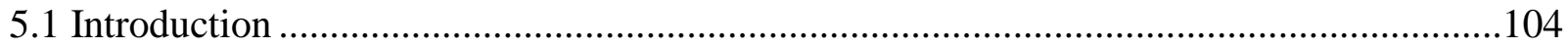

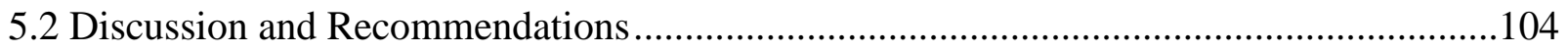

5.2.1 Institutional Governance and Collaboration..............................................................105

5.2.2 Community Development ……………………..................................................108

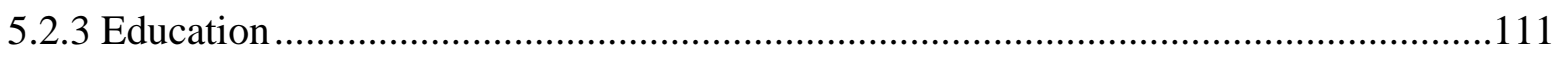

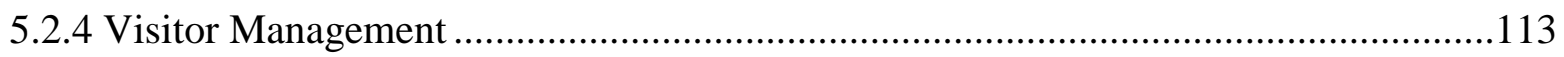

5.2.5 Environmental and Tourism Implications in Vulnerable Areas ..................................115

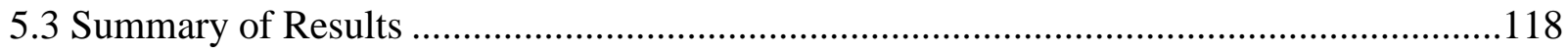

5.4 Contributions and Further Research.............................................................................120

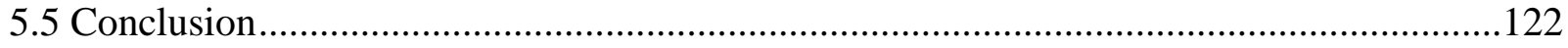

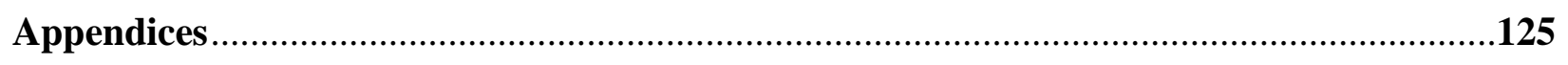

Appendix A: Consent form for park planners and managers (English and Spanish)..............125 
Appendix B: Interview guide for park planners and managers .......................................133

Appendix C: Consent form for tourists (English and Spanish) .......................................135

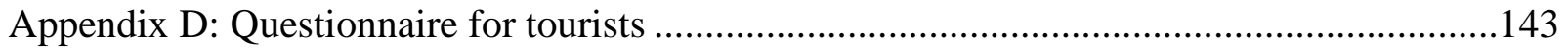

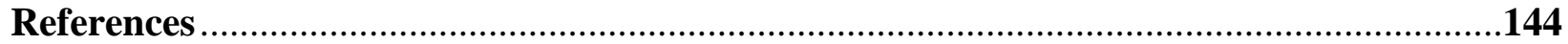




\section{List of Tables}

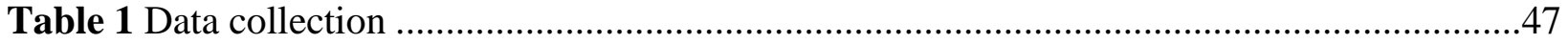

Table 2 List of protected areas examined in this study .......................................................51

Table 3 Tourism activities in the protected areas in Izabal...............................................54

Table 4 Facilities and services in the protected areas in Izabal ...........................................55

Table 5 Schedule of areas visited and work conducted ......................................................58

Table 6 Perspectives on tourism in protected areas in Guatemala ...........................................73

Table 7 Factors that attracted tourists to the protected areas in Izabal ....................................77

Table 8 Potential improvements to tourism as suggested by tourists .....................................79

Table 9 Obstacles related to the management and planning of the protected areas in Izabal.......83

Table 10 Main lines of conservation work conducted in the protected areas .............................88

Table 11 Environmental pressures affecting the protected areas in Izabal .............................92 


\section{List of Figures}

Figure 1 International tourist arrivals in thousands by destination country in $2012 \ldots \ldots \ldots \ldots \ldots \ldots . . . .4$

Figure 2 Objective 1 indicating the intersection of tourists and park planning and management organizations at the junction of the protected areas and the communities within those areas.........7

Figure 3 Guatemala's location within Central America with neighbouring countries labeled.....11

Figure 4 Map of Guatemala's main tourist destinations .................................................15

Figure 5 Growth in protected areas from 1990 to 2010 by percentage of terrestrial area ...........23

Figure 6 Map of Izabal, major roadways and towns, and the Lake Izabal-Rio Dulce system......48

Figure 7 Map of the protected areas, including location of temporary stay (Campo Dos)..........49

Figure 8 GIS overlay analysis showing the layers superimposed on one another and an overlay function performed to produce a composite map of vulnerability.

Figure 9 Tourist arrivals to Guatemala for the year 2012 .................................................66

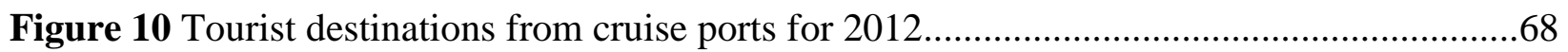

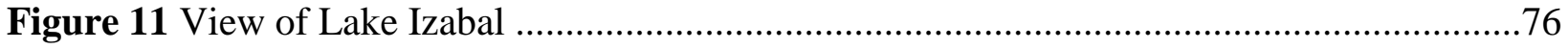

Figure 12 Scenic view of Lake Izabal, litter in the foreground and the sign obscured...............80

Figure 13 Signage in Spanish which translates to "Take care of this park, it's yours" in front of an outdoor gift shop

Figure 14 An information sign in both Spanish and English along a trail in Cerro San Gil informing tourists and visitors about the impact of deforestation

Figure 15 Deforestation in Izabal.

Figure 16 Overarching management and planning processes for the protected areas in Izabal ...90

Figure 17 Layer 1 showing population size for the communities within the protected areas.......97

Figure 18 Layer 2 showing land cover within the protected areas .....................................98

Figure 19 Layer 3 species diversity per square kilometre ..............................................99

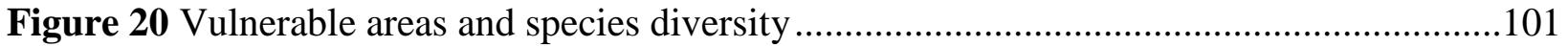




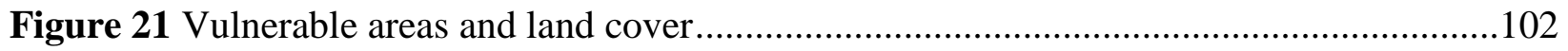

Figure 22 Continuum of governance possibilities in protected areas ....................................108

Figure 23 Summary map containing main towns around the protected areas ........................116 


\begin{tabular}{|c|c|}
\hline & Abbreviations \\
\hline AMASURLI & $\begin{array}{l}\text { Autoridad para el Manejo Sustentable de la Cuenca Hidrográfica del } \\
\text { Lago de Izabal y Río Dulce: Authority for the Sustainable Management of } \\
\text { the Lake Izabal and Rio Dulce Watershed }\end{array}$ \\
\hline CAMTUR & Cámara de Turismo de Guatemala: Chamber of Tourism of Guatemala \\
\hline CBT & Community-based tourism \\
\hline CECON-USAC & $\begin{array}{l}\text { Centro de Estudios Conservacionistas - Universidad de San Carlos de } \\
\text { Guatemala: Center for Conservation Studies - University of San Carlos of } \\
\text { Guatemala }\end{array}$ \\
\hline CONAP & $\begin{array}{l}\text { Consejo Nacional de Areas Protegidas: The National Council of Protected } \\
\text { Areas }\end{array}$ \\
\hline FUNDAECO & $\begin{array}{l}\text { Fundación Para El Ecodesarrollo y la Conservación: Foundation for } \\
\text { Ecodevelopment and Conservation }\end{array}$ \\
\hline GIS & Geographic Information Systems \\
\hline INE & $\begin{array}{l}\text { Instituto Nacional de Estadistica Guatemala: National Institution of } \\
\text { Statistics of Guatemala }\end{array}$ \\
\hline INGUAT & Instituto Guatemalteco de Turismo: Guatemalan Institute of Tourism \\
\hline NGO & Non-governmental Organization \\
\hline NREL & National Renewable Energy Laboratory \\
\hline PPMO & Park Planning and Management Organizations \\
\hline RDNP & Rio Dulce National Park \\
\hline SEGEPLAN & $\begin{array}{l}\text { Secretaría de Planificación y Programación de la Presidencia: Ministry } \\
\text { of Planning and Programming of the Presidency }\end{array}$ \\
\hline SIGAP & $\begin{array}{l}\text { Sistema Guatemalteco de Áreas Protegidas: Guatemalan Protected Areas } \\
\text { System }\end{array}$ \\
\hline TNC & The Nature Conservancy \\
\hline WTO & World Tourism Organization \\
\hline
\end{tabular}




\section{Chapter 1}

\section{Introduction}

\subsection{The Problem}

Tourism is widely recognized as a means to stimulate local economic development through creating jobs and increasing foreign revenue (Geneletti \& Dawa, 2009). Tourism, however, is not without its shortcomings. In addition to negative impacts on local air, water, and soil quality, social and cultural fabrics are also affected (Buckley, 2012). Nonetheless, when developed in a sustainable manner, tourism can fulfil economic needs while maintaining cultural integrity, biological diversity, essential ecological processes, and life support systems (Diamantis \& Ladkin, 1999). Protected areas are of interest in sustainable tourism development as attractive and marketable settings for tourism because of their potential role in protecting cultural and natural assets while providing a setting for outdoor activities (Eagles, McCool, \& Haynes, 2002). Protected areas that have limited control over access points or include inhabited communities pose unique challenges in the management of such areas (WTO, 2004).

Destinations with environmental resources that translate well into tourism opportunities, such as in Guatemala, can be negatively impacted by conflicts and multifaceted governance issues (European Commission, 2007). Tourism operating rights on communal property, for instance, are complex and their contribution to community well-being and biodiversity conservation are not well understood (Buckley, 2012). Geographic information systems (GIS) as a tool for spatial analysis can be used to explore conflicts, examine impacts, and assist in decision-making processes to achieve sustainable tourism development (Bahaire \& Elliott-White, 1999). Although the use of GIS in environmental planning and management has increased, its application to tourism planning remains limited (Ólafsdóttir \& Runnström, 2009). 
In the Caribbean region of Guatemala, studies have mostly focused on lake management pertaining to water-level fluctuations and bio-invasions (Binimelis, Monterroso, \& RodriguezLabajos, 2007; Medina, Gomez-Enri, Alonso, \& Villares, 2008), or on the economic sustainability of the region, but are dated (Perlack, Ensminger, \& Martinez, 2001). Hence, the purpose of this study is to explore the extent to which protected areas in the Lake Izabal-Rio Dulce region of Guatemala are being managed for the purposes of sustainable tourism development and how issues pertaining to community development and conservation are being addressed with respect to the environmental, social, and economic implications of development.

\subsection{Tourism and its Global Impact}

Transnationalism, globalization, and the development of new forms of communications media have, in contemporary times, influenced the mobility and connectivity of tourism (Hall, 2011). Tourism represents a complex and dynamic phenomenon present in practically every corner of the world, affecting people in various ways (Salazar, 2012). In 2012 alone, a year characterized by an unstable economy and regional conflicts in a global context, the tourism sector showed its resilience in the number of international tourists for one year, which exceeded one billion for the first time (WTO, 2013). Indeed, tourism is one of the largest economic sectors in the world conducted by societies in both developed and developing countries and is considered an element in poverty reduction efforts (WTO \& UNEP, 2008).

The designation of protected areas is a key component of global conservation strategies (Dearden, Bennett, \& Johnston, 2005). As such, protected areas and national parks are increasingly marketed as destinations and tourists are either welcomed as a potential source of 
revenue or unwelcomed as additional stress on the systems that the area was designed to protect (WTO, 2004). Several authors have noted the economic contribution from tourist receipts in the form of developing services, such as lodging and restaurants, generating income for communities, and conservation (Eagles et al., 2002; Lyon, 2013; MacKay \& Campbell, 2012). The lack of management regulations and conflict between government agencies can produce threats to the protected areas, either as degenerative environmental pressures or the prevention of community development (Beneditti, 2013; Hassanali, 2013). Tourism to Tobago's Buccoo Reef Marine Park, for example, has resulted in improved economic development but lagged in social and community development due to the marginalization of local people's roles in management and decision-making procedures (Hassanali, 2013).

Biodiversity has been found to have a significant and positive correlation with inbound tourist receipts, indicating that the relationship between biodiversity and tourism development is important (Freytag \& Vietze, 2013). The lack of proper tourism management and policies, however, can damage sensitive ecosystems in protected areas, having implications that range from a decrease in visitor satisfaction to a decline in the number of visitors, both of which result in the loss of economic benefits that tourism may bring (Ólafsdóttir \& Runnström, 2009). In developing regions, environmental degradation is magnified because of difficulties in earning an alternative livelihood and a lack of infrastructure and planning policies (Geneletti \& Dawa, 2009). Hence, maintaining ecosystems, and therefore the environment, remains an important objective for tourism planners. Protected areas have the potential to contribute to conservation if they are well-managed, which includes the availability of funding, the support for capacity building, and the level of effective community involvement (Dearden et al., 2005). 


\subsection{Tourism in Central America and Guatemala}

The restructuring of the economy of countries in Central America was motivated, in part, by a declining competitiveness of the agriculture sector (Croes \& Kubickova, 2013). In looking to other non-traditional sectors, such as services and manufacturing, the tourism industry in Central America became much more active (Croes \& Kubickova, 2013). Between the years 2011 and 2012, Central America experienced a 7.3\% growth rate in terms of international tourist arrivals, followed by South America with 5.0\%, North America with 4.5\%, and the Caribbean with 3.7\% (WTO, 2013). In Guatemala, tourism experienced a significant growth of $6.5 \%$ between the years of 2011 and 2012 (WTO, 2013). As shown in Figure 1 below, Guatemala received approximately 1.3 million visitors in 2012 .

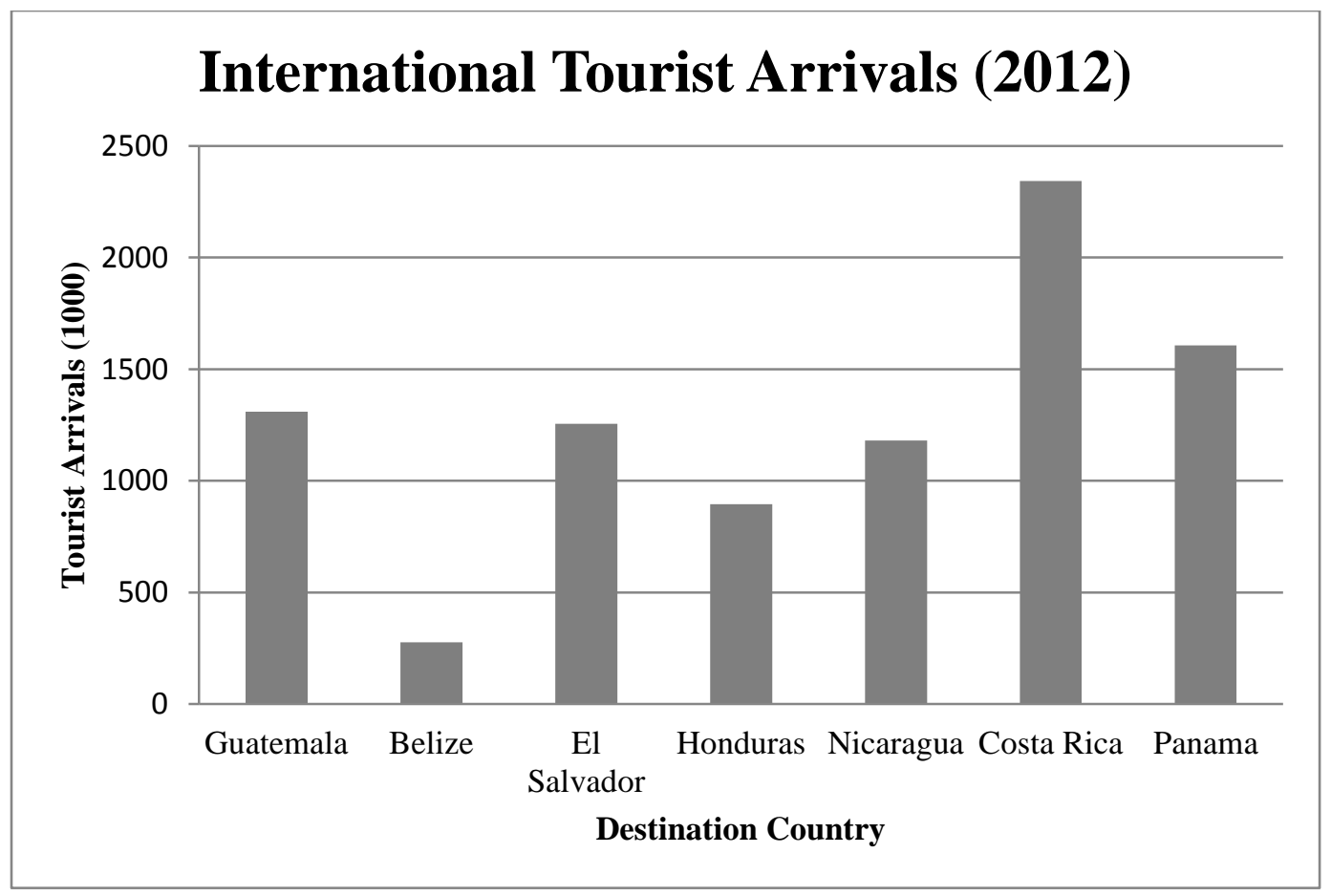

Figure 1 International tourist arrivals in thousands by destination country in 2012. Adapted from WTO (2013). 
While tourism has been embraced as a strategy to reduce poverty and foster economic development in Central America, its effect has been uneven as some countries have had a longer history of tourism development than others (Croes \& Kubickova, 2013). Guatemala's tourism history, for instance, is very recent (Crispín, Beltrán, \& Frejomil, 2012). Figure 1 demonstrates that Costa Rica and Panama generated higher numbers of international tourist arrivals than Guatemala in 2012 and have been more successful in attracting tourists. Even within countries, tourism development has been uneven. Tourism in Guatemala, for example, is mostly concentrated in Tikal, for the Maya culture and ancient pyramids, Antigua, cited for its historical quality as a colonial city, and Guatemala City, as the main hub for tourist arrivals (Crispín et al., 2012).

The uneven distribution of tourism development in Guatemala has implications for travel to protected areas as they also serve to contribute to tourism development potential (European Commission, 2007). The natural abundance of Guatemala includes fertile lands for corn fields, banana plantations and coffee production, as well as sensitive ecosystems that maintain a diverse range of species of birds and amphibians. Protected areas like the Maya Biospehere Reserve in Petén, Guatemala, considered one of Central America's largest and most isolated, have not been developed for ecotourism despite, in this case, containing the well-visited archeological site of Tikal (Hearne \& Santos, 2005). Protected areas in Izabal, such as Cerro San Gil and Rio Dulce National Park, require policies and regulations to reverse destructive environmental trends and ensure long-term sustainable use of natural resources in the region (Perlack et al., 2001). This has proved challenging, however, as sustainable development has been constantly affected by environmental degradation in Guatemala (Berger, 1997; Sundberg, 1998). 


\subsection{Purpose of the Research}

Research remains to be conducted in the field of sustainable tourism development in the protected areas of Izabal, Guatemala, as attention is mostly given to the management of Lake Izabal. In terms of tourism research, a large focus is placed on popular tourist attractions in Guatemala (e.g., Tikal and Antigua) and their development. Research on protected areas focuses on several regions of Guatemala other than Izabal (Bonham, Sacayon, \& Tzi, 2008; Hearne \& Santos, 2005; Smith \& Ley, 2009) or is otherwise dated (Perlack et al., 2001). Sustainable tourism must also take into account economic, social, and environmental pillars. The management of the protected areas in Izabal is of interest because little is known about its effect on tourism to Guatemala, environmental conservation goals for a region of ecological importance (Medina et al., 2008), and the level of community development.

The overarching question that forms the starting point for the research is: how can sustainable tourism development in protected areas act as a driver for environmental conservation and community development in the region of Lake Izabal-Rio Dulce in Guatemala, which contains a vast, yet fragile amount of biodiversity and natural resources? From this, the overarching research question was narrowed to identify specific research objectives, which are described in section 1.5.

\subsection{Research Objectives}

The question is deconstructed into two research objectives. The first objective is to understand the perspectives of tourists and park planning and management organizations (PPMO) towards sustainable tourism development and the local communities within the protected areas in the 
Lake Izabal-Rio Dulce region. In particular, the research explores the economic, social, and environmental implications of tourism in the protected areas of Rio Dulce National Park, Cerro San Gil, and Chocon Machacas. The implications include, but are not limited to, income generation, community involvement in tourism planning and management, and environmental conservation efforts. Specifically, these implications are examined to gauge the region's sustainable development initiatives for tourism. Figure 2 is a schematic of the first objective.

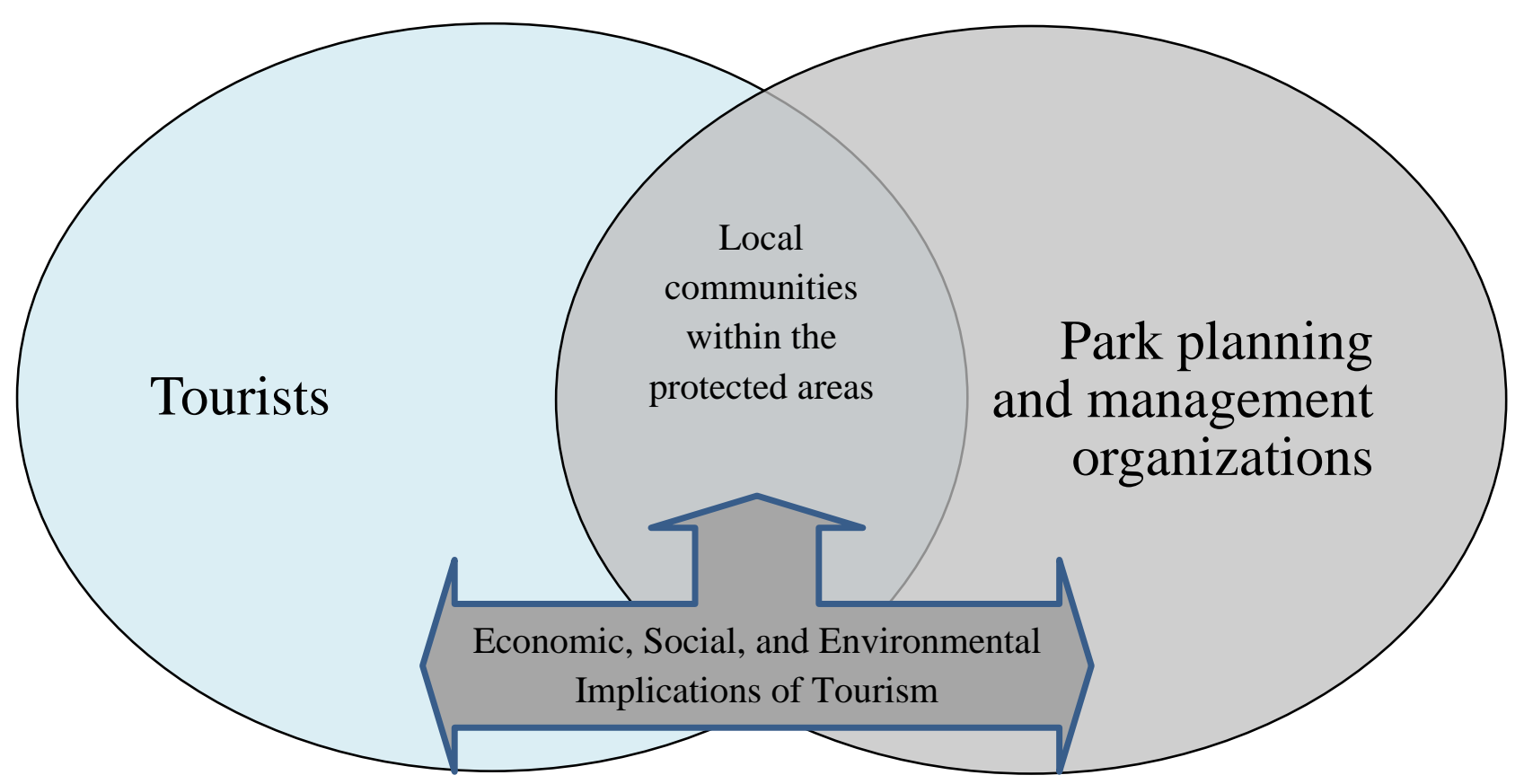

Figure 2 Objective 1 indicating the intersection of tourists and park planning and management organizations at the junction of the protected areas and the communities within those areas.

Data for research objective one are based on personal interviews with tourists and key stakeholders representing the PPMO for the protected areas, fieldwork, and secondary data sources. 
The second research objective is to determine vulnerable regions in the protected areas within a tourism context to support planning and decision-making by the PPMO. Research objective two is addressed by using GIS to conduct an overlay analysis. Once the specific layers are selected, informed by the findings obtained from the first objective, they are overlaid in a GIS and the vulnerable areas are subsequently determined. Results from each objective can then be interpreted to address how sustainable tourism development in protected areas can act as a driver for environmental conservation and community support in the region of Lake Izabal-Rio Dulce in Guatemala.

\subsection{Composition of the Thesis}

A review of the literature and existing knowledge base on sustainable tourism development in general and in Guatemala is presented in Chapter 2. Chapter 3, Methods, details the research design and the procedures with respect to data collection and analysis. Chapter 4 presents the findings from the data analysis as well as the areas of vulnerability generated from the GIS overlay analysis. In Chapter 5, a discussion on the significance of the findings based on knowledge established in the literature is given in order to form connections to sustainable tourism development in Izabal. Recommendations are also provided, along with contributions and further research, a summary of results, and conclusion that aim to highlight the contribution of the research and how it may be beneficial to tourism researchers and other stakeholders in sustainable tourism planning and management fields. 


\section{Chapter 2}

\section{Literature Review}

\subsection{Introduction}

The literature review covers Guatemala's profile in terms of its geographical location followed by the development of its tourism industry, examining the nation's popular tourist destinations and efforts to improve sustainability from a historical standpoint to its current state. The concept of sustainability is briefly explored as well as its introduction within the tourism industry. Several definitions of sustainable tourism are examined to demonstrate the difficulties in utilizing the definitions to guide tourism operation and management.

The subject of protected areas and its significance in processes of biodiversity conservation and environmental protection, as well as the influence policy decisions have had in generating conflicts with communities and people living in such areas are reviewed. Different forms of achieving sustainable tourism and associated challenges in meeting such goals are examined through international case studies. Such forms have included mitigating governance conflicts, improving community development, or addressing economic and environmental impacts. Case studies also aid in demonstrating the successes and failures that sustainable tourism development has had in general and in Guatemala. Attention is given to cases that involve tourism in protected areas as it relates to the themes of the research.

Finally, the use of GIS and its resulting analyses have been documented as having the potential to aid tourism management and decision making through the integration of qualitative and quantitative data. The literature review delves into case studies that involve the use of GIS for tourism means in both developed and developing countries, particularly focusing on the methods 
of application, successes, and failures of GIS. The methods of application include the way in which data were gathered and the key steps applied to produce relevant outcomes. This serves to provide clarity and justification for the use of an overlay analysis. Moreover, the case studies demonstrate the efficacy of GIS in tourism.

\subsection{The Republic of Guatemala}

Guatemala is a low-to-middle income, developing country with an estimated population of 14.7 million (INE, 2013). Approximately $60 \%$ of the population live in rural areas, most of which are inhabited by indigenous peoples and represent a large portion of the population (Crispín et al., 2012). Moreover, $75 \%$ of residents live below the poverty line, making living conditions bleak for rural indigenous communities and Guatemala as a whole, one of the poorest countries in the Western Hemisphere (Lyon, 2013).

The country is bordered by Mexico, Belize, Honduras, and El Salvador, with the Pacific Ocean to the south and the Caribbean Sea to the northeast (see Figure 3). Guatemala is divided into 22 departments, each with its own boundaries and municipalities. While the land is small in terms of area, the range of geographical regions that the country covers allows Guatemala to encompass unique features from different environments. The region known as Caribbean Guatemala, named for its geographical location and environmental conditions, comprises the department of Izabal (Crispín et al., 2012). The unique features of the natural landscape, such as the inland fresh water bodies of Lake Izabal and Rio Dulce, as well as protected areas are resources that may potentially allow the country to reposition itself in the international tourism market with a higher status than it has now (Crispín et al., 2012). 


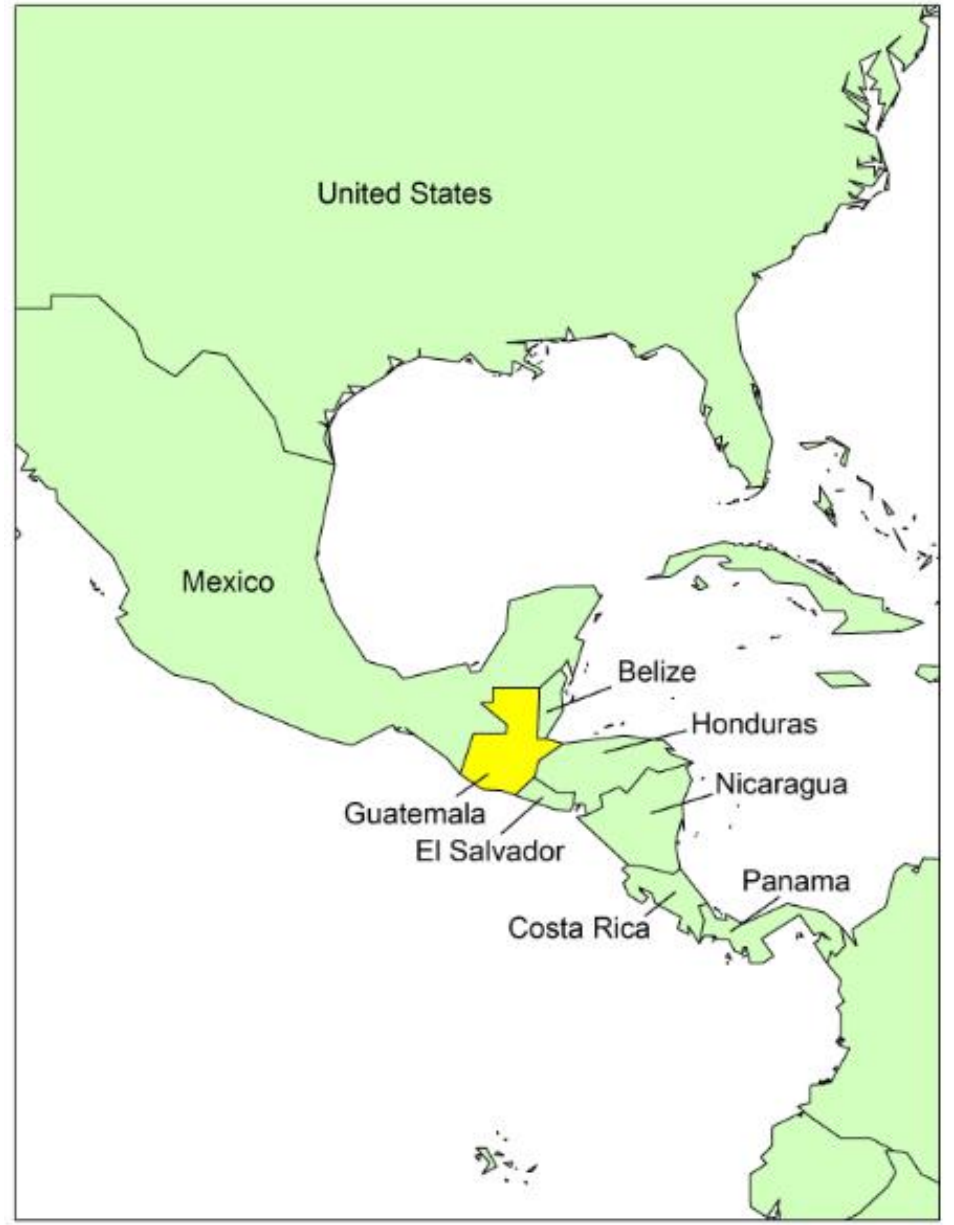

Figure 3 Guatemala's location within Central America with neighbouring countries labeled.

\subsection{The Development of Tourism in Guatemala}

Tourism in Guatemala remains the second largest contributor to the economy after coffee production (European Commission, 2007; Lyon, 2013; Yáñez-Arancibia et al., 1999). In 2011, tourism generated USD 1.3 billion from over 1.8 million tourist arrivals (Lyon, 2013). Even more recently, between January and May 2013, tourism in Guatemala grew significantly, generating an estimated revenue of USD 600 million, a $6.3 \%$ increase from the same period in 2012 (Muñoz, 2013). These figures indicate that Guatemala has had success in establishing itself as an important tourist destination. 
At the national level, the body overseeing the country's tourism development is the Guatemalan Institute of Tourism, or INGUAT (Instituto Guatemalteco de Turismo). Its current mission is to "promote and encourage the development of sustainable tourism in Guatemala at the national and international level through the coordination of public, private, and civil society sectors" (INGUAT, n.d). The National Council of Protected Areas, or CONAP (Consejo Nacional de Areas Protegidas), is another governmental stakeholder that works with other institutions, such as INGUAT, to ensure the conservation of biological diversity and sustainable use of protected areas, taking into account social and economic development (CONAP, n.d). The Chamber of Tourism of Guatemala is another governing body that represents the private tourism sector and promotes business development in order to achieve sustainable tourism (CAMTUR, n.d).

Based on the mission statements of the three main governmental bodies for tourism, there is a recognized need to develop sustainable tourism in order to position Guatemala as a premier, competitive destination based on its comparative advantages, such as Mayan ruins and abundant biodiversity. Despite the mission statements adopted by these governing bodies, government action and support remains slow-moving. For instance, the president of the Chamber of Tourism stated that the Government of Guatemala has yet to pass legislation that would strengthen INGUAT to make its governing powers more effective (Muñoz, 2013). This would provide INGUAT with the ability to increase its effectiveness in producing reliable statistical data that may serve to improve tourism promotion avenues (Muñoz, 2013). Guatemala's continued lack of support to protected areas (Hearne \& Santos, 2005) and the uneven distribution of popular tourism sites (Crispín et al., 2012) warrants a closer examination of the history of Guatemala's tourism industry to its current state. 


\subsubsection{Historical Influences on Tourism}

Over the past 50 years, Latin America and the Caribbean have become increasingly popular destinations for tourists, particularly from the United States and Europe (Wilson \& Ypeij, 2012). Guatemala followed suit by focusing on the construction and improvement of infrastructure. In the mid to late 1950s, the United States collaborated with Guatemala to improve the highways through Central America in hopes of strengthening national security, opening markets, and stimulating tourism (Streeter, 1999). As well, between 1954 and 1960, the U.S. provided Guatemala with more than USD 100 million in economic aid in hopes of stimulating foreign investment and macroeconomic growth (Streeter, 1999). What resulted, however, was an uneven distribution of profits, mostly benefiting the local elite and multinational corporations (Streeter, 1999). The political and social landscape of Guatemala soon shifted into one of conflict, resulting in a civil war that lasted for almost 40 years (Steinberg \& Taylor, 2003).

The development assistance programs funded by the U.S. in the 1950s widened the gap between the poor and the rich and alienated the indigenous population (Streeter, 1999). Community development programmes did little to improve lives and the growth of export agriculture resulted in a growth of poverty, forcing rural inhabitants to relocate or become migrant labourers (Streeter, 1999). In addition, tourism was not a significant economic generator due to political unrest and local strife during the civil war in Guatemala between 1960 to the mid 1990s, obscuring tourist activities and its promotion as well as impacting several aspects of life for the citizens of the country (Berger, 1997; Crispín et al., 2012; Moreno \& Littrell, 2001). 
The 1980s saw an increase in the degradation of the environment as military-dominated politics supported natural resource extraction for export and deforestation as a result of mining and oil drilling (Berger, 1997). Consequently, the ecological improvement of Guatemala became a low priority for policy making and natural resources such as the Petén Itza Lake became unsuitable for sustaining populations that had been living around the lake (Berger, 1997). The Peace Accords, signed in 1996, brought an end to the civil war and re-established renewed investment in several sectors of the economy, one of those being tourism (Crispín et al., 2012). Hence, the resurgence of the tourism secctor in Guatemala is recent and not as developed as other sectors.

\subsubsection{Contemporary State of Tourism in Guatemala}

The impact of the civil war can be seen today in postwar Guatemala. In the municipality of Ixcán for instance, located in western Guatemala, tourists are not allowed to take photographs of the outposts or of the soldiers who continue to maintain a significant presence in the region (Steinberg \& Taylor, 2003). While this is not true for all places in Guatemala, the postwar climate of the nation has allowed a handful of places to develop more rapidly than others within a tourism context, resulting in few major centers of tourism activity. The city of Antigua has had success in re-establishing visitation to mass-tourism levels since the height of the civil war and remains a popular destination within Guatemala (Moreno \& Littrell, 2001). Flores, which is the closest city to Tikal, and Guatemala City have also maintained strong tourism receipts owing to well-established avenues of infrastructure and accessibility (Crispín et al., 2012).

Aside from the already mentioned destinations of Tikal, Guatemala City, and Antigua, Crispín et al. (2012) found that Lake Atitlan and Chichicastenango are also heavily-promoted destinations. 
Lake Atitlan is promoted for its lake and scenic views while Chichicastenango is visited for the bustling and colourful marketplace. Figure 4 below shows the location of these major centres of tourism, which are all located in southern Guatemala with the exception of Flores. Panajachel and Flores are included in the maps because they are the main receiving towns for tourists to Lake Atitlan and Tikal, respectively. Furthermore, areas like Izabal, located in northeast Guatemala, are given less attention and are therefore less frequented by tour operators. Figure 4 also shows the boundaries of Guatemala's 22 departments.

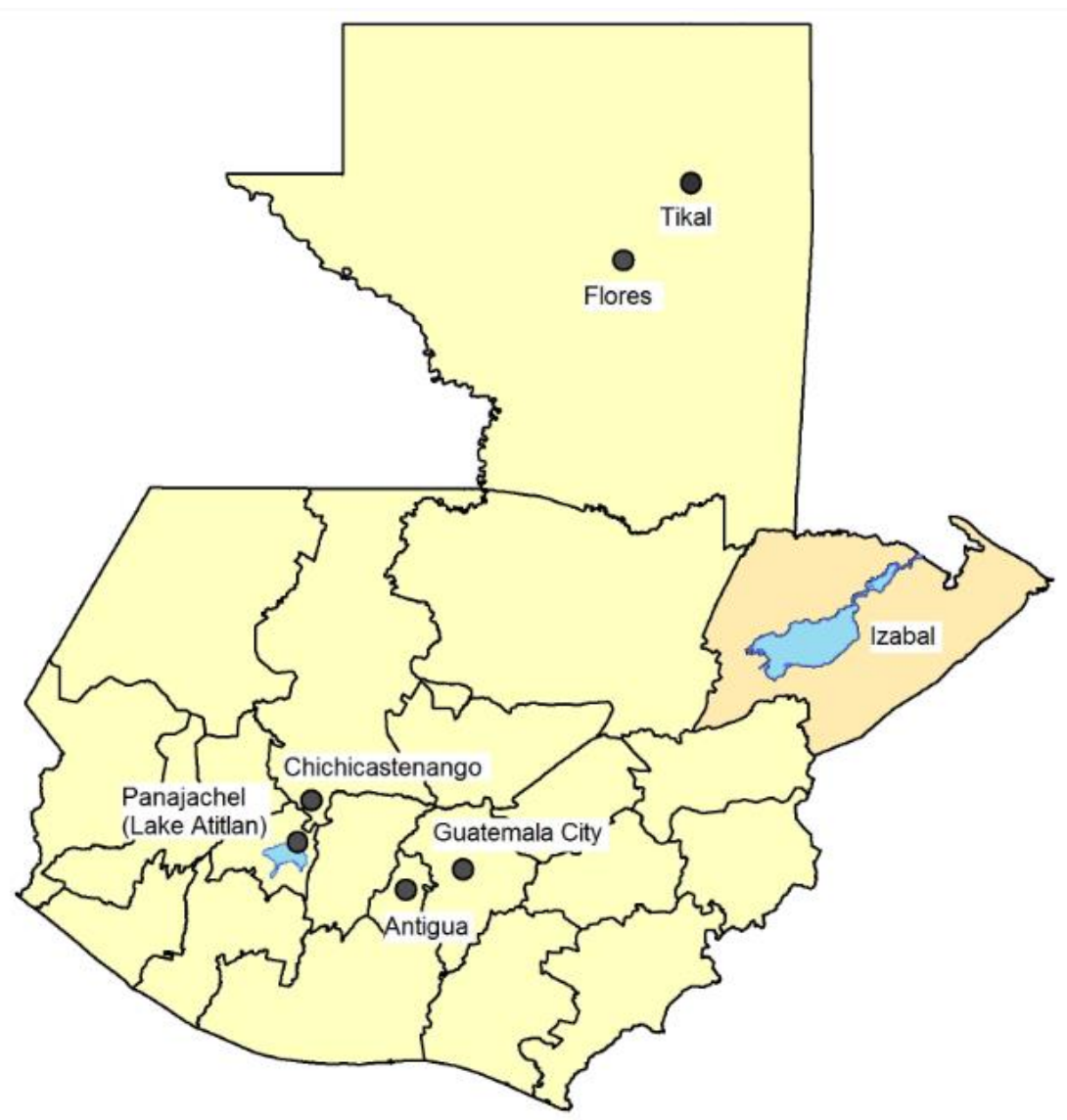

Figure 4 Map of Guatemala's main tourist destinations. 
Tourism remains largely undeveloped outside of the main tourism centers in terms of the establishment of proper infrastructure and visitation mechanisms to manage tourism arrivals. The lack of management practices in the Maya Biosphere Reserve in Northern Guatemala have continued to hamper tourism development goals that include nature conservation and public participation despite the considerable support provided by international donors and NGOs (Hearne \& Santos, 2005). The Reserve also lacks infrastructure and services; entrance fees are not collected, access to the Reserve is not monitored, lodging and guide services are lacking, and while ecotourism promotion is a stated priority, income generation for the local population is not (Hearne \& Santos, 2005). This situation has important implications for cultural centres within the reserve, with the most notable being Tikal. Additionally, the lack of development serves to undermine the purpose of the parks within the Reserve, including Tikal National Park, which was established in order to protect both natural and cultural heritage, including rare species such as the kit fox (Vulpes macrotis) and ocellated turkey (Meleagris ocellata) (Eagles et al., 2002).

\subsubsection{Tourism in the Department of Izabal}

The potential for tourism growth is noteworthy for areas that do not experience many tourist arrivals within Guatemala, as increasing the number of visitors to a specific area can aid in capturing much needed economic benefits (Eagles et al., 2002). Such is the case for tourism in the department of Izabal, which as demonstrated in the work of Crispin et al., (2012), has the potential for growth due to its geographical location and marketing as Caribbean Guatemala. Lake Izabal, the largest lake in Guatemala, discharges into Rio Dulce, which is also located within the department and passes through important tourism and commercial sites, and eventually widens into the Caribbean Sea (Binimelis et al., 2007). 
The Caribbean region of Guatemala is also important for economic activities such as the production of commercial crops (e.g., banana), cattle-raising, fishing, and providing maritime transport services (Binimelis et al., 2007; Medina et al., 2008). Mangrove swamps, rainforests, Ceiba trees, jaguars (Panthera onca), manatees (Trichechus manatus), and the golden mantled howler monkey (Alouatta palliata palliate) are some of the flora and fauna that can be found along the shores of Lake Izabal and Rio Dulce (Perlack et al., 2001). Thus, the Lake Izabal ecosystem and its main tributary Rio Dulce are important for their ecological significance, acting as a habitat for a diverse range of wildlife species (Medina et al., 2008).

Although its natural resource abundance is recognized, the few protected areas located here, namely the Rio Dulce National Park (RDNP), the Chocon Machacas Biotope, a manatee preserve, and Cerro San Gil, a water protection preserve, may not necessarily be managed in a sustainable manner (Perlack et al., 2001). Moreover, practices relating to the intensive, extractive, and unsustainable use of Guatemala's natural resources, including wildlife, have increased environmental degradation (European Commission, 2007). Such issues have demonstrated their impact on tourism development within the country.

Deforestation along Guatemala's Caribbean coast, for instance, is having detrimental effects on not only the flora and fauna of the region, but also on important tourist activities, particularly bird watching (Valladares, 2012). Deforestation rates for Izabal have been high compared to the rest of the country, particularly for periods of 1991 to 2001 and 2006 to 2010 (Valladares, 2012). Studies on protected areas that have ecotourism, conservation activities such as monitoring, and 
good relations with the surrounding communities have been shown to be effective in reducing deforestation (Vuohelainen, Coad, Marthews, Malhi, \& Killeen, 2012).

The sustainable management of Guatemala's resources is important as it has the potential to improve water supply and increase economic development, particularly in rural areas where poverty is highly concentrated (European Commission, 2007). Yet, it is often the case that in developing countries, tourism policies are outdated, and attractions, such as natural parks, do not have management and land use plans (Geneletti \& Dawa, 2009). In Izabal, the Authority for the Sustainable Management of Rio Dulce Watershed (AMASURLI), a government organization that plays an important role in coordinating and regulating tourism, is not recognized by all other stakeholders in this region, suggesting a lack of coordination amongst agencies (Binimelis et al., 2007). The lack of coordination and policies have implications for the management of tourism and natural resources for the protected areas in the Lake Izabal-Rio Dulce region. Thus, there is a need to develop tourism in a sustainable manner, since tourism has the potential to secure longterm benefits for local economies and infrastructure (Ólafsdóttir \& Runnström, 2009).

\subsection{Sustainability and Sustainable Development}

The notion of sustainability originated within the context of renewable resources such as fisheries or forests (Lélé, 1991). Sustainability and sustainable development were subsequently adopted into the environmental discourse and used interchangeably with the terms "ecologically sustainable" or "environmentally sound development" (de Vries \& Petersen, 2009; Lélé, 1991). Initially, however, sustainability focused on establishing an ecologically or environmentally desired target and measuring this target through the use of an indicator, assessing the difference between what was accomplished and the pre-industrial natural state (de Vries \& Petersen, 2009). 
Thus, the scope of sustainability remained narrow. In the late 1980s to early 1990s, social scientists and economists made it clear that sustainable development could not be based solely on ecological and environmental criteria (de Vries \& Petersen, 2009).

Sustainable development policy milestones emerged in the 1960s, owing to the worsening ecological and socio-economic conditions that were triggered a decade earlier, as well as concerns of toxic pollution and the rising world population (Quental, Lourenço, \& da Silva, 2011). The concept of sustainable development gained prominence within the environmental arena in the 1980s, which led to a plethora of definitions as an attempt to provide a guiding principle for the world community (de Vries \& Petersen, 2009). It was not until the publication of the Brundtland Report Our Common Future in 1987, however, that the notion of sustainable development gained wide acceptance (de Vries \& Petersen, 2009; Quental et al., 2011).

The Brundtland Report provided a seemingly all-encompassing definition of sustainable development, one that is defined as development that "meets the needs of the present without compromising the ability of future generations to meet their own needs" (WCED, 1987). Represented in the definition is a concern regarding aggregate human impacts, their threat to future generations, and that sustainability requires a modification to human society (Buckley, 2012). Our Common Future remains a critical milestone within several contexts of development and interdisciplinary fields because it raised important considerations regarding humanenvironment relationships (Sneddon, Howarth, \& Norgaard, 2006). While the definition of sustainability remains vague, it has become widely accepted as a starting point for those 
concerned with environmental and developmental problems and is the most commonly cited within sustainability literature (Quental et al., 2011; Sneddon et al., 2006).

\subsubsection{Sustainability in Tourism}

Efforts to achieve sustainability in the tourism industry grew out of the need to avoid adverse socioeconomic and environmental impacts caused by tourism (Torres-Delgado \& Palomeque, 2012). Environmental aspects did not play a major role in tourism for consumers and suppliers during the build-up of mass tourism from the mid-1960s to the early 1980s (Peters \& Weiermair, 2002), which contributed to negative environmental impacts. Much like the origin of sustainability in a general developmental context, the notion of sustainability in the tourism industry began with a focus on environmental conservation (Torres-Delgado \& Palomeque, 2012). Nonetheless, moving towards sustainability in tourism proved challenging owing to increased levels of ecological degradation, inequalities in economic opportunities across societies, and fractured institutional environmental governance (Sneddon et al., 2006).

The frameworks of the early to mid-1990s and the transformation to sustainability that occurred within tourism created approaches that were extremely "tourism-centric" and therefore became partially disconnected from the main objectives of sustainability (Diamantis \& Ladkin, 1999). The ambiguity in the definition of "sustainable" also presented itself as an obstacle, criticized for

producing excess theory and formulation that has had little practical application (Torres-Delgado \& Palomeque, 2012). This view is not new as previous authors have made the assertion that it is difficult to determine whether new policies of sustainability will indeed create environmentally 
and socially meaningful forms of development (Lélé, 1991). Thus, the vagueness of the term has been criticized as not being suitable for operational purposes (Campagna, 2006).

Developing indicators is often proposed by policy-makers and academics to make sustainable tourism a more operational and concrete concept (Tanguay, Rajaonson, \& Therrien, 2013). Such is the case in an industry that has no common management frameworks or indicators that allow the tracking and monitoring of changes, such as socio-economic changes within tourism (Choi \& Sirakaya, 2006). Indicators provide the necessary specificity that can guide the management of tourism by measuring progress towards the achievement of specific goals and objectives (Eagles et al., 2002). Hence, indicators are increasingly viewed as an important component of destination planning and protected areas management as well as a fundamental element for the advancement of sustainable development within the tourism sector at all scales (WTO, 2004). Examples of environmental and socio-economic indicators are given in section 2.5.

Nonetheless, due to its varying and sometimes contradictory definitions, defining a system of governance based on the notion of sustainable development has been difficult to accomplish and has impacted tourism in a number of ways, resulting in limited to isolated examples of sustainable initiatives or improvements within tourism (Holden, 2009). Nature-based and wilderness tourism market niches, among others, emerged as a response to develop sustainable frameworks to manage and plan tourism (Diamantis \& Ladkin, 1999). Examples of these initiatives are explored in sections 2.6.1 and 2.6.2, focusing on community-based tourism, propoor tourism, nature-based tourism, and ecotourism within protected areas. The successes and 
failures of developing sustainable tourism are contrasted to note the gaps in protected area planning and management initiatives in developing countries.

\subsection{Tourism in Parks and Protected Areas}

Parks and protected areas are important in the development of sustainable tourism, as they not only serve to maintain some of the world's most important ecosystems, habitats, and species, but also are important cultural places for people to visit in order to contemplate and understand the natural world (Eagles et al., 2013). The continuous demand for tourist activities in natural environments influences the promotion of protected areas as attractive and marketable settings for these demands (Eagles et al., 2002). Thus, park managers and planners face a dual mission in that the protection of key natural and cultural assets, which motivated the creation of the protected area in the first place, must be observed while accommodating those who make use of those assets (WTO, 2004).

Protected areas have had a long history, with some historians claiming India as an early pioneer when areas were designated for the protection of natural resources over two millennia ago (Eagles et al., 2002). Since then, there has been a tremendous growth in the number of protected areas. Figure 5 shows this growth as a percentage of terrestrial area for the years 1990, 2000, and 2010, and is categorized into developed regions, developing regions, and overall global trends. In the developed world, protected areas grew from $9.2 \%$ in 1990 to $13.9 \%$ in 2010 in terms of area covered (UNEP-WCMC, 2013). Protected areas in developing regions grew from 8.6\% in 1990 to $14.6 \%$ in 2010 , a much wider range of growth when compared to developed regions (UNEPWCMC, 2013). 


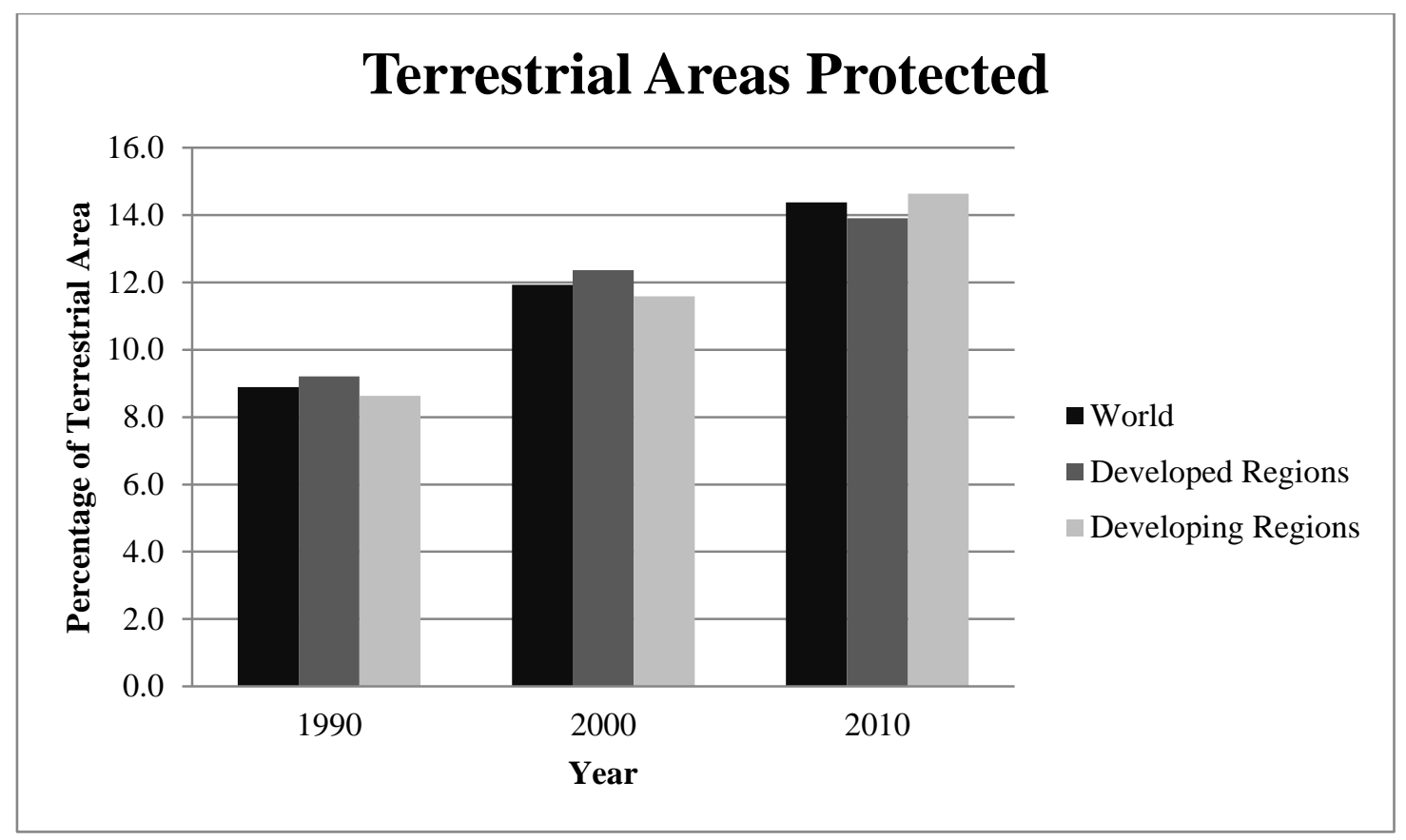

Figure 5 Growth in protected areas from 1990 to 2010 by percentage of terrestrial area. Adapted from UNEP-WCMC (2013).

Tourism within protected areas produces potential benefits by enhancing economic opportunities, protecting the natural and cultural heritage of a destination, and enhancing the overall quality of life, though the relationships often interact in complex ways (Eagles et al., 2002). Both Buckley (2002) and Eagles et al. (2002) assert that protected areas are for conservation first, in order to preserve some type of biophysical process or condition, such as a natural landscape, wildlife, or cultural heritage and tradition. Since these areas have been studied for their value on the physical, mental, and emotional well-being of individuals (Buckley, 2002), recreation is agreed to be the secondary purpose of protected areas (Buckley, 2002; Eagles et al., 2002). Hence, the planning and management of these areas are important because they reflect, to varying degrees, aspects related to social, economic, and environmental pillars of sustainable development. 
In developing countries, issues regarding tourism development exist for a number of reasons, such as poorly managed protected areas, impoverished rural populations, inequitable land and resource concentration, and uncontrolled resource extraction (Bonham et al., 2008). In Guatemala, for example, the protected areas management system is similarly modelled to that of international conservation organizations, but due to a lack of formal management on the ground, conserving biodiversity has yet to be effectively managed (Bonham et al., 2008).

Developing an understanding of major issues related to sustainable tourism and economic impacts in developing countries requires the design and implementation of management systems capable of bringing together tourism and scientific knowledge (Tremblay, Pearson, \& Gorman, 2008). The following subsections present themes related to the management of tourism within protected areas, examining aspects of organizations and their level of involvement in such areas, conservation management, community development, and income generation.

\subsubsection{Organizational Management and Collaboration}

Issues of decentralization, decision-making, and in a broader sense the issue of governance, affect how protected areas are managed (Dearden et al., 2005). Designing policy, economic decision making, and administrative procedures that implement law and policy are interdependent (Eagles et al., 2013). As such, sustainable tourism development and planning should take on a decentralized framework that defines sustainable tourism, reorganizes skill sets, and promotes collaboration among the varying stakeholders (Vellas, 2002). Decision-making and developmental processes should involve multiple stakeholders at all levels of planning, bringing together governments, NGOs, local residents, property owners (whether they are residents or 
not), and industry (Choi \& Sirakaya, 2006; Timur \& Getz, 2009). This coming together of stakeholders is important as fractured governance has proven to be an obstacle towards sustainable development (Sneddon et al., 2006).

Cooperation with stakeholder groups and improving relationships between government bodies are challenges that need to be addressed in order to effectively govern protected areas and tourism (Dearden et al., 2005). For instance, the agency AMASURLI in Izabal, despite being a governmental organization, lacks the human resources and financial support to manage Lake Izabal (Binimelis et al., 2007). Because of this, its role in regulating tourism in the region is not recognized by other stakeholders (Binimelis et al., 2007). Promoting collaborative efforts between agencies who manage the protected areas and government bodies related to tourism and environmental management serves as a strategy to address challenges of governance in such areas (Dearden et al., 2005).

In protected areas with established restrictions (e.g. area restrictions), those who own property may receive the economic consequences of such restrictions (Gonzalez, Gonzalez, Polome, \& Prada, 2002). Ownership of property and resources has four categories: 1) government agency; 2) not-for-profit institution; 3) for-profit corporation; and 4) community (Eagles et al., 2013). The varying ownership possibilities have implications on leasing tourism operating rights on shared land tenure, which may or may not contribute to biodiversity conservation and community well-being (Buckley, 2012). Factors that need to be considered include the cohesion, structure, and internal governance of organizations within a protected area (Buckley, 2012). To overcome such issues, Eagles et al. (2002) propose several guidelines for shared ownership of 
resources that encourages stakeholder participation through meetings and workshops, and shared responsibilities of tasks.

\subsubsection{Managing Conservation}

A method to meet conservation goals for properly managed tourism in protected areas is to give biodiversity a direct economic value, and therefore capitalize on such assets, should the area contain such assets (Tremblay et al., 2008). One example comes from Rwanda's Parc National des Volcans, where demand for gorilla viewing was high enough to impose a fee of almost USD 200 per person (Eagles et al., 2002). This allowed conservation activities to be funded for various protected areas in Rwanda (Eagles et al., 2002). Conservation plans that include economic benefits from biological diversity can potentially be used to determine areas that can profit more from conservation than other alternative land uses (Di Minin et al., 2013). Furthermore, it has also been found that, in general, the value of a site for nature-based tourism or ecotourism purposes increases as the quality or quantity of the environmental attributes of that site increases (Di Minin et al., 2013).

In addition, Freytag and Vietze (2013) have demonstrated empirically that sustainable tourism development benefits from the richness of biodiversity but is negatively impacted by biodiversity loss. Such a loss can occur in a number of ways. In a study by Collins-Kreiner et al. (2013), it was demonstrated that an increase in visitor group size has a detrimental impact on both visitor experience and wildlife conservation because it was found to decrease the number of birds in a given location, subsequently impacting the goals of bird watchers and related birding activity. Mozmuder, Berrens, and Bohara (2006) utilized a risk index to arrive at a similar finding 
whereby an increase in tourism arrivals translated to an increase in risk of biodiveristy loss, although the relationship was descibed as "relatively mild." Tools to manage this include limiting group size, imposing area closures, or limiting length of stay (Eagles et al., 2002).

Environmental indicators are essential to conservation and sustainable tourism planning (Tanguay et al., 2013; Vellas, 2002). Biodiversity and ecosystem vulnerability indicators are important in implementing tourism amenity policies in fragile areas and it has been recommended to contain the following (Vellas, 2002): fauna - number of species, populations of species, size of habit for species, decrease in habitat size; and flora - number of species, populations of species, share of primitive flora, size of habit for species, decrease in habitat size. Other environmental indicators that may also be taken into account include waste treatment and water consumption (Vellas, 2002).

Intricate links are made among biodiversity and the development of sustainable tourism, economic growth, and the conservation of nature (Freytag \& Vietze, 2013). Although, like many forms of development, tourism will continuously produce environmental impacts and tourism in protected areas is no exception (Eagles et al., 2002). Buckley (2012) asserts that it is erroneous simply to consider that environmental protection increases with economic growth as economic prosperity must also include cultural, historical, and socioeconomic values, particularly in developing countries. This is complicated for countries that lack the resources to facilitate compromise between conservation and varying land uses (Di Minin et al., 2013). 


\subsubsection{Communities in Protected Areas}

Tourism and environmental conservation are not solely dependent on biodiversity, as securing long term environmentally-improved tourism services can be best achieved through human investments within the context of environmental management as well as through quality improvements in alliance networks or inter-firm cooperation (Peters \& Weiermair, 2002). Communities, either within or at the periphery of a protected area, present unique issues in the relationship the communities have with the protected area (WTO, 2004). Cases involving tourism to Lake Atitlan, Guatemala or Santa Catalina, Panama, while not directly related to protected areas, have demonstrated that the increased population of communities has led to an increased pressure on natural resources and hindered cooperation (Drumm, 2013; Wallace \& Diamente, 2005). Improving cooperation amongst stakeholders should also include community participation in order to improve the management of protected areas (Dearden et al., 2005).

Conflict is at times present between advocates for protected areas and defenders of human rights because of an underlying model that tends to posit nature as separate from humans, which has previously led to the exclusion of former inhabitants from the access and use of land in protected areas as well as in decision making (Kitamura \& Clapp, 2013). This occurs especially for indigenous people, who are often already economically and politically disadvantaged (Kitamura \& Clapp, 2013). Moreover, the lack of clearly defined property rights within the protected area may impede the protection of user's present or future interests (Gonzalez et al., 2002). This has been cited as one of Guatemala's main problems, resulting in rapid urban growth and the proliferation of informal settlements (Badurek, 2009). 
Land occupation indicators are essential in planning for sustainable tourism within vulnerable areas because it directly relates to load capacity (Vellas, 2002). Vellas (2002) outlines two main criteria to measure land occupation, one which takes into account the ratio of tourists to residents and the other a ratio of tourism infrastructure to total surface area. Such an indicator should also include a component of communities, particularly if tourism is being developed in protected areas with human presence. Other criteria, as outlined by the WTO (2004), involve measuring the participation of the communities in stakeholder meetings and number of violations as it relates to the management of protected areas. Community participation as an indicator is important because it has been recognized as a driver for improving governance within protected areas, and hence the planning and management of those areas (Dearden et al., 2005). Moreover, socio-economic impacts caused by tourism should be addressed in sustainable development planning, as tourism generates problems pertaining to changing lifestyles, rising living costs, or increasing crime rates (WTO, 2004; Vellas, 2002).

\subsubsection{Income Generation and Visitor Management}

Securing funding is important as it has implications on how the area is managed, which has increasingly moved away from government-based funding to tourism-based fees (Eagles et al., 2013). According to Eagles et al. (2013), there are three main income sources for managing protected areas: 1) societal fees, often used in developed countries; 2) user fees and charges, the main source in developing countries; and 3) donations, sometimes utilized as a secondary source of income. Visitor fees are also important for achieving several management objectives other than generating income, such as decreasing use, managing use based on an alternative area or time, and creating an attitude of respect for the area (Eagles et al., 2002). 
Visitor fees and any associated rates and applicability (e.g. fees for children versus adults), however, usually attract social, economic, and legal arguments that may be for or against this type of management method (Buckley, 2002). Introducing, or increasing user fees, for a natural attraction may lead to an exclusion of low-income groups who cannot afford to pay such fees and hence restricts their participation (Reynisdottir, Song, \& Agrusa, 2008). This has been the case for the Inca Trail, where the increase in fees for hiking left Peruvians priced out from experiencing their own natural and cultural heritage (Maxwell, 2012). Some areas use a twotiered fee system or differential pricing that makes foreigners pay more than residents, the goal being to encourage residents or a less privileged sector of society to utilize protected areas and minimize socio-economical discriminatory effects (Eagles et al., 2002; Reynisdottir et al., 2008).

In some countries, visitor fees contribute significantly to management costs, with over $50 \%$ of funding allocated to protected area management, although the norm remains around $10 \%$ and in other countries the rate stands at zero (Buckley, 2012). The implications of such figures are of concern for improperly managed areas because potential revenue is lost. While some areas may have controlled entrance points, where fees are collected and the number of entrants is monitored, most protected areas have limited control and this is particularly the case for areas with multiple entrances or inhabitants within the area (WTO, 2004). To manage such occurrences, some common approaches to management and conservation have included setting buffer areas with restricted access to the public, signposting, merging service infrastructure, and creating trails to prevent uncontrolled dispersal of visitors (Collins-Kreiner et al., 2013). 


\subsection{Successes and Failures of Sustainable Tourism}

Select case studies of sustainable tourism development in other countries are discussed in this section because they inform how goals to achieve sustainability have been carried out and the successes and failures these cases have had. Moreover, the case studies demonstrate sustainability in action and allow connections to be made with the frameworks of sustainability that are applied in each case. In other words, they allow judgments to be made about what elements were considered when carrying out the objectives. Alongside these cases, several forms of tourism are briefly examined as they exist to capture fragments of sustainability but cater to a specific group of tourists or individuals (i.e. market). The forms of tourism briefly examined here are pro-poor tourism, community-based tourism, nature-based tourism, and ecotourism. It should be noted, however, that these niches are not necessarily mutually exclusive.

\subsubsection{Community-based and Pro-poor Tourism}

Tourism niches such as community-based tourism (CBT) and pro-poor tourism are important because of their aim to create a more sustainable tourism industry (Harrison, 2008; Salazar, 2012). CBT focuses on communities as the destination within a tourism planning and developmental context, with the anticipated benefit of generating income and employment opportunities for the communities (Salazar, 2012). Pro-poor tourism on the other hand can be defined as tourism that brings net benefits to the poor by unlocking opportunities for these groups within tourism (Harrison, 2008).

An example of the successful incorporation of sustainability in tourism can be seen in a case study in Ruhija, Uganda, conducted by MacKay and Campbell (2012). It was shown that the 
establishment of Gorilla Friends Tented Camp, a village community located adjacent to a gorilla habitat, had success in generating visitors and revenue for a community that previously had no tourist accommodations and few opportunities for locals to earn income (MacKay \& Campbell, 2012). This was accomplished by following principles of local participation and linking existing systems to establish a viable and sustainable destination (MacKay \& Campbell, 2012).

Although the efforts to implement sustainable tourism are considered successful, continued viability of the campsite in Ruhija, as found from tourist interviews, requires national partnership networks in order to support local community tourism initiatives, such as information distribution and improved accessibility (MacKay \& Campbell, 2012). An example of the importance of partnership networks can be found in Tanzania. In 1995, a CBT project launched by the Dutch agency Stichting Nederlandse Vrijwilligers (SNV) saw the establishment of a successful tourism venture for a network of local communities offering individual tour packages, which included tours of natural heritage and cultural attractions (Salazar, 2012). In 2001, however, the SNV withdrew from the program, which resulted in decreased cooperation between participating communities, an uneven distribution of revenues, and the disintegration of the Tanzania Cultural Tourism Organization (Salazar, 2012).

Pro-poor tourism is circumscribed in the notion of economic growth as a foundation for development (Hall \& Page, 2009). The community of Bario, Sarawak in Malaysia embraced propoor tourism as a means to generate income through several avenues of adventure ecotourism and cultural tourism, and were able to foster local economic and societal reinvigoration (Harris, 2009). The e-Bario Knowledge Fair was established as a pro-poor tourism initiative that sought 
to showcase how the indigenous community of Bario appropriated information and communication technologies, particularly with access to computers with internet access (Harris, 2009). Rural villagers allowed visitors to stay in their households and share in their daily lifestyles, which in this study was argued as an implementation of community-based tourism and pro-poor tourism, as the former is considered to be a form of the latter (Harris, 2009).

While the relationships between tourism and poverty reduction are noted, there is a tendency for approaches in pro-poor tourism to overlook environmental, social, and political issues (Hall \& Page, 2009). Buckley (2012) also states that differences in prosperity and poverty should include considerations of culture and equity, which are made more complex when such differences in equity are found within communities in less developed nations. Pro-poor tourism, as seen in the Bario example, relies on and must be a part of wider tourism systems, and should include access to tourism markets, policy support for secure investments to develop tourism, and stakeholder cooperation (Harrison, 2008).

Issues remain in that government attitudes in developing countries, such as Guatemala, have constrained the poor, uneducated, and indigenous people's ability to be effective political agents of change and so their participation in decision making processes is often challenged (Badurek, 2009). This may also occur within communities, whereby the emergence of local elites may produce inequalities and result in conflicting interests (Salazar, 2012). Community engagement, empowerment, and collaboration can aid in addressing the aforementioned issues (Okazaki, 2008; Salazar, 2012). 


\subsubsection{Nature-based Tourism and Ecotourism}

Nature-based tourism is one that centers on natural attractions, such as landscapes, wildlife, ecosystems, rivers, and lakes, or outdoor activities, and a desire to experience it within a reasonable amount of comfort (Eagles et al., 2002; WTO \& UNEP, 2008). This type of tourism is supported in rural and protected areas because of its potential to have a positive impact on the economy, leading to regional development (Reinius, 2011). Much like the previous forms, this tourism niche is not without its criticisms. Nature-based tourism, unlike ecotourism, has been criticized for lacking a conservation component (Diamantis \& Ladkin, 1999). In addition, a precise definition of nature-based tourism does not exist, as this tourism niche is sometimes used interchangeably with "green tourism," "alternative tourism," and "ecotourism" (Diamantis \& Ladkin, 1999; Hopkins \& Price, 2002). Furthermore, negative impacts to the environment due to climate change and other factors will adversely affect this type of tourism, primarily in parks and protected areas (WTO \& UNEP, 2008).

The concept of ecotourism, a tourism niche which emerged in the late 1980s, was enhanced by the gradual shift towards planning in protected areas and potential employment opportunities in natural areas (Diamantis \& Ladkin, 1999). Ecotourism is a form of nature-based, low-impact tourism that provides opportunities for income generation and supports nature conservation by creating an economic demand for natural ecosystems (Hearne \& Santos, 2005). It involves a willingness to experience nature with few comforts (Eagles et al., 2002). Several studies have identified three core features of ecotourism: natural attractions, which may incorporate elements of culture and heritage; educational experiences and opportunities; and planning and management that maximize environmental and socio-cultural sustainability (Collins-Kreiner et 
al., 2013). Hence, ecotourism has been distinguished from nature-based tourism by its close associations to sustainable tourism (Hopkins \& Price, 2002).

Ecotourism in Podocarpus National Park in Ecuador is utilized as a strategy for economic development in the region the park is located in and to establish the park as a sustainable protected area (Moran-Cahusac, 2009). The park was found to be improperly managed as private tour operators had developed their own tourism products with little or no consultation with Ecuador's Ministry of the Environment (Moran-Cahusac, 2009). During a visit to a tourist attraction at the edge of the park, Moran-Cahusac (2009) found that the trail had no tourist activity, was abandoned and looted by local communities, and no maintenance scheme had been developed. The trend of low visitor numbers to the park, however, was seen as advantageous because it offered stakeholders an opportunity to determine and address the gaps in tourist product development, as well as in the regulation and implementation of ecotourism projects (Moran-Cahusac, 2009). Using this advantage and successfully developing sustainable tourism, however, is dependent on the central government's political support (Moran-Cahusac, 2009).

The Inca Trail in Peru, which is traversed by thousands of trekkers through natural environments to reach the archeological site of Machu Picchu, suffered from environmental impacts caused by increased trail use, trash, and human waste during the mid-1990s (Maxwell, 2012). In order to address these issues, state agencies created protected areas in the region to protect biodiversity (Maxwell, 2012). Due to a chronic persistence of weak and fiscally-challenged state agencies, however, the parks required external funding and management interventions which essentially converted them to "paper parks" (Maxwell, 2012). Paper parks are protected areas with little to 
no on-the-ground management and therefore fail to achieve the goal of biodiversity conservation (Bonham et al., 2008).

Ecotourism on the Inca Trail became a term to denote conservation and tourism planning, yet the trail was never managed under ecotourism frameworks (Maxwell, 2012). To combat the environmental impacts, policies were created that required trekkers and tour agencies to hold permits, the carrying capacity of the trail was limited to 500 people per day, and tour prices increased from $\$ 80$ per person to $\$ 420-500$ per person (Maxwell, 2012). The Inca Trail case is an example of the influence negative environmental impacts have on officials towards driving social and environmental change in Latin America (Maxwell, 2012). The importance that state intervention has on the management of tourism and environmental conservation is also seen.

\subsection{Sustainable Tourism in Guatemala}

This section presents examples of sustainable tourism ventures in natural areas in Guatemala in order to provide an insight into the contemporary development of tourism and themes of community development. Beginning with Chisec, Alta Verapaz, located in central Guatemala, the administration and success of an ecotourism venture involving several lagoons was hindered by business-related legalization processes under Guatemalan law, as well as the use of the lagoons as communal washing sites for over 200 families (Smith \& Ley, 2009). As Smith and

Ley (2009) point out, the use of lagoons as washing sites resulted in significant amounts of pollution from soaps and bleach chemicals. Through collaboration with community members, a Guatemalan sustainable development organization, and the United States Peace Corps, artificial wetlands were constructed as a means to treat the polluted waters (Smith \& Ley, 2009). Not only 
did this enhance the environmental state of the lagoons but it also enhanced the health and economic status of community members (Smith \& Ley, 2009).

A Lake Atitlan ecotourism study conducted by Wallace and Diamente (2005) indicated that tourism was undeveloped owing to a disinterest by The Nature Conservancy (TNC) on local concepts of ecology and a lack of attention paid to negative tourist impacts. In an assessment of viable ecotourism projects in the area of Lake Atitlan, located in Southwest Guatemala and commissioned by TNC, it was found that TNC assumed that the local residents were the main threats to the biodiversity of the region (Wallace \& Diamente, 2005), hence their focus shifted to the impacts caused by local people. This suggests then, that Lake Atitlan, albeit a well-marketed and well-visited tourist area (Crispín et al., 2012), should be better managed to accommodate ecotourism projects. The study carried out by Wallace and Diamente (2005) showed that by applying an anthropological lens, conservation projects designed mainly to aid wildlife rather than local communities have negative economic effects. In addition, recommendations made in the study pushed to ensure the inclusion of a fundamental component of ecotourism development: the local people (Wallace \& Diamente, 2005).

Paper parks, protected areas termed for their little to no on-the-ground management, fail to achieve the goal of biodiversity conservation (Bonham et al., 2008). The Sierra Chinaja, a protected area located in northwest Guatemala, has experienced significant threat due to land invasion from permanent settlers from surrounding communities (Bonham et al., 2008). Issues of land tenure security have placed residents in a position that does not allow them to invest in long-term management of the land and so must resort to unsustainable practices involving short 
rotation agricultural cropping systems (Bonham et al., 2008). Furthermore, residents are unable to participate in alternative forms of livelihoods such as ecotourism (Bonham et al., 2008). To alleviate these issues, Bonham et al. (2008) suggest several management strategies, particularly focusing on the establishment of an indigenous reserve and placing a certain level of responsibilities in the hands of community members with continued governmental support.

\subsection{The Use of Geographic Information Systems in Tourism}

Geographic information systems (GIS) have great potential in the planning and management of sustainable tourism infrastructure (Boers \& Cottrell, 2007). GIS can be described as an information system technology that is used to store, retrieve, manipulate, analyse, and present geographical data in a spatial context (Chhetri \& Arrowsmith, 2008). Tourism stands to benefit from GIS analyses because of its ability to be used for a variety of tourism applications related to planning and management, such as tourism resource inventories, the identification of suitable tourism locations, and assessing potential impacts of tourism (Bahaire \& Elliott-White, 1999).

GIS facilitates the decision making process by incorporating various forms of data, such as environmental (topography, slopes, vegetation, and water bodies), infrastructure (roads and amenities), and socioeconomic data, thereby bringing together tourism and scientific knowledge (Hall \& Page, 2009). What results is the production of informed arguments that ideally facilitate compromise and resolution to a problem (Bahaire \& Elliott-White, 1999). GIS has been utilized in a number of locations for sustainable tourism development, particularly in parks and protected areas, such as the Sinharaja Forest Reserve in Sri Lanka (Boers \& Cottrell, 2007), Vatnajökull 
National Park in Iceland (Ólafsdóttir \& Runnström, 2009), and the Grampians National Park in Australia (Chhetri \& Arrowsmith, 2008).

Due to the spatial nature of environmental problems in tourism, GIS has been favoured within environmental applications to analyze alternative uses that compete for space (Campagna, 2006). This competition for space is evident in tourism planning as it not only pertains to infrastructure development (e.g. hotels and amenities) and surrounding land uses, but also in defining services and activities in which space is contested by multiple entities, such as trekkers and wildlife on a specific trail. Spatially assessing recreation and tourism usually involves four general approaches: 1) mapping visitor expenditures per unit of space; 2) mapping potential recreation areas based on the amount of natural and semi-natural habitat and accessibility measured by its proximity to population centres and major roads; 3) mapping benefits received from tourism based on the transfer of finances from a location to the site under evaluation; and 4) engaging stakeholders in order to map recreation and landscape values (Nahuelhual, Carmona, Lozada, Jaramillo, \& Aguayo, 2013). When conducting spatial conservation prioritization analysis, it is important to include data on vulnerability of significant biological features from current or future threats (Di Minin et al., 2013).

\subsubsection{Overlay Analysis}

In order to justify the use of overlay analysis for this study and in the GIS case studies described in this section, a brief history of the development of this method is presented. The invention of the layer model and the concept of ecological planning are widely credited to Ian McHarg, who in his 1969 book Design with Nature, utilized semi-transparent map overlays to mask sensitive 
areas while suitable areas remained translucent (Rinner \& Düren, 2011). Thus, because of its importance to GIS in establishing an overlay methodological process, McHarg's method has been considered the gold standard of sustainable land use planning and is utilized in several studies pertaining to tourism development (McGehee, et al., 2013).

An early example of the use of overlay within a GIS came from Gunn (1994), who used GIS to identify locations with the greatest potential for tourism growth in South Carolina, USA. Gunn (1994) identified these locations by delineating areas based on natural and cultural resources, taking into account water bodies, vegetation, wildlife, topography, existing natural and cultural resources, historical sites, cities, and transportation routes. Through an overlay analysis, the results showed that significant tourism development was already in place and that the area had the ability to compete well with other regions in South Carolina (Gunn, 1994). In this case, however, Gunn (1994) did not consider potential environmental impacts.

McGehee et al. (2013) used the overlay analysis approach to aid in the determination of the tourism potential in the Appalachian mountains of Virginia, USA. Utilizing agricultural heritage features, scenic vistas and natural areas, as identified through stakeholder interviews, visitor surveys, and GPS visitor tracking, seven tourism scenarios were developed that could potentially encourage visitor expenditures while maintaining the environment and quality of life for the surrounding communities (McGehee, et al., 2013). The example shows that this method remains common among researchers (Gunn, 1994; Boers \& Cottrell, 2007; Tremblay et al., 2008). 


\subsubsection{Case Studies in GIS}

In a more recent study conducted in Western Victoria, Australia, GIS was used to determine zones with great scenic appeal in order to attract a greater number of visitors to the Grampians National Park (Chhetri \& Arrowsmith, 2008). In order to define the attractiveness of scenic vistas, several attributes were identified by Chhetri and Arrowsmith (2008) based on the available literature and, in doing so, the data collected included elevation, slope diversity (i.e. slope variation and the total number of slopes per square kilometer), relative relief (i.e. variation of vertical elevation), water proximity, and vegetation variety. The attributes were given standardized scores within a GIS and using a "neighbourhood function," which takes into account measurements of density and distance, attractive areas of the park were delineated (Chhetri \& Arrowsmith, 2008).

In a study conducted by Boers and Cottrell (2007) in Sri Lanka's Sinharaja Forest Reserve (SFR), GIS was used to map sustainable trail development locations by overlaying visitor preference maps and carrying capacity indicator maps. Visitor preferences and suitable indicators were determined through personal observations, informal stakeholder interviews and on-site surveys (Boers \& Cottrell, 2007). Since the data were not collected to reflect tourism infrastructure planning, the data quality was limited and so the case study served to demonstrate a comprehensive approach for planning sustainable tourism trails in protected areas rather than to make recommendations (Boers \& Cottrell, 2007).

Geneletti and Dawa (2009) assessed the impacts of trekking on trails in Ladakh, a region in the Indian Himalaya, by mapping existing dumpsites, campsites, soils, off-road tracks, grasslands, 
and groundwater and surface water bodies, all of which undergo stress due to trail use, animal grazing, waste dumping, and off-road driving. To accomplish this, the study area was subdivided into smaller watershed units and assigned an average impact value (Geneletti \& Dawa, 2009). In order to cope with the lack of data for the region under study, remote sensing imagery was used (Geneletti \& Dawa, 2009). The maps were then aggregated to represent impacts at the watershed level in order to improve the visualization of the impact of trekking and enhance the readability of the results (Geneletti \& Dawa, 2009). As deemed by Geneletti and Dawa (2009), watersheds represent meaningful units of ecological processes and land-use management.

The aforementioned cases demonstrate that GIS is useful in identifying spaces that may serve to increase revenue through increased visitor numbers. However, the use of GIS for environmental management has also become prominent in tourism planning. In Costa Rica, for instance, GISbased siting has been referred to as a useful tool in determining the appropriate location of hotel properties for destinations with fragile ecosystems (Joerger, DeGloria, \& Noden, 1999). Joerger et al. (1999) examined soil data to determine the suitability of land for construction as well as sites appropriate for on-site wastewater management. Moreover, in order to avoid new road construction, which has the tendency to cause environmental degradation, potential hotel sites were chosen based on their proximity to existing roads and highways (Joerger et al., 1999).

A case study in southeastern Iceland looked to GIS as a decision support system to aid in the selection of suitable land that avoided areas with moss cover in order to advance the development of sustainable tourism (Ólafsdóttir \& Runnström, 2009). Ólafsdóttir and Runnström (2009) categorized slope angles, soil types, and vegetation cover into sensitivity classes, ranging 
from 0 , being no sensitivity, to 3 , being the highest sensitivity. The objective of the study was to address environmental degradation due to trampling and erosion (Ólafsdóttir \& Runnström, 2009). Addressed in the study were future GIS-based research endeavours that make use of tourist statistics and field studies in order to model tourist choices and attractions (Ólafsdóttir \& Runnström, 2009).

Sustainable tourism development in protected areas is an attractive venture because of their function in not only conserving biodiversity, but also in providing a setting for outdoor activities. Planning and managing tourism within these areas, however, presents various problems. Community-based tourism and nature-based tourism niches have emerged as solutions to the vague notion of sustainability and to produce coherent operational and management frameworks. Issues of governance, community development, visitor management, and income generation remain as obstacles towards sustainable development because these issues intersect societal, economic, and environmental pillars. GIS, because of its ability in integrate qualitative and quantitative data, serves as a useful tool to determine tourism impacts in sensitive spaces. Indicators as a management and planning tool, used in conjunction with GIS, can serve to facilitate decision-making processes by targeting problematic areas related to sustainability.

In Guatemala, issues of fractured governance, improperly managed protected areas, uneven distribution of tourism arrivals, and environmental degradation have impeded the development of sustainable tourism. Such problems have stalled environmental conservation and community development for areas seeking alternative livelihoods. Regions with an abundance of biodiversity have been found to provide opportunities for tourism. As gathered in the literature, solutions 
involving improved stakeholder collaboration, community participation, and the creation and implementation of policies are viewed in a positive light that serve to improve the management of tourism within protected areas. 


\section{Chapter 3}

\section{Methods}

\subsection{Introduction}

This chapter outlines the research design rationale. The methods of collecting and analyzing data are also explained, and linked to the objectives of the research. Triangulation of methods and sources were utilized within the context of the multi-method case study approach. The Lake Izabal-Rio Dulce region is discussed in greater detail as the study area for the research, including the timeframe during which fieldwork took place and the protected areas studied, as well as the tourism services and products offered at these areas. The scope and limitations of the methods are also discussed in this section, touching upon the case study, data collection methods, and data usage issues.

\subsection{Multi-method Case Study Design}

The approach taken for this study was a multi-method, research-based case study. A case study is a holistic empirical inquiry that allows the researcher to gain an in-depth understanding of a contemporary phenomenon by utilizing multiple sources of evidence (Beeton, 2005). The case study, which has also been described as illuminative and information rich (Patton, 2002), is wellsuited to developing an understanding of the contemporary development of sustainable tourism in Guatemala as a means for environmental protection and community development. In particular, it is useful in addressing the research purpose to inform sustainable tourism development from multiple perspectives. 
The multi-method approach in the case study stems from the use of multiple sources of evidence in the research in order to help inform the analysis and the subsequent results. Adopting a multimethod, or mixed-method approach, has become increasing popular with field researchers (Bonham et al., 2008; Lew, 2011; MacKay \& Campbell, 2004; Nahuelhual et al., 2013; Salazar, 2012). This is not only because a multi-method approach addresses more than one research epistemology, such as observation and reasoning, but also because such a method results in both a greater understanding of the breadth of the problem and opportunities to report different perspectives on the obtained data (Lew, 2011).

Bonham et al. (2008), together with an interdisciplinary team of researchers, collected biophysical, socioeconomic, and land use data in order to identify potential management plans for the protected area of Sierra Chinaja, Guatemala. Nahuelhual et al. (2013) assembled a GIS database using multiple sources in a case study of ecotourism and recreation mapping in Southern Chile. Reinius (2011), in her study of protected areas in Sweden, utilized a multimethod approach by combining quantitative and qualitative methods through on-site observations, interviews, and statistical data. MacKay and Campbell (2004) showed that using biophysical and sociocultural research methods in a systematic manner can expand traditional assessment models and trail impact monitoring.

In this case study, triangulation is an important component of the research design. The multimethod approach allows the use of multiple sources of evidence in order to examine sustainable tourism development around Lake Izabal and Rio Dulce. These sources are primary and secondary, and involve both quantitative and qualitative data, collected using a combination of 
on-site fieldwork and observations, interviews, and document analysis (Patton, 2002). Qualitative methods in tourism fieldwork are more commonly applied to research that addresses tourism impacts or attitudes among local people and in this case the perspectives that may or may not influence impacts and attitudes (Reinius, 2011). Quantitative methods involve the use of statistical information to supplement the findings. The use of GIS is also a component of the design for the completion of the second objective and makes use of data collected from interviews for the determination of data layers. Documents, particularly park plans, are used to cross-check park specifications. Table 1 summarizes the data collection methods. It shows the specific method, source, timeframe, and main focus of that method.

Table 1 Data collection

\begin{tabular}{|c|c|c|c|}
\hline Method & Source(s) & Timeframe & Main Focus \\
\hline $\begin{array}{l}\text { Fieldwork - on-site } \\
\text { observations }\end{array}$ & Protected area visits & $\begin{array}{l}\text { July } 11,2013- \\
\text { August 2, } 2013\end{array}$ & $\begin{array}{l}\text { Construct case study, } \\
\text { observe workings of } \\
\text { management and } \\
\text { tourist interaction } \\
\text { with environment }\end{array}$ \\
\hline Interviews & $\begin{array}{l}\text { Tourists and key } \\
\text { stakeholders in } \\
\text { planning/management } \\
\text { organizations }\end{array}$ & $\begin{array}{l}\text { July } 2013 \text { \& January } \\
2014\end{array}$ & $\begin{array}{l}\text { Determine } \\
\text { perspectives of } \\
\text { tourists and } \\
\text { stakeholders }\end{array}$ \\
\hline $\begin{array}{l}\text { Secondary sources } \\
\text { and document } \\
\text { analysis }\end{array}$ & $\begin{array}{l}\text { Park plans for the } \\
\text { protected areas in the } \\
\text { study. Tourism } \\
\text { statistics from } \\
\text { government sources }\end{array}$ & May 2013 - Present & $\begin{array}{l}\text { Cross-check } \\
\text { interviews, compare } \\
\text { perspectives, and } \\
\text { gauge development } \\
\text { progress }\end{array}$ \\
\hline GIS overlay analysis & $\begin{array}{l}\text { NREL, interview } \\
\text { results }\end{array}$ & $\begin{array}{l}\text { August } 2013- \\
\text { January } 2014\end{array}$ & $\begin{array}{l}\text { Determine zones of } \\
\text { vulnerability within } \\
\text { the protected areas }\end{array}$ \\
\hline
\end{tabular}




\subsection{Study Area}

The study took place in the department of Izabal, Guatemala, which is located in the northeast part of the country, in what is known as Caribbean Guatemala. Contained within the department is Lake Izabal, Guatemala's largest lake, which connects to Rio Dulce thereby forming the lakeriver system, and flows out to the Caribbean Sea. Figure 6 shows a map of the department of Izabal in relation to Guatemala. The climate greatly influences the area's landscapes and biological diversity. As stated previously, the Lake Izabal ecosystem (Figure 6) plays an important role as a habitat for numerous wildlife species as well as for food, transportation, and biodiversity conservation (Medina et al., 2008).

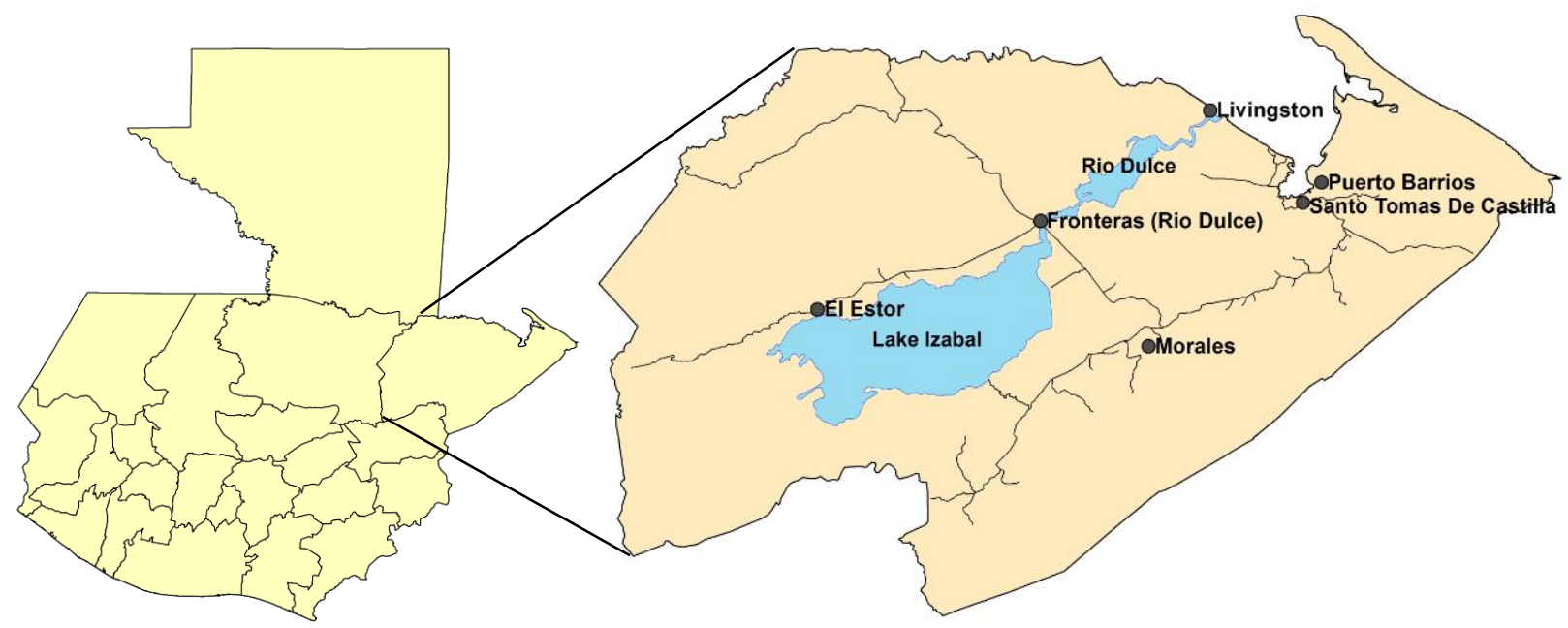

Figure 6 Map of Izabal, major roadways and towns, and the Lake Izabal-Rio Dulce system.

Figure 6 also depicts some of the larger towns in Izabal, located along the roadways that run through Izabal. Livingston is the only town on this map not located next to a major road network. The case study involves three protected areas in the vicinity of the Lake Izabal-Rio Dulce system. The protected areas are: Cerro San Gil, Rio Dulce National Park, and Chocon Machacas 
(Figure 7). As per the objectives, these areas were selected for the examination of sustainable tourism development, environmental conservation, and community development. Figure 7 also shows the location of Campo Dos, the location of temporary stay for the duration of fieldwork in Izabal.

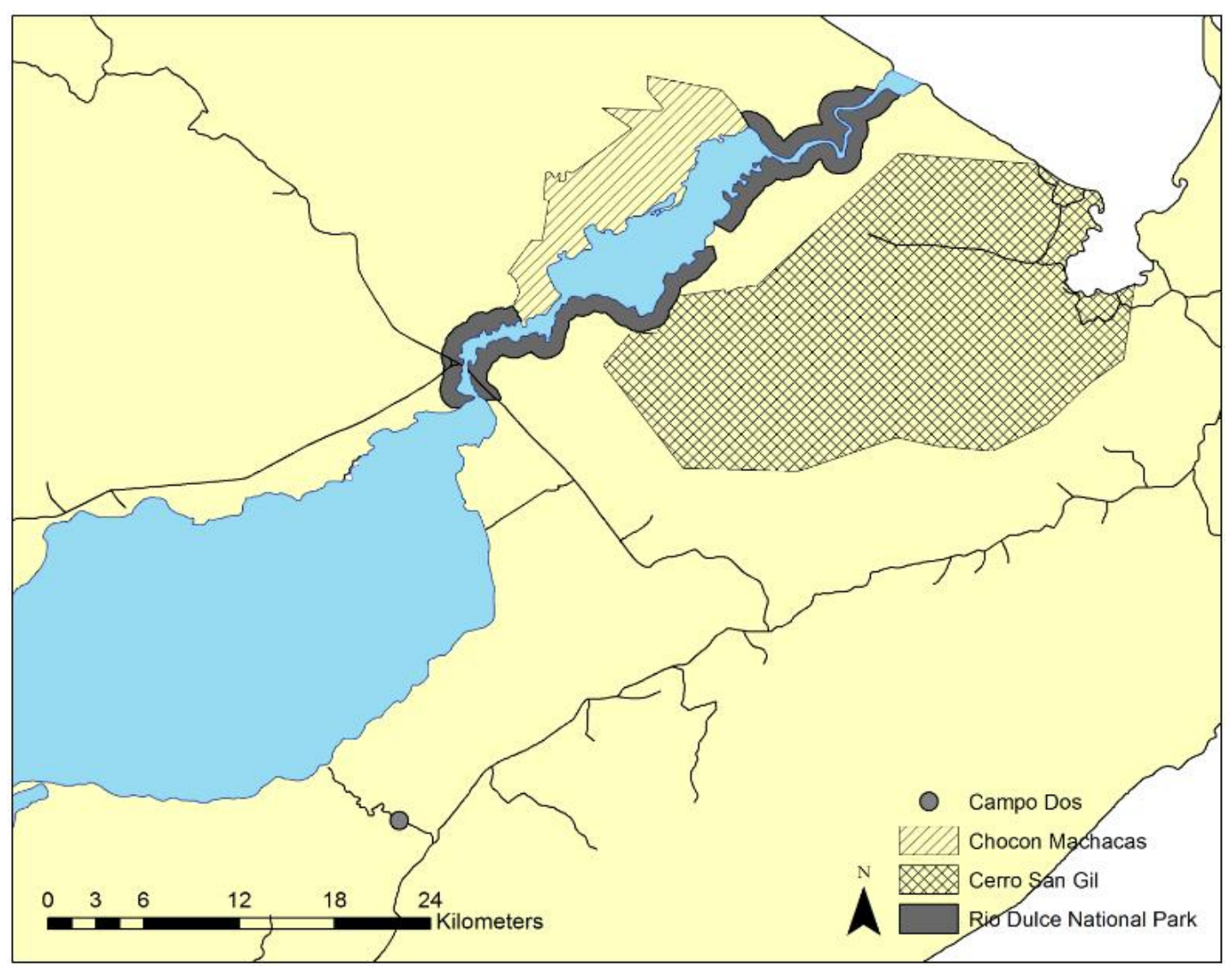

Figure 7 Map of the protected areas, including location of temporary stay (Campo Dos).

These sites were selected based on their proximity to the Lake Izabal-Rio Dulce system, where Rio Dulce National Park and Chocon Machacas are adjacent to the river and Cerro San Gil is adjacent to the national park (Figure 7). The proximities of the sites to each other make them accessible by road and marine transport, which aided in facilitating movement between these 
sites. Moreover, the relative connectivity of these three protected areas is of importance because they are recognized as forming a corridor for the movement of species within the region (CONAP \& FONACON, 2004). This has implications for the number of species observed and recorded in the protected areas.

Campo Dos (Figure 7) served as the place of residence for the duration of fieldwork. This also made Lake Izabal readily accessible. Daytrips to the various sites required at least one hour of travel time to reach the nearest protected area. For instance, Rio Dulce at Las Fronteras is located an hour away while the eastern region of Cerro San Gil is located approximately two hours away. Chocon Machacas is accessible by boat from Rio Dulce and required at least another hour to access. On the contrary, Lake Izabal was only 20 to 30 minutes away, which allowed for multiple trips to collect data. The closest town located by the lake is Mariscos, which was also visited in order to observe the town's infrastructure, particularly hotels, restaurants, and other tourist amenities.

The planning and management organizations responsible for the operation of the protected areas are given in Table 2. Rio Dulce National Park is managed by CONAP and Cerro San Gil by the Foundation for Ecodevelopment and Conservation (FUNDAECO), a NGO (SEGEPLAN, 2011). Chocon Machacas is mainly managed by CONAP and partly by a university-based organization known as CECON-USAC since there is some considerable geographical and administrative overlap with Rio Dulce National Park (CONAP \& FONACON, 2004). The protected areas under study in Izabal, their designated category of protection, size in hectares, and date of declaration are also described in Table 2. 
Table 2 List of protected areas examined in this study. Adapted from CONAP (2013)

\begin{tabular}{llllll}
\hline $\begin{array}{l}\text { Protected } \\
\text { Area }\end{array}$ & $\begin{array}{l}\text { Management } \\
\text { Category }\end{array}$ & $\begin{array}{l}\text { Category } \\
\text { Type }\end{array}$ & $\begin{array}{l}\text { Size in Area } \\
\text { (Hectares) }\end{array}$ & $\begin{array}{l}\text { Date } \\
\text { Declared } \\
\text { Protected }\end{array}$ & $\begin{array}{l}\text { Management } \\
\text { Organization }\end{array}$ \\
\hline Rio Dulce & National Park & Type I & 13,000 & 1955 & CONAP \\
$\begin{array}{l}\text { Chocon } \\
\text { Machacas }\end{array}$ & $\begin{array}{l}\text { Protected } \\
\text { Biotope }\end{array}$ & Type II & 6,265 & 1990 & $\begin{array}{l}\text { CONAP/ } \\
\text { CECON - } \\
\text { USAC }\end{array}$ \\
$\begin{array}{l}\text { Cerro San } \\
\text { Gil }\end{array}$ & $\begin{array}{l}\text { Natural Spring } \\
\text { Protection } \\
\text { Reserve }\end{array}$ & Type III & 47,433 & 1996 & FUNDAECO \\
& & & & & \\
\hline
\end{tabular}

The category type is a classification schema developed by the Guatemalan Protected Areas System (SIGAP), where type I is a national park, managed mainly for ecosystem and landscape protection, type II is a protected biotope managed mainly for natural features for areas of smaller size, and type III is categorized as a spring water protection reserve, managed mainly for the conservation of specific natural features (SIGAP, 2013). The classification is intended to serve as a guide for the management and planning of the protected areas. Descriptions of each of the protected areas are described in the following sections.

\subsubsection{Rio Dulce National Park}

The national park is accessed via the Central American highway CA-9 in Guatemala and the town of Las Fronteras as the main receiving town for tourists (SIGAP, 2013). This town is reached by crossing the bridge that allows travellers to go over the river, with one side of the bridge facing Lake Izabal and the other facing the national park and Rio Dulce (Figure 6). Due to its strategic location as a thoroughfare for traffic, tourists, and commercial goods en route to 
Petén, Guatemala, several services can be found here, including banks, hotels, restaurants, and general shops (CONAP \& FONACON, 2004). Several boats can be seen stationed along the shores and establishments (i.e. hotels and restaurants) of Rio Dulce. Most of the boats seen here belong to retirees from different countries and are privately owned.

Rainforest, wetlands, marshes, and mangroves can be seen on both sides of the river. A few sites of interest are scattered throughout the park. A small piece of land located at the beginning of the park, on the river, contains various bird species perched on trees that appear to rise out of the water. San Filipe Castle is another main point of interest as it is a historical site located within the protected area, accessible from Las Fronteras through local roads and from the river. Communities of various population sizes are scattered throughout the protected area (CONAP \& FONACON, 2004). The national park comes to an end at the town of Livingston (Figure 6).

\subsubsection{Chocon Machacas}

Chocon Machacas is located midway through Rio Dulce National Park, on one side of the river (Figure 7). It is also located along the shores of Rio Dulce and extends inland. Due to its location, features of the protected area are similar to that of RDNP along the shores of the river and hence contains wetlands, rainforests, and mangroves (Ixcot Yon, 2005). Further inland, however, the elevation of the area influences the cover of the land, which is described as tropical, humid forest cover (Ixcot Yon, 2005). The protected area is accessible from the river by boat or through small roads from the northern part of Chocon Machacas. Moreover, much like RDNP, the area contains few inhabited communities in restricted areas (Ixcot Yon, 2005). 


\subsubsection{Cerro San Gil}

Cerro San Gil is named as a "cerro," which translates to hill or high land. Thus, it is located on a hill that covers a large area in northeastern Izabal and has an influence on the physical landscape of the protected area. The closest towns to Cerro San Gil in the northeast are Santo Tomas de Castilla and Puerto Barrios (Figure 6) (CONAP, FUNDAECO, \& TNC, 2006). Santo Tomas de Castilla is a port town, receiving tourists and cargo while Puerto Barrios is a neighbouring, much larger town. Various services can be found in these two towns ranging from restaurants, lodging, banks, and small shops. The opposite end of Cerro San Gil can be accessed via small roads, with small communities, in terms of population, found throughout that end (CONAP et al., 2006).

Cerro San Gil is distinct from the other two protected areas in the Lake Izabal-Rio Dulce region because it contains natural spring water sources that act as a source of drinking water for communities within and outside of the protected area, and as a tourist attraction (CONAP et al., 2006). The natural abundance of the area in terms of its natural features (e.g., forests, creeks, and small waterfalls) serves as a habitat for various species of birds, amphibians, and mammals, including the jaguar (CONAP et al., 2006). Las Escobas and Green Cove serve as entrance points to the protected area as well as sites that allow tourists to partake in swimming activities, boat rides, and wildlife viewing opportunities within Cerro San Gil (FUNDAECO, 2011).

\subsection{Secondary Sources and Document Analysis}

Secondary source document analysis was conducted prior to fieldwork in order to reveal initiatives or issues within Izabal and the protected areas not specifically dealt with in the research literature. Specific secondary sources utilized were master park plans, documents from 
governmental sources (e.g. INGUAT and CONAP), and local news reports. News reports were examined for information relevant to current environmental and tourism issues within Izabal and more precisely the protected areas. These sources served as additional support in terms of gauging the level of action being taken by the government or of public awareness of environmental issues.

To determine the available tourism services and facilities offered at the protected areas, online websites, specifically the Guatemalan Protected Areas System, were consulted to extract information about what is already offered at these areas. This was conducted prior to fieldwork and the information obtained was used to guide location and content selection for tourist interviews. It also gave an indication of infrastructure, service expectations, and potential observations at the sites during fieldwork. A list of tourism activities, and facilities and services at the protected areas under study are found in Table 3 and Table 4.

Table 3 Tourism activities in the protected areas in Izabal. Adapted from (SIGAP, 2013)

\begin{tabular}{llllllll}
\hline $\begin{array}{l}\text { Protected } \\
\text { Area/Park }\end{array}$ & $\begin{array}{l}\text { Kayaking/ } \\
\text { Boat } \\
\text { Rides }\end{array}$ & $\begin{array}{l}\text { Bird } \\
\text { Watching }\end{array}$ & Swimming & $\begin{array}{l}\text { Hiking/ } \\
\text { Trekking }\end{array}$ & $\begin{array}{l}\text { Scuba } \\
\text { Diving/ } \\
\text { Snorkeling }\end{array}$ & $\begin{array}{l}\text { Wildlife } \\
\text { Viewing* }\end{array}$ & $\begin{array}{l}\text { Culture } \\
\text { Discovery }\end{array}$ \\
\hline $\begin{array}{l}\text { Rio Dulce } \\
\text { National }\end{array}$ & $\times$ & $\times$ & & $\times$ & $\times$ & \\
Park & & & & & \\
$\begin{array}{l}\text { Chocon } \\
\text { Machacas }\end{array}$ & $\times$ & $\times$ & $\times$ & $\times$ \\
$\begin{array}{l}\text { Cerro } \\
\text { San Gil }\end{array}$ & $\times$ & $\times$ & $\times$ & & \\
\hline
\end{tabular}

Note: An asterisk (*) signifies wildlife viewing separate from bird watching. 
Table 4 Facilities and services in the protected areas in Izabal. Adapted from (SIGAP, 2013)

\begin{tabular}{llllllllll}
\hline $\begin{array}{l}\text { Protected } \\
\text { Area/ } \\
\text { Park }\end{array}$ & Food & $\begin{array}{l}\text { Hotel/ } \\
\text { Lodge }\end{array}$ & Restroom & Trails & $\begin{array}{l}\text { Scenic } \\
\text { Viewpoint }\end{array}$ & $\begin{array}{l}\text { Local } \\
\text { Guides }\end{array}$ & $\begin{array}{l}\text { Camp } \\
\text { Grounds }\end{array}$ & $\begin{array}{l}\text { Tourist } \\
\text { Info }\end{array}$ & $\begin{array}{l}\text { Hand- } \\
\text { crafts }\end{array}$ \\
\hline $\begin{array}{l}\text { Rio Dulce } \\
\text { National }\end{array}$ & $\times$ & $\times$ & & $\times$ & $\times$ & & & \\
Park & & & & & & & & & \\
$\begin{array}{l}\text { Chocon } \\
\text { Machacas }\end{array}$ & $\times$ & $\times$ & $\times$ & $\times$ & & $\times$ & $\times$ & $\times$ \\
$\begin{array}{l}\text { Cerro } \\
\text { San Gil }\end{array}$ & $\times$ & $\times$ & $\times$ & $\times$ & & $\times$ & $\times$ & $\times$ & $\times$ \\
\hline
\end{tabular}

Cerro San Gil contains a hotel, known as the Green Bay Hotel, and an eco-lodge that also serves as the protected area's biological research station (FUNDAECO, 2011; Kekeotripz, n.d.). Chocon Machacas counts with one lodge located in a small community known as Lagunita Salvador (SIGAP, 2013). Rio Dulce National Park contains at least seven small, commerciallyoperated hotels along the stretch of the river, beginning at the town of Las Fronteras and ending at the town of Livingston (Kekeotripz, n.d.). The national park, however, does contain a greater number of accommodation sites, but are much smaller and privately owned, and have not been tallied (CONAP \& FONACON, 2004).

\subsection{Fieldwork}

Fieldwork was conducted through on-site observations and interviews at the three protected areas, which comprise a component of the multi-method case study design introduced in this chapter as part of the triangulation procedure. On-site interviews were conducted with key stakeholders, including tourists, and observations were made with respect to management practices and tourists' interaction with the environment. Fieldwork also included visits to Lake 
Izabal, the town of Mariscos, and a community considering establishing a tourist attraction based on a natural waterfall. The name of the community is withheld in order to maintain confidentiality due to a member's participation in the study.

Field notes were taken to record visits, events, and observations on a daily basis. The importance of field notes is documented by Patton (2002), who states that field notes contain insights, interpretations, and the working hypothesis regarding experiences in the field. Geneletti and Dawa (2009) note that field visits are useful in gaining a better understanding of relationships between tourists and the intensity of environmental stressors. Moreover, field notes act as a fundamental database in constructing case studies and for carrying out thematic analysis (Patton, 2002).

Field observations included, but were not limited to, the observation of infrastructure (e.g., roads, houses, tourist centres, etc.), signage, accessibility to the sites (e.g. available parking, bus access), entrance and exit points, and the overall management and planning practices in place for the areas visited, such as posted rules or hours of operation. The protected areas were observed for fee structure for local tourists versus international, cleanliness, employee interaction with tourists, available amenities such as bathrooms, rest areas and gift shops, trail maintenance, signage, and general tourist demographics. Whenever applicable, entrance vouchers or tickets were kept and any brochures or information pamphlets the park provided to tourists were obtained. 
At Lake Izabal, observations were made with respect to cleanliness at the water's edge, road access to the lake, infrastructure, and visitor demographics. Other general observations were made while travelling within Izabal and outside of the department, particularly the condition of highways and road infrastructure, effects of increased population, and areas where potential scenic lookout areas could be established.

A total of seven days were spent in Izabal, including the date of arrival to Izabal. Additionally, the work days were limited due to schedules made with respect to living arrangements in Izabal and the need to travel to Guatemala City, the capital city of the nation, located about 6 to 7 hours away, in order to access INGUAT and other potential interviewees. A total of 5 days were spent in Guatemala City prior to departure. Table 5 lists the sites visited and work conducted on specific days for the duration of stay in Izabal. 
Table 5 Schedule of areas visited and work conducted

\begin{tabular}{|c|c|}
\hline Schedule & ea Visited/Work Conducted \\
\hline Day 1: July 12, 2013 & $\begin{array}{l}\text { - Visited Santo Tomas de Castilla and Cerro San Gil, site of } \\
\text { Las Escobas. } \\
\text { - Toured the site within the protected area. } \\
\text { - Conducted interview with planner from FUNDAECO. }\end{array}$ \\
\hline Day 2: July 13, 2013 & $\begin{array}{l}\text { Visited community within Cerro San Gil and a potential } \\
\text { future tourism site down the side of a mountain, located } \\
\text { nearby a waterfall and river. } \\
\text { - Observed potential scenic vista sites of Lake Izabal prior } \\
\text { to arriving at the town of Mariscos, located by the lake. } \\
\text { - Made observations in terms of tourism infrastructure. } \\
\text { - Visited site where rubber trees are cultivated for rubber } \\
\text { and discussed its economic importance to the region. }\end{array}$ \\
\hline
\end{tabular}
Day 3: July 14, $2013 \quad$ Visited Lake Izabal in close proximity to Dorada Beach.
- Four tourist interviews were conducted at the beach.
- Additional questions were asked to determine if they had visited any one of the protected areas.

Day 4: July 15, 2013

- Visited Rio Dulce National Park and toured the river on boat, approaching Chocon Machacas.

- Visited San Filipe Castle and conducted three tourist interviews just outside the site.

- Visited El Paraiso, a natural spring/waterfall site located 30 minutes from Rio Dulce, adjacent to Lake Izabal.

\begin{tabular}{ll} 
Day 5: July 16, 2013 & $\begin{array}{l}\text { - } \\
\text { - }\end{array}$ \\
& $\begin{array}{l}\text { Conducted interview with community member involved in } \\
\text { planning processes. }\end{array}$ \\
Day 6: July 17, 2013 & - $\begin{array}{l}\text { Revisited Lake Izabal at Dorada Beach and conducted two } \\
\text { more tourist interviews. }\end{array}$ \\
\hline Last 5 days & $\begin{array}{l}\text { Travelled to Guatemala City and attempted to gain access } \\
\text { to interviewees from INGUAT and CONAP. }\end{array}$ \\
\hline
\end{tabular}




\subsection{Interviews with Key Stakeholders}

Interviews with key stakeholders involved in the management and planning of sustainable tourism in Guatemala were conducted as part of the fieldwork. The sample of key stakeholders is a non-probability sample, or a purposeful sample, which focuses on a specific set of the population due to their relevance (Bryman, Teevan, \& Bell, 2009). Purposeful sampling techniques are used in case studies because sampling is aimed at the phenomenon under study rather than empirical generalizations about a population (Patton, 2002). Tourism planners and managers who have direct associations with the protected areas in Izabal were sought. To do this, the organizations responsible for the management of the protected areas were determined (as shown in Table 2) and through website searches, publicly available contact information was obtained for potential interviewees with planning and management positions. The primary focus is on how that setting is affecting the stakeholder's perspective of tourism (Patton, 2002).

Contact was made in Spanish via electronic mail immediately after the interview guide and research protocol were approved by the Research Ethics Board, which occurred two weeks prior to the field visit. The electronic messages included the consent form and interview guide in order to give the individual an idea of what to expect for the interview. See Appendix A for a copy of the consent form in both English and Spanish. If a response was not given within a week, a phone call was made to the individual or organization using telephone numbers obtained from online sources (i.e. website of organization/protected area).

Semi-structured, in-depth interviews were conducted with key stakeholders in order to promote the standardization of questions being asked and recording of answers, as well as to gain in-depth 
information on the various practices conducted at these locations (Bryman et al., 2009). The questions were open-ended because they allowed the respondents to describe, in whatever detail they desired, what is meaningful without being immediately categorized (Patton, 2002). Since Spanish is the native language spoken in Guatemala, the interviews were conducted in Spanish unless there was a specific preference for English. Although one interviewee was able to speak English, Spanish was the preferred language for the interview. In the event that an interviewee was not available to conduct an in-person interview, a telephone interview was scheduled.

The interview guide for the key stakeholders was developed by taking the overarching question of how sustainably planned and managed tourism can potentially lead to the increased protection of national parks and protected areas around Lake Izabal, Guatemala, and breaking it down into more specific components. The opening question was intended for the interviewee to provide a perspective on Guatemala's overall current park management practices and potentially provide the first indications of issues with respect to governance in protected areas. The questions were then narrowed to query specific environmental pressures the area faces, social and economic impacts of tourism on surrounding communities, the role of the interviewee within the organization and in managing tourism, the importance of tourism to the area, and any specific framework used to make decisions. The closing questions dealt with the use of GIS and issues with data collection and analysis. See Appendix B for a copy of the interview guide in both English and Spanish.

The interviews were set to be an hour to an hour and a half in length in order to budget for any extra time needed for the interviewees. Audio tapes were used to record the interviews with key 
stakeholders and were supplemented with note taking during the interview. The audio tapes were physically protected and secured at all times in the luggage during travel and later in a safe. This was done to ensure confidentiality and privacy. The interviews were transcribed in Spanish prior to any translation. Translation of interview recordings from Spanish to English was conducted by the principal researcher followed by another person fluent in Spanish and English in order to compare the accuracy of the translations, which would also help to verify that the intended message is not lost during translation.

\subsubsection{Interviews with Tourists}

Reaching tourists and obtaining their participation can be a challenge, and one commonly used method of obtaining potential respondents is to approach them at main access points (Reinius, 2011). Convenience sampling of tourists was conducted to secure structured interviews on-site. Tourists were intercepted at exit points or just outside of the protected area, which allowed the tourist to explore as much of the area in advance of being interviewed. A potential tourist was approached at the park or protected area if they appeared to be a non-local, utilizing physical appearance, types of clothing worn (i.e. traditional clothing versus non-traditional), and personal gear (i.e., travel gear, cameras, etc.) as indicators. Two screening questions querying their main

purpose of travel to Izabal and place of origin were asked in order to confirm that indeed the person was a tourist. A consent form was also provided to tourists (see Appendix C).

The questionnaire for the tourists was designed to query specific cultural, economic, and environmental aspects that attracted them to the area, as well the most memorable feature of the area. The length of the visit was also queried, followed by their recommendations to enhance the 
area as a tourist attraction. Eight questions were asked in total. The length of time for tourist interviews was maintained to an average of five minutes and no more than ten minutes. The interviews were conducted in both Spanish and English. The responses were written down and not audio recorded. These data were analyzed to address, in part, the first objective and to gain a better understanding of tourists' purpose of travel and their views on the role protected areas play in the development of sustainable tourism. See Appendix D for the questionnaire for tourists.

The total number of stakeholder and tourist interviews conducted was 15 . Of the 15 interviews, six stakeholders interviewed were affiliated with organizations responsible for the planning and management of the protected areas and range from directors to tourism marketing within FUNDAECO, CONAP, and INGUAT. Two interviewees held minor positions in smaller organizations. In terms of tourists, out of more than 20 tourists approached, only nine agreed to participate, and included both national and international tourists. Challenges and limitations encountered while trying to conduct on-site interviews are discussed in Section 3.9.

\subsubsection{Coding of Responses}

After the interview responses were transcribed from the key stakeholders, a code manual was developed by carefully reading over the interviews and examining their first response, frequency of words and phrases, and the stances the interviewees have taken with respect to sustainable development and environmental protection. Tourists' responses were much simpler than key stakeholders to organize into categories. Discovering patterns, themes, and categories, and developing a codebook for analysis through interaction with the data involved a process of inductive analysis, and so did not require an existing structure to analyze and categorize the data 
(Patton, 2002). Therefore, open coding was utilized to break down, examine, compare, and categorize the data (Bryman et al., 2009). This allowed the exploration of commonalities or differences across interviews within the context of environmental issues and pressures, governmental support or lack thereof, sustainable development efforts, and management practices, which fed into determining the perspectives of stakeholders for the protected areas. The responses were also used to inform the decision of which layers to utilize in the GIS overlay analysis.

\subsection{GIS Data and Overlay Analysis}

Data pertaining to the boundaries of the protected areas were collected by systematically searching image and map data archives, such as the United States Geological Survey Earth Explorer. The GIS software utilized in this study was ArcGIS 10.1. An overlay analysis was selected because of its utility within the tourism industry for examining vulnerable areas (McGehee, et al., 2013). The data set obtained and utilized for this aspect of the study was compiled by the National Renewable Energy Laboratory (NREL), a laboratory of the U.S. Department of Energy's Office of Energy Efficiency and Renewable Energy. The purpose of the NREL was to conduct studies to determine solar energy potential in Guatemala. The data set included shapefiles for protected areas, roads, cities and communities with population values for each point, land use categories, elevation, water bodies, and administrative boundaries for all of Guatemala. The data were last updated in 2011 (NREL, 2011).

In order to carry out the overlay analysis, the layers used first needed to be identified. The coded results and subsequent analysis of the interviews informed the selection of layers for the GIS 
overlay analysis. For instance, if land use issues were a main source of problems for the development of sustainable tourism, then such a layer was included in the overlay analysis procedure. The layers were combined into one layer using the overlay analysis tools present in ArcGIS in order to identify zones of overall vulnerability within the context of tourism development. Figure 8 gives an overview of the procedure, which begins with the identification of thematic layers of data, and using their coinciding geographic positions to output a single composite layer. The number of layers depended on data collected from interviews, on-site observations, and secondary sources, particularly park plans as well as GIS data availability. A criterion for what constitutes environmental vulnerability was also developed alongside the overlay analysis.

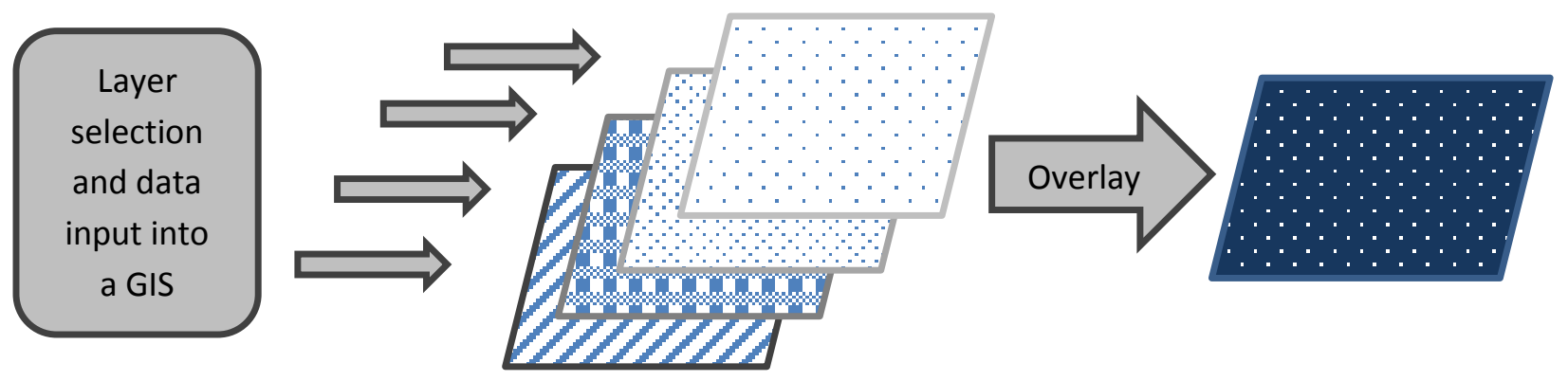

Figure 8 GIS overlay analysis showing the layers superimposed on one another and an overlay function performed to produce a composite map of vulnerability.

\subsection{Scope and Limitations}

In this section, the scope and limitations of the study are presented as factors that have placed constraints on the research, including the time of research, date range, places selected to conduct the study, and the availability of GIS data. The principal researcher's ethnic background is 
Guatemalan and this has allowed the researcher to develop an understanding of broader sociocultural contexts pertaining to issues of poverty and environmental degradation in Guatemala, which contributed to the development of the research question. Nonetheless, bias is present in that there is some level of familiarity with the environment and culture of Guatemala and thus has an impact on how the case in Izabal was interpreted. Yet, because the researcher does not have a close connection to Izabal, the bias is lessened and this, along with previous understandings, has aided in guiding the research from the initial question.

The aforementioned issue involving Guatemalan heritage, however, contributed to limitations during the process of obtaining potential tourists to interview. This is due to concerns of tourist assault and robbery by locals, which has been a significant issue in the past (Wallace \& Diamente, 2005). Tourists are usually warned, either by travel agencies or travel guides, to be cautious of speaking to locals by minimizing conversation or avoiding it all together. Thus, the response rate was low, resulting in nine tourist interviews. In one instance, a tour guide for a group of tourists declined a request for permission to interview said group due to concerns of diminishing the tourist experience.

Living arrangements placed constraints on the accessibility of sites. The location of residence necessitated at least one hour of travel time to access the nearest protected area, that being Rio Dulce National Park at the town of Las Fronteras. Selecting the three protected areas in close proximity to each other aided in facilitating travel between sites, taking the transfer from the boat tour of Rio Dulce National Park to San Filipe Castle as an example (see Table 5). Selecting other protected areas, such as Bocas Del Polochic, would not have been feasible because their distance 
would have required longer travel times, further reducing the defined time for the completion of fieldwork. This has implications in that reducing the number of sites also reduces the number of tourist encounters. Reducing the scope from the entire Lake Izabal area to the study area, however, allowed a more specific focus to be placed on the Lake Izabal-Rio Dulce nexus.

Fieldwork in Izabal was conducted from July 11 to July 17, 2013 while the remaining five days were spent in Guatemala City for a total of 12 days, including departure on August 2, 2013. Making site visits, observations, and conducting interviews were intended to be completed within this defined time frame. Given a longer time frame, more tourist interviews could have been conducted. The month during which fieldwork was conducted in also impacted tourist presence. December and January are considered to be the high-season for travel to Guatemala while the months of May and September exhibit low tourist numbers (see Figure 9) (INGUAT, 2013).

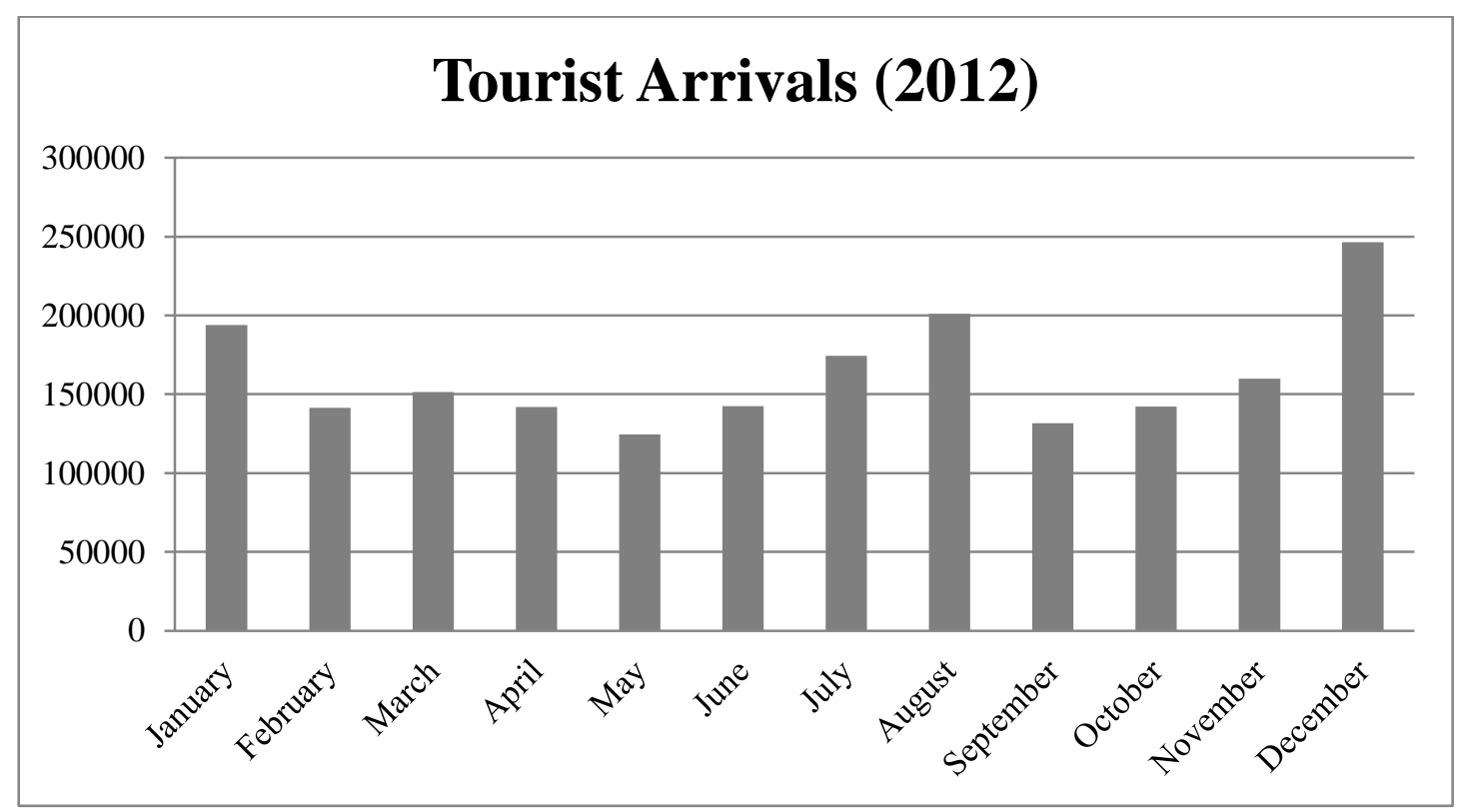

Figure 9 Tourist arrivals to Guatemala for the year 2012. Adapted from INGUAT (2013) 
The wet season, which occurs between May and September, plays a role in deterring tourists as it is marked by high levels of rainfall and an increase in humidity (Medina et al., 2008; YáñezArancibia et al., 1999). The month of August coincides with the start of mid-year holidays and festivals in Honduras and El Salvador, subsequenlty impacting arrivals (INGUAT, 2013). It should be noted that the statistics obtained from INGUAT are not separated by department, and hence may be misleading as other popular destinations of Guatemala (e.g. Antigua) may account for these high values.

The statistics available from the ports that receive cruises gives an indication of the number of tourists who are directed to specific sites throughout Guatemala. Two cruise ports are located in Guatemala: one in southern Guatemala, known as Port Quetzal, and the other in Izabal, which is known as Santo Tomas de Castilla (Crispín et al., 2012) and was briefly visited during fieldwork. The figures indicate that Antigua received 38,962 tourists while Rio Dulce received 4,035 tourists in 2012 (INGUAT, 2013). Figure 10 shows destinations and sites visited by tourists after arriving and disembarking at the cruise ports. Values are aggregated and do not represent only one port, but both (i.e. Port Quetzal and Santo Tomas de Castilla). 


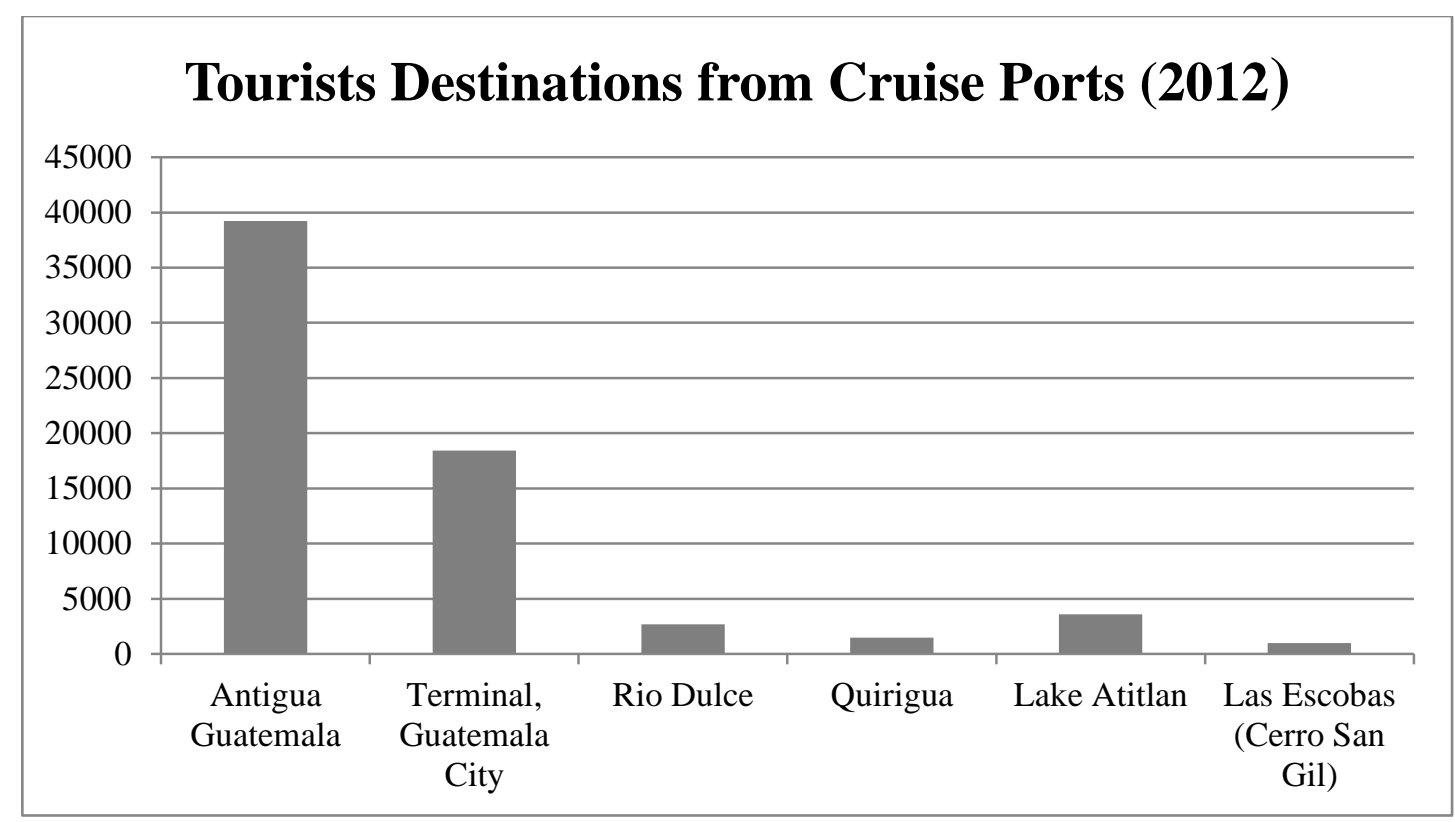

Figure 10 Tourist destinations from cruise ports for 2012. Adapted from INGUAT (2013)

Difficulty was encountered for certain sites that had undefined or multiple entrance and exit access points. Cerro San Gil is a large protected area but within that area there are numerous sites where tourists may be found. Multiple entrance points pose issues in monitoring the number of entrants (WTO, 2004) and, in this study, enhanced the challenge of obtaining a greater number of tourist interviews. Secondly, entrance into the protected area may have no formal access point. This is the case with Rio Dulce National Park and Chocon Machacas because there is no discernible point where tourists come and go, except for the town of Las Fronteras. Thus, conducting qualitative research in natural settings poses challenges because locating tourists is time consuming (Reinius, 2011).

Difficulty in obtaining interviews from planners and managers of the protected areas under study occurred particularly with government organizations, such as INGUAT. Emails were not replied to and phone calls misdirected or simply not answered. This may have been due to limited time 
to respond or a lack of interest in partaking in research. Although providing compensation or monetary incentives have been known to increase response rates (Bryman et al., 2009), no such incentives were utilized in this study for either tourists or key stakeholders for the planning and management of the protected areas.

As case study design is not intended to be broadly generalizable but instead to provide a thick description of a phenomenon under study sufficient for users to determine its applicability to their situations, the number of interviews combined with other data sources is in keeping with the method. The basis of generalization is established in this case when readers recognize essential similarities to cases of interest to them (Stake, 1978). That is, the result is user generalizability, which allows the reader to determine the extent to which the case study's findings can be applied to their context (Merriam, 2002).

The triangulation of data sources strengthens the validity of the study (Patton, 2002). For example, comparing observations with interviews, comparing perspectives of people from different points of view (e.g., managers and tourists), and cross-checking interviews against documents, such as master park plans, can aid in validating responses from the interviews (Patton, 2002). Convergence of multiple sources increases confidence in the findings and a divergence opens doors to different understandings of a phenomenon (Patton, 2002). From a quantitative standpoint, the documents provided numerical information to justify tourist arrivals and growth in protected areas. 


\subsection{GIS Limitations}

Geospatial data models represent a simplified version of reality and, because of the complexity in modeling that reality, all geospatial data in some shape or form contains a certain degree of error (Devillers \& Jeansoulin, 2006). The accuracy, how close data values are to the true values, and precision, the exactness of a value, influence uncertainty of a dataset and thereby may result in discrepancies (Roth, 2009). For instance, a city represented on a GIS map may have slightly different coordinates, or may not be precisely positioned due to having coordinate values rounded off. The type of map projection system utilized can contribute to the uncertainty of a feature's position (Devillers \& Jeansoulin, 2006). Utilizing different map projections may create distortions in the coordinates of a point or feature and this is because various projection systems exist to project three-dimensional objects onto two-dimensional surfaces (Devillers \& Jeansoulin, 2006).

In order to minimize the aforementioned discrepancies, a dataset from a single source was utilized. In this case, the dataset was obtained from the NREL, which contained files, among others, for protected areas, roads, water bodies, and cities. The projection of the data was examined in ArcGIS by accessing the data frame properties. Utilizing a dataset from a single source aided in ensuring that one projection system was used for the dataset and this standardization minimized distortions in positional accuracy and precision. Any other data not obtained from this source were examined for their projection system. Other data integrated into the GIS that did not involve coordinates were accomplished through the joining of tables and were obtained from the most recent sources possible, particularly from secondary sources such as park plans. 
Temporal quality was also kept in mind as it relates to the validity of changes in each dataset in response to real-world changes, including the rate of updates, which has an impact on the quality of a dataset (Haklay, 2010). This has implications for the accuracy and precision of features in the data, and therefore, updates were examined. According to the NREL, the dataset was last updated in 2011 and so represented a recent update and provided some level of confidence in the data. It was uncertain, however, if the updates were reflected in all the data within that dataset or for selected components. The accuracy and precision of data in the context of temporal changes were also verified through on-site observations of real-world objects, such as the placement of roads and towns in relation to the protected areas and Lake Izabal. 


\section{Chapter 4}

\section{Results and Findings}

\subsection{Introduction}

This chapter outlines the main findings and results of the analysis of the data collected through fieldwork and other methods, as described in Chapter 3. The chapter delineates the roles of parks and protected areas in Izabal at the Lake Izabal-Rio Dulce nexus from the viewpoints of key actors in tourism and conservation organizations, as well as those of tourists. The economic and environmental implications are then explored from the perspectives of each entity. The GIS analysis and results are examined in terms of determining vulnerable areas that may require further attention in order to progress with a sustainable development framework. Findings are corroborated using park plans and government-mandated developmental plans for Izabal. A section dedicated to discussion of the findings within the context of sustainable tourism development in the protected areas of Izabal and the use of GIS to determine vulnerable zones are provided in Chapter 5.

\subsection{Overall Perspectives on Protected Areas and Tourism in Izabal}

General themes related to the view of tourism in Izabal are discussed as they serve to contextualize the actions taken by tourists, planning and management organizations, and communities within a tourism developmental context. These perspectives were obtained from the analysis of interviews with representatives from FUNDAECO, INGUAT, CONAP and an unnamed community organization. The key informants work in planning/management capacities in organizations that have a stake in the development of tourism within the protected areas. The 
informants are labeled as R1 through R6. Their views in planning and managing processes are explored with connections made among tourism and the communities within the protected areas.

The general view of protected areas in Izabal, and in Guatemala, from key informants is positive due to the many perceived benefits these areas can provide. Conservation and the protection of the natural resources were referenced by the key informants as benefits and as primary reasons for their positive outlook. Protected areas as a driver of tourism to Guatemala were also perceived to be a positive attribute of these areas. Table 6 shows the perspectives of key informants regarding the importance of protected areas in Izabal, and in general, to tourism.

Table 6 Perspectives of protected areas in Guatemala

\begin{tabular}{ll}
\hline Respondent & Perspective \\
\hline $\mathbf{R 1}$ & $\begin{array}{l}\text { "The parks of Guatemala are one of the options that exist currently for the } \\
\text { conservation of natural resources, and of the landscapes but are also... an } \\
\text { alternative way of generating income." }\end{array}$ \\
"They [protected areas] are the prime matter of tourism in the area of Izabal." \\
$\mathbf{R 3}$ & "To help the communities to develop and to help us in protecting the resources" \\
$\mathbf{R 4}$ & $\begin{array}{l}\text { "The attraction for the tourists is...the ecosystem that we have here in } \\
\text { Guatemala" } \\
\text { "Most of the protected areas of the country are the principal tourist destinations } \\
\text { that the visitors come to see in Guatemala." } \\
\text { "Of the tourist destinations most important in Guatemala, almost all are within, } \\
\text { or are, protected areas." }\end{array}$ \\
\hline
\end{tabular}

The responses note benefits of conservation, income generation, and community development but the protected areas are also recognized as an important, if not the main, tourist destination for Guatemala. The natural landscape is of primary importance to the protected areas in Izabal, and Guatemala in general, because they safeguard significant natural resources (R5). In Cerro San 
Gil, tourism is seen as an alternative way of generating income to meet the needs of communities as well as a "positive alternative that can lower the pressure of the nucleus zone" (R3). These statements reinforce the concept that the natural landscape is of primary importance because of its function in serving as a means to generate tourism and perceived benefits of conservation and income generation.

In terms of the significance of tourism, several key informants agreed that tourism is of considerable importance, using words such as "very," "quite a bit," and "most" to describe its importance. The reasons for its importance, however, varied. Many discussed tourism in economic terms, as a way to generate income and employment opportunities (R2; R3; R5; R6). In one case, tourism was seen as "a good thing that can help the protected area" (R3) via the lowering of pressure to the nucleus zone and developing tourism by establishing services in the protected area. The area's close proximity to the cruise ports was also described as an advantage, pointing to the potential to increase visitation (R1; R5). This view perhaps stems from the low visitation to Rio Dulce and Las Escobas in Cerro San Gil, as indicated in Figure 10.

One respondent classified tourism in third place economically, after fishing and agriculture, but from a conservation standpoint, the respondent ranked tourism as number one (R2). It should be noted that the questions did not ask tourists or key informants to rank tourism's importance. According to SEGEPLAN, a planning department of the Government of Guatemala, tourism is the third most important economic sector in Izabal due to the tourism services, such as hotels and tourist transportation, that serve to generate revenue for the department (SEGEPLAN, 2011). Another facet of tourism that was raised was the importance of tourism as a vehicle for education 
such that people can "come to know many things that will be useful in order to maintain an ecological equilibrium between human beings and the environment" (R4).

The views expressed of the role protected areas play in Izabal mainly relate to the protection of natural resources and nature as the main attraction for tourists. Tourism, in general, is viewed as important by the interviewees for varying reasons regarding community development, income generation, and environmental conservation. These aspects are described in greater detail in further sections of this chapter alongside the perspectives of key stakeholders and tourists, emphasizing on the connectivity and complexity of tourism to the protected areas. Differences in viewpoints may be related to the stakeholder's positions within an organization, which may be associated with planning or management of the protected areas. Organizations may be governmental or non-governmental and this impacts their level of interaction with the protected areas and this is discussed in section 4.4.

\subsection{Tourist Perspectives}

Understanding the viewpoints of tourists is important in establishing how they, in general, interact with their surroundings and how that influences tourism development. In querying their main purpose of travel to the region of Izabal, most interviewees stated that their purpose of travel was to visit or explore a new area, an area perhaps not seen before. Only a few mentioned the beach, referring to Lake Izabal as the main attraction that brought them to Izabal. Certainly, several locals and a few tourists were observed swimming during a visit to the lake (see Figure 11) (Fieldnotes, July 14, 2013). Only one respondent explicitly stated that nature was the main purpose of travel to Izabal. The tourists did not specifically mention that their main attraction 
was a protected area which may suggest that these areas are not immediately recognized as destinations when arriving in Izabal. While a few respondents stayed for at least one night, most were daytrips to the protected areas.

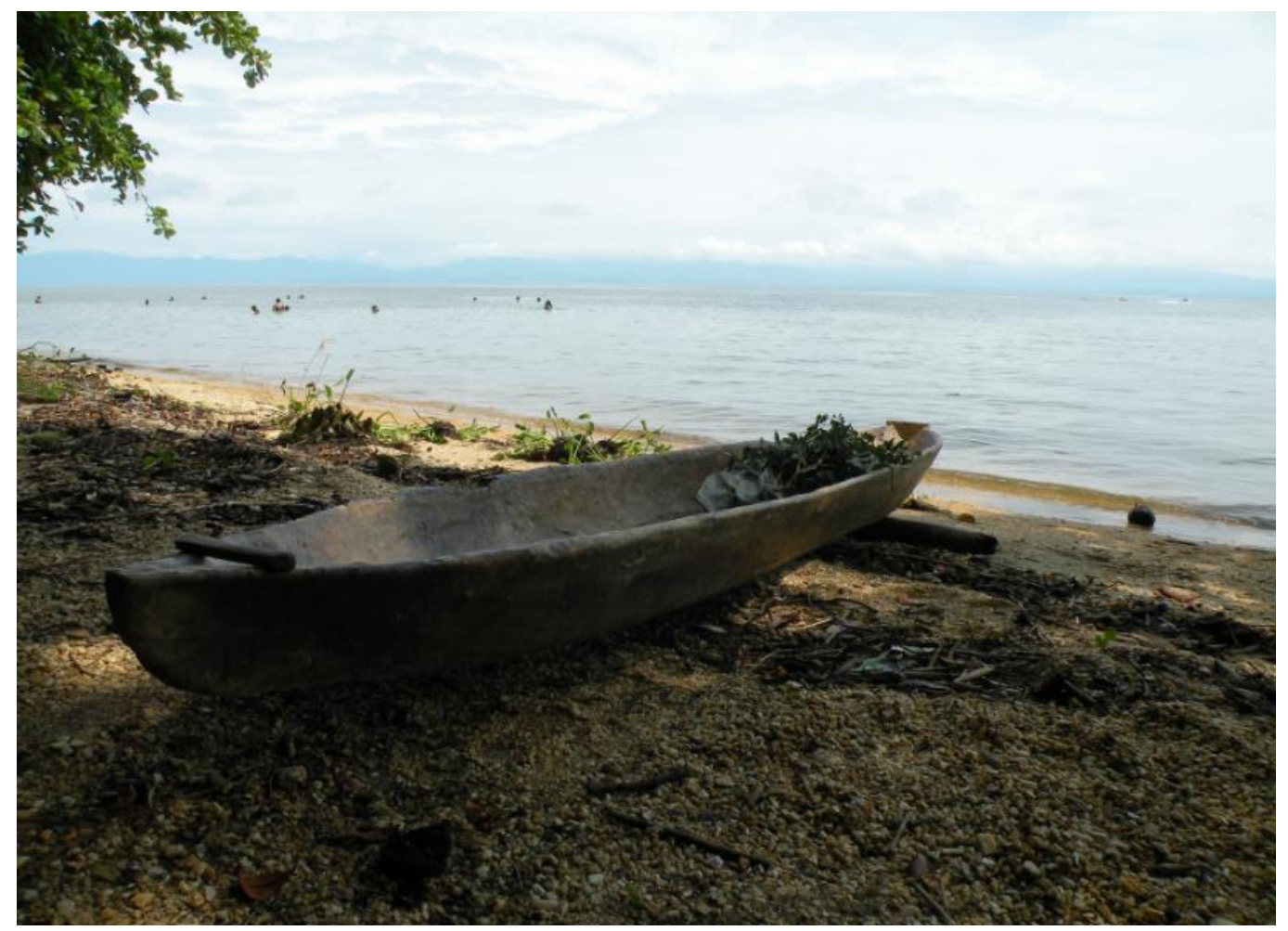

Figure 11 View of Lake Izabal. Photo credit: Cesar Gonzalez

Tourists are drawn to a destination by an attracting factor, which has implications for the organizations and the communities within the protected areas in the way tourism is marketed. Examining the responses tourists offered with respect to what attracted them to the protected areas within Izabal provides some insight into their perspectives of tourism. Amongst tourist responses, several expressed that the environment was the dominating factor in attracting them to the sites. This ranged from the tropical climate to the presence of wildlife. Since multiple answers were permitted, some responses also included the cultural aspects of Izabal and not the 
protected areas specifically. The responses, shown in Table 7, are characterized into two main categories of the environment and culture. Tourists were asked to elaborate on their responses, which resulted in subcategories of specific reasons as to what attracted the tourists to the protected areas in Izabal.

Table 7 Factors that attracted tourists to the protected areas in Izabal

\begin{tabular}{|c|c|c|}
\hline Main Categories & Subcategories & Examples Given \\
\hline \multirow[t]{4}{*}{ Environment } & Climate & Tropical weather \\
\hline & Wildlife & Manatees, birds \\
\hline & Nature & "Untouched" nature \\
\hline & Landscape & $\begin{array}{l}\text { Mountain sceneries, forests, } \\
\text { lake views }\end{array}$ \\
\hline \multirow[t]{4}{*}{ Culture } & Sites & Ranch (for cheese production) \\
\hline & Ambience & Lively, lots of tourists \\
\hline & Crafts & $\begin{array}{l}\text { Artisan crafts (hollowed out } \\
\text { turtle shells) }\end{array}$ \\
\hline & Food & Seafood, markets \\
\hline
\end{tabular}

The responses from Table 7 show a certain degree of affinity for climate, as it was mentioned most often (4 mentions), followed by the environmental landscape ( 3 mentions), and wildlife and nature ( 2 mentions each). The reasons listed for the cultural aspects relate to cultural sites, the ambience, crafts (each having been mentioned once), and food ( 2 mentions). The perspectives of the tourists fall in line with that of the key informants, in which the natural setting of Izabal, its climate, landscape, and wildlife are main components that define tourism and attract tourists to protected areas in Izabal. From this, it appears that the natural environment drives visitation to the area. 


\subsubsection{Influences on Tourist Arrivals in Izabal}

Recent management decisions have had implications for tourist arrivals in Izabal and in the protected areas. The implementation of a 10 USD tax on tourists upon arrival at the cruise port in Izabal, on behalf of INGUAT, resulted in decreasing tourist numbers (R1). As stated by one respondent, boats and cruises would bring, on average, 1200 people but only 600 to 700 would choose to visit the protected areas (R1). The tax was implemented to generate greater revenue from tourists but was received negatively by cruise companies, threatening to bypass Guatemalan ports which would harm commercial activity in the department of Izabal (Pérez, 2009). More recently, the topic was brought up in the media, whereby a government official cited the tax as directly influencing the cancellation of 61 cruises from a pool of 91 (Herrera \& Dardón, 2014). According to the key informant, although the situation is currently improving, the action taken by the government is a demonstration of how management decisions affect visitation potential (R1).

There is also an apparent lack of support from large travel agencies and tour operators for community tourism in lesser known areas as tour operators see it as "very difficult, more complicated to work in" and thus prefer to send to people to popular sites such as Tikal and Antigua (R2). Additionally, not all protected areas are developed to sustain tourist activities and are therefore not visited by tourists (R5). In one case, a tourist interviewee stated that collaboration between governments and international organizations has the potential to enhance tourism in the protected areas. Hence, because the majority of tourism within the protected areas in Izabal is community-managed, or attractions are on community property, the lack of support has implications for income generation and tourism development in communities (R2). 
Tourist safety was another concern addressed by a key informant (R1) and one that was attributed to impacting visitation to the area. Upon disembarking from the cruise, tourists are allowed to "look for a tour they like and for the price they decide," which includes tours with uncertified tour operators (R1). The lack of security measures in place by the uncertified tour operators resulted in the assault and death of a tourist, which negatively impacted tourist arrivals for the area under study (R1). Although the situation has been improving, uncertified tour operators continue to work in areas like Rio Dulce National Park, where operators offer discounted boat rides of Lake Izabal and Rio Dulce to tourists (Fieldnotes, July 15, 2013). Security concerns, however, were not raised by tourists when queried on what they thought planners and managers could do to enhance the area as a tourist attraction. Rather, concerns were directed towards environmental maintenance and better tourism planning. Table 8 presents proposed improvements to be made in managing and planning tourism.

Table 8 Potential improvements to tourism as suggested by tourists

\section{Primary improvements Secondary improvements}

Cleanliness, maintenance and enforcement (includes littering)

Signage of scenic viewpoints and tourist information in brochures

Ask for support, greater collaboration
Trained guides to speak on natural environment

Environmental Education

\section{Amenities, such as washrooms}

As presented in Table 8, the cleanliness of the parks, maintenance, and enforcing rules that prevent pollution or littering were the most mentioned improvements by tourists that can potentially enhance the protected area and the lake area as a tourist attraction. The dominating 
perspective appears to indicate that the protected areas are unclean and unkempt, as this was mentioned most. The lack of cleanliness is corroborated by the Izabal Development Plan (SEGEPLAN, 2011), whereby it is recognized that Izabal does not have efficient control systems to enforce laws and regulations related to environmental management, such as proper waste disposal. Establishing signs indicating scenic viewpoints and providing tourist information in the form of brochures were suggestions given by a few respondents. One scenic viewpoint of Lake Izabal did have a sign, but was not maintained as it was not clear and litter was present (see Figure 12) (Fieldnotes, July 13, 2013).

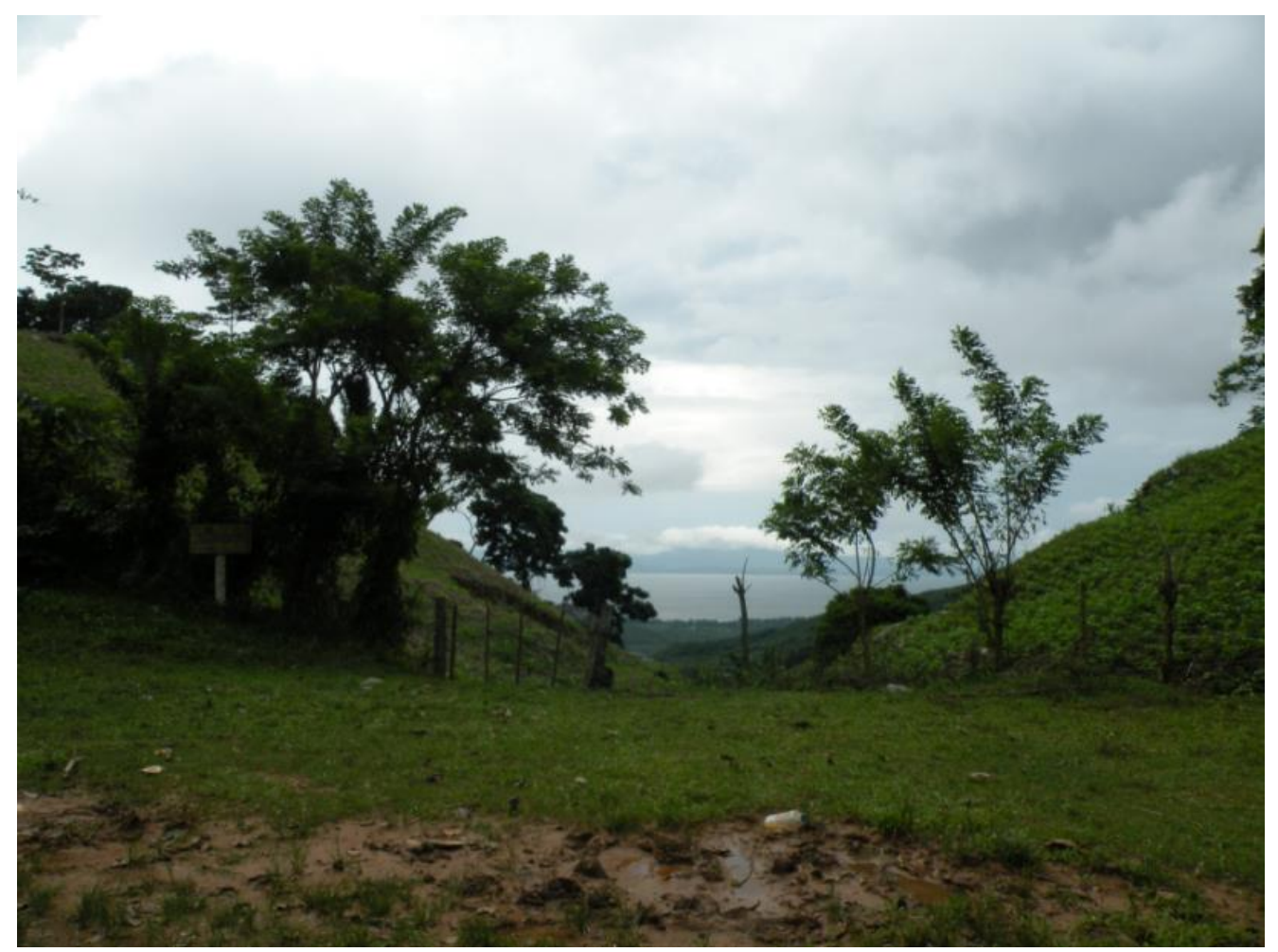

Figure 12 Scenic view of Lake Izabal, litter in the foreground and the sign obscured. Photo credit: Cesar Gonzalez 
Secondary improvements included the need for trained guides and environmental education. The responses again put emphasis on the importance of the environment to the Lake Izabal-Rio Dulce area and the need to maintain it. There are instances where signs are posted to inform tourists to maintain the area but their placement may be obscured or hidden, as shown in Figure 13 below. The sign, found in Rio Dulce National Park, was not placed on the trail heading towards San Filipe Castle, nor at the entrance, but in front of an outdoor gift shop (Fieldnotes, July 15, 2013).

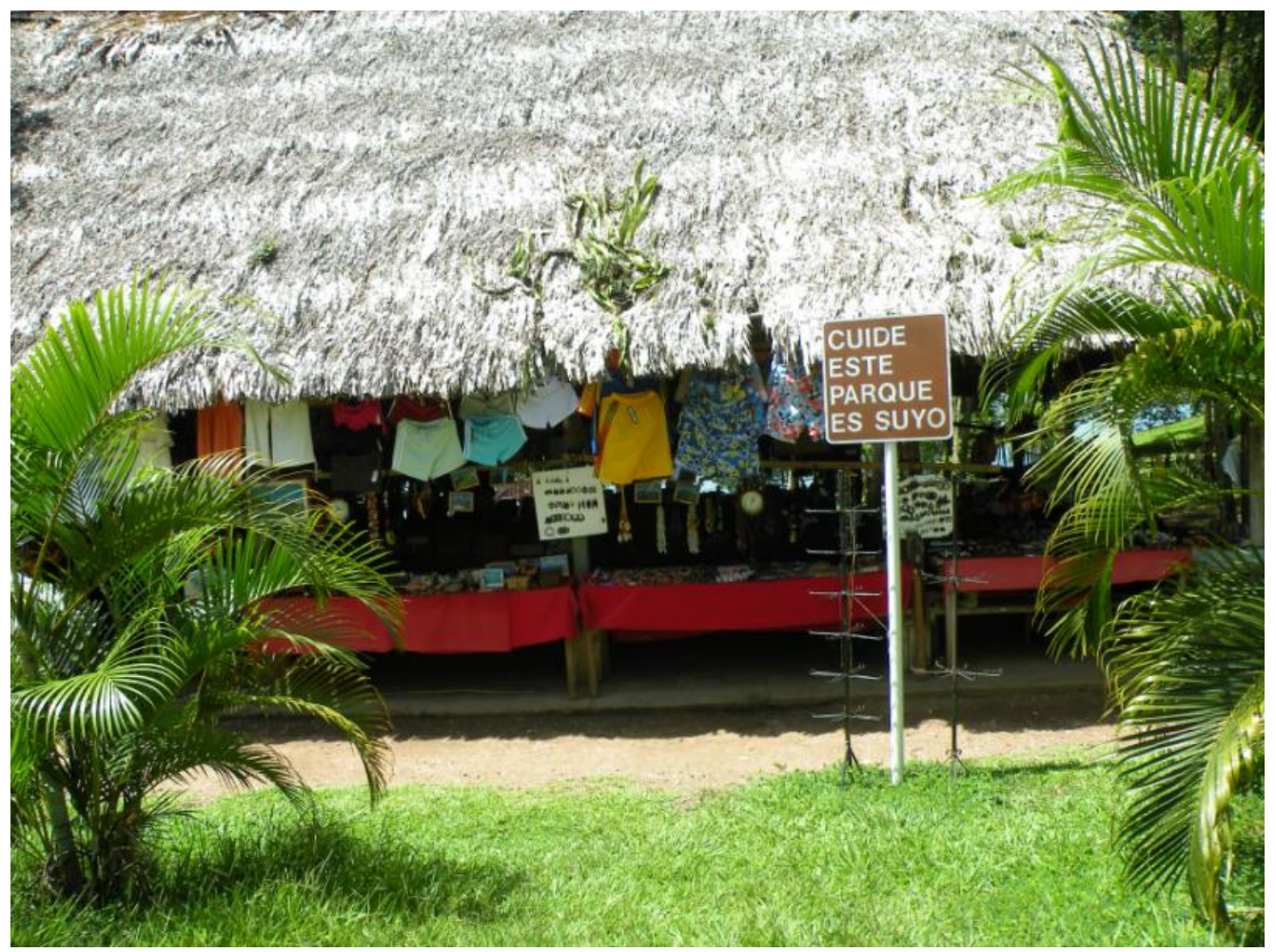

Figure 13 Signage in Spanish which translates to "Take care of this park, it's yours" in front of an outdoor gift shop. Photo credit: Cesar Gonzalez

The development of tourism in the protected areas is important, particularly for income generation, but the lack of support shown by planning and management entities has weakened tourist security and redirected tourists to other areas. This in turn reduces support for 
community-based tourism, impacting communities with fewer tourist numbers. Such a chain demonstrates that economic and organizational relationships are established throughout. Moreover, improved cleanliness, maintenance, and enforcement as well as the enhancement of available tourism information are possible objectives that planners and managers could work towards, particularly when environmental conservation and sustainable development are already on the agenda of the key informants.

\subsection{Perspectives of Planning and Management Stakeholders}

The perspectives of the key stakeholders who represent organizations that have a stake in the planning and management of protected areas around the Lake Izabal-Rio Dulce region are discussed in this section. Perspectives on obstacles to sustainable tourism development, environment, social, and economic impacts, and conservation work are presented. Insight into how the organizations collaborate with one another is also provided.

\subsubsection{Perceived Obstacles to Tourism Development}

The key informants recognize that obstacles exist with respect to the management of the protected areas that may either hinder sustainable tourism development or conservation objectives. Although their responses may vary due to the stakeholders' association with different organizations, responses are similar throughout. Table 9 lists the responses of the interviewees and are categorized as primary, secondary and tertiary based on what issue they responded with first, second, and third, respectively. The responses are also categorized into categories of finance, management, or planning. 
Table 9 Obstacles related to the management and planning of the protected areas in Izabal

\begin{tabular}{|c|c|c|c|}
\hline & Primary Obstacle & Secondary Obstacle & Tertiary Obstacle \\
\hline $\mathbf{R 1}$ & $\begin{array}{l}\text { Finance - government } \\
\text { support for budget }\end{array}$ & $\begin{array}{l}\text { Finance - current support is } \\
\text { for income for park rangers }\end{array}$ & N/A \\
\hline $\mathbf{R} 2$ & $\begin{array}{l}\text { Management - regulations } \\
\text { for service providers and } \\
\text { tour operators }\end{array}$ & $\begin{array}{l}\text { Management - revision to } \\
\text { management system of the } \\
\text { tourism industry }\end{array}$ & $\begin{array}{l}\text { Management }- \text { No } \\
\text { compulsory admission fee } \\
\text { for Rio Dulce National Park }\end{array}$ \\
\hline R3 & $\begin{array}{l}\text { Management - Compliance } \\
\text { with, and disorganized, laws }\end{array}$ & $\begin{array}{l}\text { Planning - No } \\
\text { sustainable development } \\
\text { policies }\end{array}$ & $\begin{array}{l}\text { Planning - No investment } \\
\text { in the generation of income }\end{array}$ \\
\hline R4 & $\begin{array}{l}\text { Planning - Lack of political } \\
\text { action to protect sites }\end{array}$ & N/A & N/A \\
\hline R5 & Finance - Lack of support & $\begin{array}{l}\text { Planning - Lack of } \\
\text { resources for protected areas }\end{array}$ & N/A \\
\hline R6 & $\begin{array}{l}\text { Planning - Not all areas } \\
\text { have a plan to develop } \\
\text { tourism }\end{array}$ & N/A & N/A \\
\hline
\end{tabular}

The main theme that arises out of the responses involves a lack of governmental support and a lack of political action. The responses are related as there appears to be an absence of a coherent management structure that ties in governmental support, financial support, and the strengthening and enforcement of regulations, such as laws, which ties into the lack of sustainable development policies. CONAP was explicitly mentioned in the responses as the one to criticize for the lack of action taken to develop tourism (R1; R2). Such views are reflected even within CONAP. A representative from CONAP stated that the "management of tourism of the system of protected areas is...barely beginning" (R6). An informant (R5) at INGUAT also recognized that the system of protected areas is underfunded and yet are "the principal tourist destinations that the visitors [visit] in Guatemala." 
Tourism development appears to be progressing positively for Cerro San Gil. Within the protected area, two parks were created, Las Escobas and Green Cove, both managed by FUNDAECO in order to protect the water springs within the area and to prevent natural resource extraction, land use change, and human encroachment (R1). Information signs (see Figure 14) are also established throughout the sites, and the trails in Las Escobas have been improved through the collection of entrance fees, which are structured for different groups (Fieldnotes, July 12, 2013). The protected areas of Rio Dulce and Chocon Machacas, however, appear to not have followed suit in their development as there are no entrance points established (R5), no fee collection (R2), and no time restrictions for public access to the areas (SIGAP, 2013).

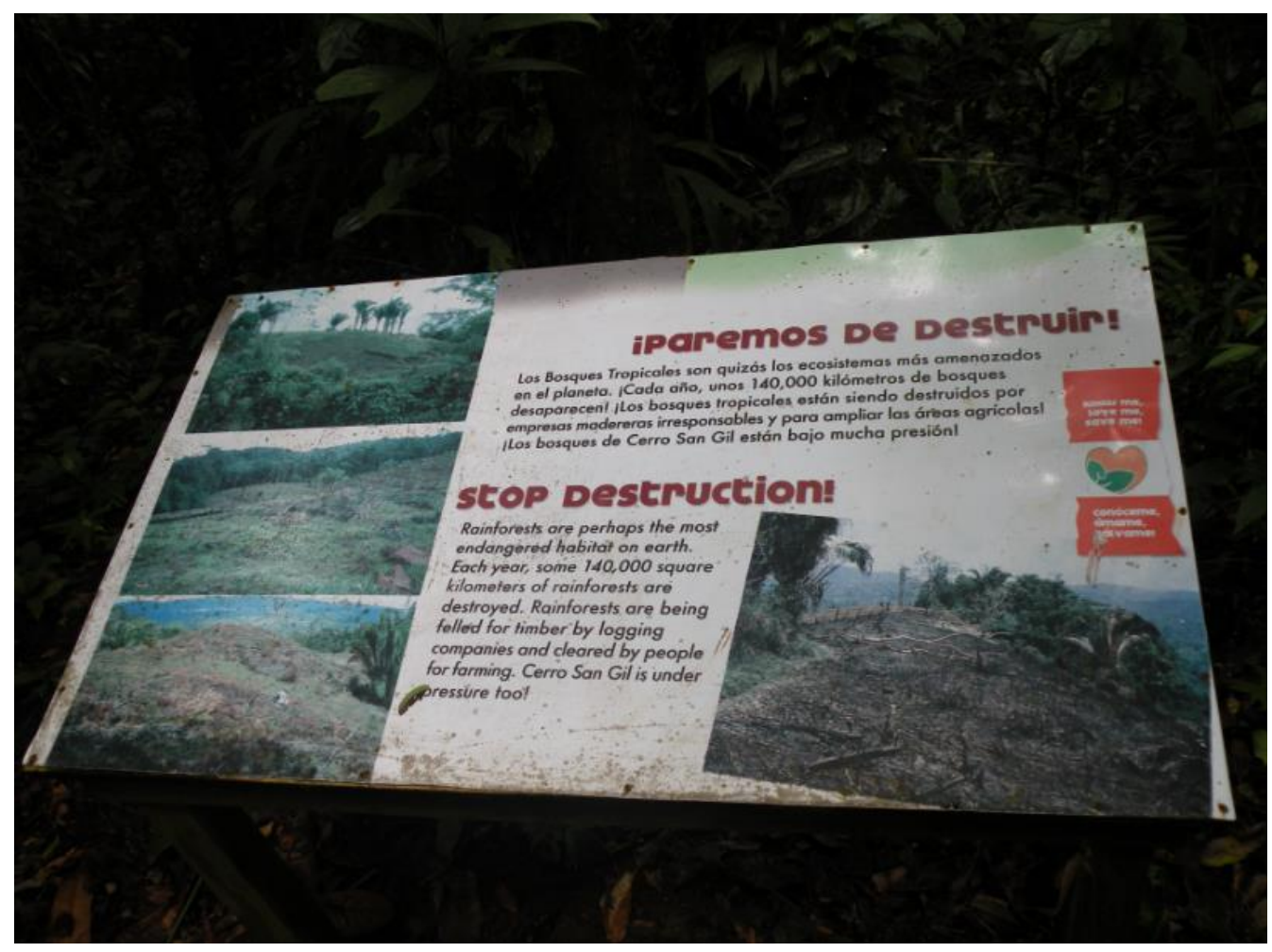

Figure 14 An information sign in both Spanish and English along a trail in Cerro San Gil informing tourists and visitors about the impact of deforestation. Photo credit: Cesar Gonzalez 
There appears to be a lack of partnerships between public and private entities, as is the case in Rio Dulce, where private tour operators do not pass on any revenue to the national park or to other sectors of the tourism industry (R2). The lack of vision for organizing groups of private tour operators and service providers is viewed as a limiting factor for economic development in Izabal (SEGEPLAN, 2011). No clear benchmark to address this issue is given in the Development Plan of Izabal (SEGEPLAN, 2011). Hence, foreign investment is "not seen" and therefore not directed into the development of sustainable tourism because revenue is not distributed to other sectors (R3).

\subsubsection{Perspectives on Social, Economic, and Environmental Impacts}

Social impacts raised by key respondents involve land tenancy issues and project development. In 2005, the Registry of Cadastral Information (RIC) started recording land registry information in order to solve conflicts over land ownership (SEGEPLAN, 2011). However, as indicated by the respondents, these problems continue today. Legal rights to lands within the protected areas remain unclear and opposition by the communities has resulted in challenges with moving forward with "productive projects" (R1). The master plan for Cerro San Gil refers to productive projects as alternative uses of natural resources in order to provide benefits to the communities, either through conservation efforts or through tourism (CONAP et al., 2006). Moreover, projects involving tourism infrastructure are not created "from a local foundation," and are deemed as unsustainable development because the projects do not take into consideration the needs of the local communities (R3). 
Drug-trafficking was raised as an economic and social issue because of its impact on community development as the money has "a lot of power behind it" and ends up in the hands of community actors (R2). The income generated from drug-trafficking is utilized to purchase land and expand cattle farms, thereby inducing land-use change (R2). According to the Rio Dulce National Park Master Plan, the lack of security measures has enabled this activity and in turn has negatively impacted the area as an attractive tourist destination (CONAP \& FONACON, 2004). Furthermore, cattle farms have long been recognized as a threat to the natural resources of the three protected areas (CONAP \& FONACON, 2004; CONAP et al., 2006; Ixcot Yon, 2005).

In terms of economic impacts, two interviewees agree that a lack of employment and the resulting poverty not only strains social fabrics in these communities, but creates an economic dependency on the natural resources, which further exerts pressure on the environment. In recent years, the income generated by tourism has experienced a decline, further impacting the level of poverty in Izabal (SEGEPLAN, 2011). Deforestation resulting from unsustainable forestry practices was raised as an issue and one that is the outcome of the dependence on natural resources for economic survival (R4) (Figure 15). Environmental degradation, a result of the aforementioned pressure, could deter tourists from visiting the protected areas as the natural setting of Izabal is a main driver for tourists. 


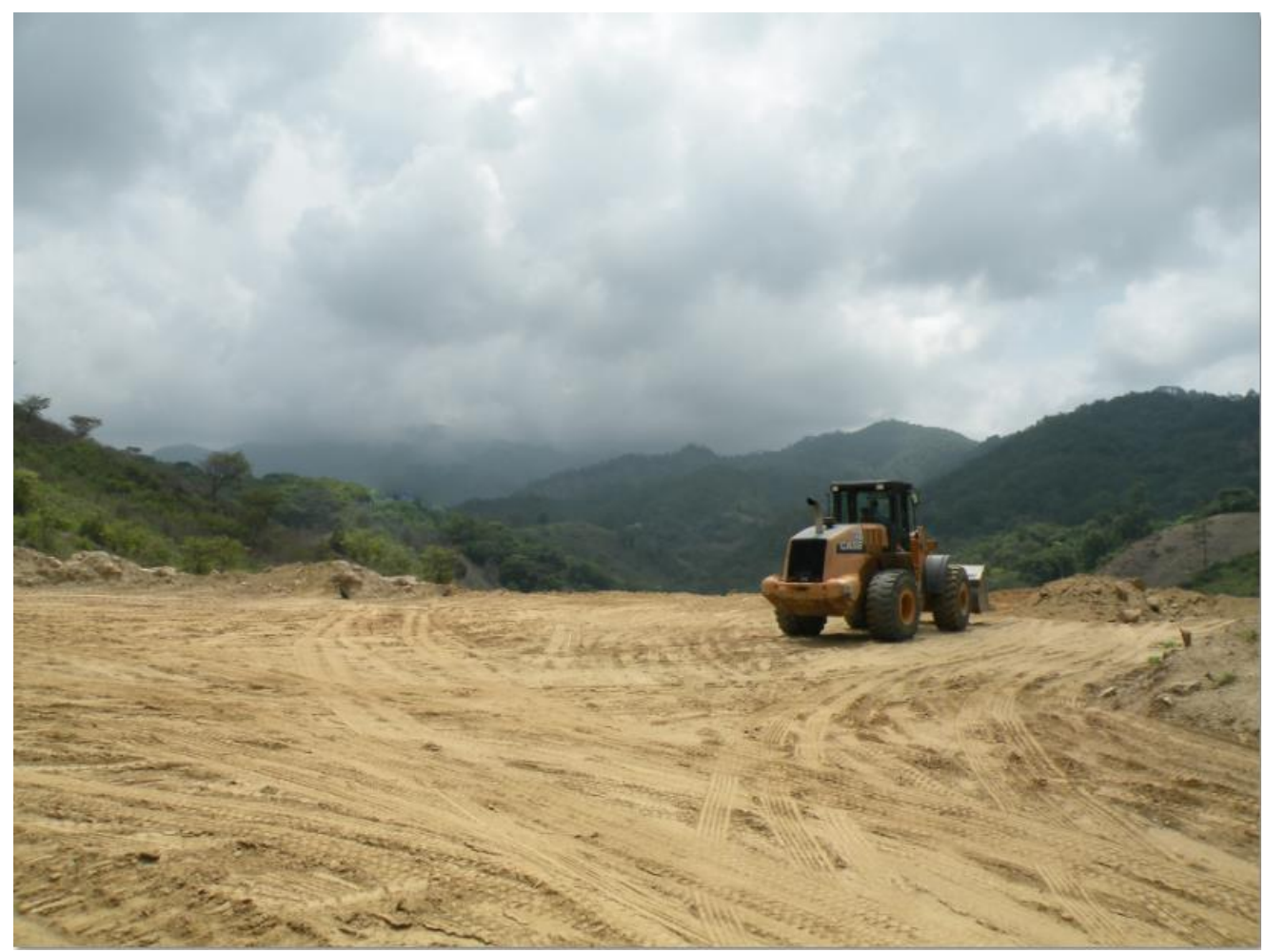

Figure 15 Deforestation in Izabal. Photo credit: Cesar Gonzalez

In attempting to achieve sustainability, the social, economic, and environmental impacts within the protected areas, as described above, are addressed to varying degrees. Employment opportunities are generated in Cerro San Gil by training young people as local guides but also in employing skilled workers, including engineers, as food vendors (R1). One interviewee stated that FUNDAECO works to provide "technical support to the communities," but also to the government by enforcing fishing bans in the area of Rio Dulce (R2). Education is another strategy applied to address environmental impacts (R4). In an informal conversation, it was revealed that children are educated in a bottom-up strategy that seeks to change the environmentally destructive behaviour of their elders (Fieldnotes, July 12, 2013). Governmental organizations like INGUAT coordinate with CONAP to develop tourism and promote developed 
tourism products (R5). CONAP on the other hand provides administrative support to smallerscale organizations for tourism planning and managing visitors (R6).

\subsubsection{Conservation Work}

Conservation work is conducted as a means to gauge the health of the forest, to protect sensitive ecosystems or species, and maintain economic profitable features. Table 10 shows a list of the main lines of conservation work as provided by the key informants. The community member stakeholder is not included in this table because he and the community at large do not conduct major conservation work. Also not included are informants from INGUAT and CONAP as they are not directly involved in carrying out conservation work for the protected areas in this study (R5; R6). They are, however, aware of certain species conservation efforts in Izabal, such as the manatee, aquatic birds, and the jaguar (R5; R6).

Table 10 Main lines of conservation work conducted in the protected areas

\begin{tabular}{llll}
\hline Conservation work & R1 & R2 & R3 \\
\hline Secondary efforts & $\begin{array}{l}\text { Spring water - chiefly } \\
\text { for Cerro San Gil due } \\
\text { to extensive water } \\
\text { network }\end{array}$ & Amphibians & Bird monitoring \\
Tertiary efforts & $\begin{array}{l}\text { Landscape and } \\
\text { ecosystems - } \\
\text { mangroves, rocky } \\
\text { areas and wetlands }\end{array}$ & Fish & Amphibians and three \\
& & & endemic species. \\
\hline
\end{tabular}

From the responses, the most important line of conservation work involves birds and the monitoring of their habitat and species. For the protected areas under study, bird conservation 
was the first major project undertaken, initiated some 20 years ago (R2). Amphibians, another major line of conservation work, and birds act as indicators of the health of the forest in terms of food availability and climate suitability (R1). One interviewee mentioned the conservation of the jaguar as it is recognized as an iconic species requiring protection in the areas in this study (CONAP \& FONACON, 2004; CONAP et al., 2006; Ixcot Yon, 2005). The motivation to support fish conservation stems from their economic importance to the region of Izabal, serving as a source of income. In terms of the water source, it has been protected because it serves as drinking water for the communities and towns in the region (Fieldnotes, July 12, 2013).

\subsubsection{Overarching Management and Planning Processes}

The topic of decision-making provided insight into the length of time required to declare and establish a protected area. In order to declare a site to be protected, technical studies must be conducted to support its declaration (R6). A biodiversity, economic potential, and land-use study must be conducted (R2). This process usually takes 6 to 7 years and is officially made by the Congress of Guatemala (R1). Once that occurs, the protected areas are managed by either CONAP or a non-governmental organization, such as FUNDAECO in Cerro San Gil (R1). Although the protected areas studied, Cerro San Gil, Rio Dulce, and Chocon Machacas, have different management and planning systems specific to them, an overall schematic of the general processes are presented in Figure 16, as gathered from the interview responses and supplemented with park plan documents. 


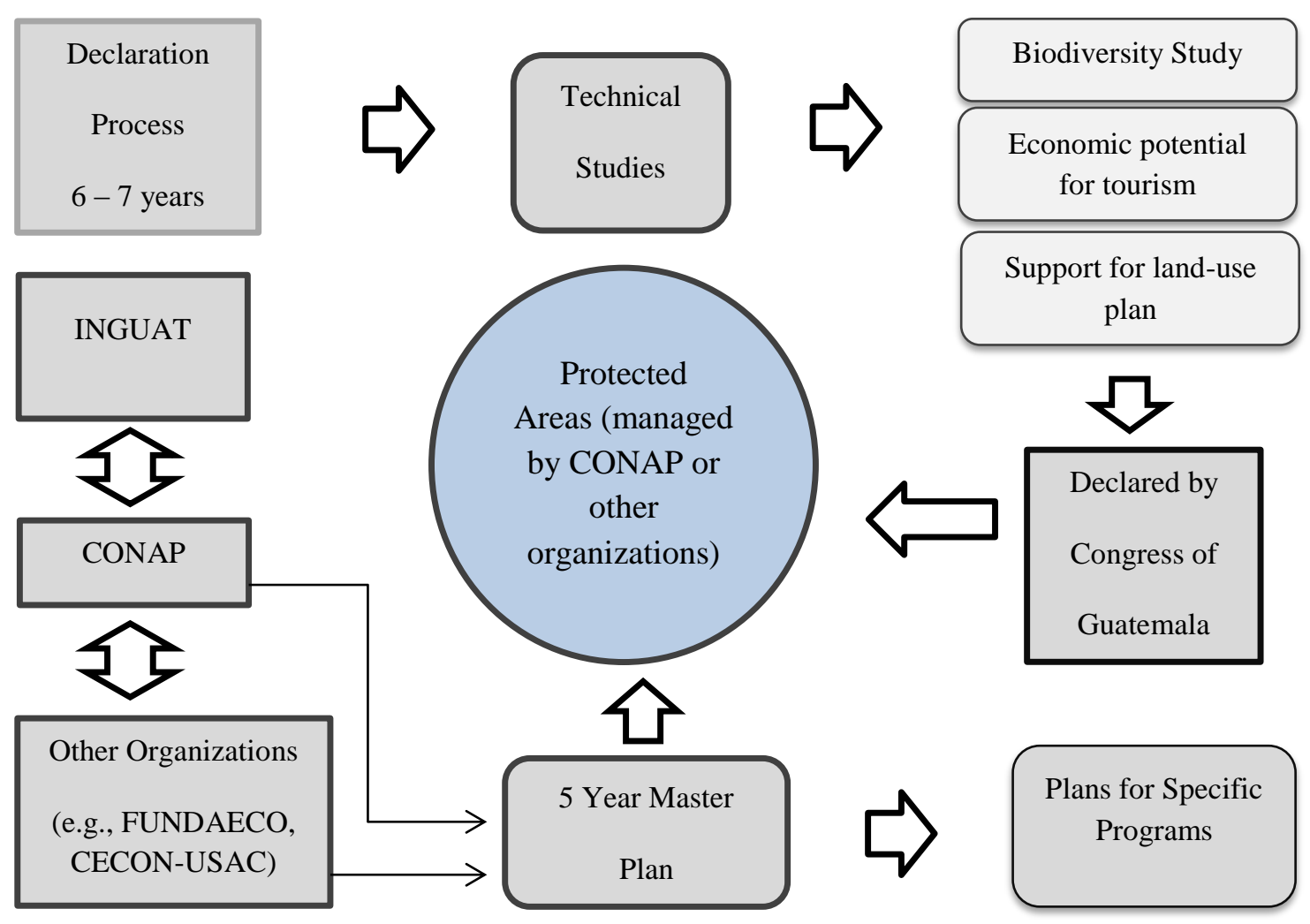

Figure 16 Overarching management and planning processes for the protected areas in Izabal.

INGUAT does not directly manage protected areas, but instead coordinates with other institutions like CONAP to promote developed tourism products (R5). CONAP on the other hand either directly manages the parks (R2) or provides administrative support to smaller-scale organizations for managing visitors (R6). Recently, the region of Lake Izabal and Rio Dulce has been given the moniker "Conservation Coast" as an umbrella term as the region is not managed by a single entity (R1). Decision-making at the community level is described in section 4.5.

The idea, as put forth by a key stakeholder, is that the designation of a protected area "does not compete with other development projects...but rather for them to be complementary" (R2). However, economic capacity, technical capacity, political support and social support from the 
communities are needed in order to move forward with the establishment of a protected area (R2). Thus, the key informants attempt to work with communities and in the protected areas to manage economic, social, and environmental impacts brought on by a lack of governmental support and tourism development, which in turn provides motivation to conserve the natural environment. The natural environment serves as a means for economic survival for the people who live in the communities within the protected areas. Even though protected areas are perceived in a positive light, in an interview with an informant from CONAP it was stated that the debate over the effectiveness of protected areas as a mechanism for the conservation of natural resources is ongoing as there may be other options (R6). The options were not specified.

\subsection{Influences on Communities' Sustainable Development}

The perspectives of the stakeholders have aided in framing the perceived roles of communities but have also provided insight into influences management and planning decisions have had on communities and their sustainable development. The interviews with the key stakeholders revealed that the communities are viewed as a source of major environmental pressure for the protected areas because of the growing population (R1; R2; R3; R6). This growth is perceived to create issues of land encroachment, deforestation, and land-use change for subsistence agriculture and dwelling construction.

When queried on the main environmental pressures the protected area may be experiencing, the key informants responded by identifying human presence in or around the area as the main cause. The community member, however, responded differently by stating that unemployment is the main source of environmental pressure in the community (R4). While no further detail was given on this matter, it was revealed that illegal logging within the community was an ongoing 
issue stemming from the dependence on the natural resources (Fieldnotes, July 13, 2013). Additionally, deforestation was presently occurring to clear land for subsistence agriculture (Fieldnotes, July 13, 2013). Table 11 lists the responses given to sources of environmental pressure as well as any follow-up issues and impacts such pressure has had within the protected areas.

Table 11 Environmental pressures affecting the protected areas in Izabal

\begin{tabular}{llll}
\hline $\begin{array}{l}\text { Main pressure } \\
\text { identified }\end{array}$ & Follow-up issues & $\begin{array}{l}\text { Impacts due to sources of } \\
\text { pressure }\end{array}$ \\
\hline R1 & Human presence & $\begin{array}{l}\text { Invasions within the core zone of } \\
\text { Cerro San Gil }\end{array}$ & $\begin{array}{l}\text { Deforestation caused by } \\
\text { subsistence agriculture }\end{array}$ \\
\hline R2 & Increase of families & $\begin{array}{l}\text { Lack of government support to } \\
\text { enforce rules and regulations }\end{array}$ & $\begin{array}{l}\text { Construction of dwellings in } \\
\text { restricted areas }\end{array}$ \\
\hline R4 & Unemployment & $\begin{array}{l}\text { Poverty brought on by } \\
\text { unemployment }\end{array}$ & $\begin{array}{l}\text { Pressure on natural resources } \\
\text { areas }\end{array}$ \\
\hline R5 & Land-use change & $\begin{array}{l}\text { Cattle farm expansion and climate } \\
\text { change }\end{array}$ & $\begin{array}{l}\text { Deforestation and illegal } \\
\text { extraction of biodiversity }\end{array}$ \\
\hline R6 & Monoculture farms & Population growth & Contamination of water bodies \\
\hline
\end{tabular}

In the case of Cerro San Gil, the human presence was referenced in terms of the number of communities present in the area, which total 40 (R1). The increase of families in the protected areas, caused by the high "birthrate", was described as "one of the greatest threats" and "significant" (R2). Population growth was also stated as a major cause of environmental pressure because of its effect on land occupancy via selling and purchasing land to support increasing family populations (R3). Communities within the protected areas, because of uncontrolled 
population measures, are seen in a negative light as the main cause of land-use changes, deforestation, and the overall exertion of pressure on the natural resources. Nowhere in the responses, however, were tourists specifically mentioned as the cause for such pressure and this could be due to the low number of tourists that visit the area. Only one respondent brought up tourist impacts via the improper disposal of waste water or solid waste and that efforts to curtail such impacts through public use plans are needed (R5).

The lands on which these communities are established are important because tourism attractions exist on community-managed property in Izabal. Attractions are nature-based and include lagoons, rain forest, hot springs, beaches, and spots for viewing wildlife, such as crocodiles and manatees (CONAP \& FONACON, 2004; CONAP et al., 2006; Ixcot Yon, 2005). Even so, tour operators prefer to send tourists to more popular tourist destinations within Guatemala, such as Antigua or Lake Atitlan. This results in a lack of support for community-based tourism and small visitor numbers. The lack of support serves to heighten unemployment and poverty, among other issues, within the communities in the protected area, resulting in a need to extract resources from the land.

As previously discussed, planning and management organizations have been involved in efforts to curtail environmental pressure on the natural resources through community involvement efforts. These efforts include employment opportunities in the form of employing local guides, which Chocon Machacas and Cerro San Gil offer (see Table 4). Communities within Cerro San Gil participate in decision-making processes that permits them to voice their concerns regarding various development projects, but are not allowed to vote on them (R1; R2). It was not made 
clear in the interviews if communities within Rio Dulce National Park can do the same, but according to the master plan, community involvement is limited and is designed to be carried out for three years within the five-year timespan, from 2005 to 2010 (CONAP \& FONACON, 2004). No such community participation plans are present in Chocon Machacas (Ixcot Yon, 2005).

Another strategy that has been undertaken is to educate the communities on conservation. As stated by the community member, the solution to improve the protection of the environment is to "educate people and give them the tools...in order to survive" but added that incentives are also needed (R4). The community member also stated that "through all the knowledge of tourism...knowing what we are doing...we can improve what we have around us," referring to tourism as a vehicle for education and as a means to maintain an ecological equilibrium between human beings and the environment (R4). While the education strategy is seen in a positive light, its effectiveness is challeneged by community members, presenting obstacles to tourism development and environmental conservation. In the case of Cerro San Gil, for instance, bird monitoring is viewed as a means to simply take care of birds or an excuse to watch birds (R1).

This generates conflict among local people because they feel it is a waste of park resources (e.g., budget) and that it does not benefit anyone (Fieldnotes, July 12, 2013). In order to reverse this trend, environmental education programs are set up in the site of Las Escobas for children of the surrounding communities with the objective to transfer knowledge to a younger generation, such that they apply that knowledge and, at the same time, influence the older generation to change their behaviours and attitudes (Fieldnotes, July 12, 2013). Park plans for Rio Dulce and Chocon 
Machacas both have education objectives within their schemes for management, but are not as specific as Cerro San Gil (CONAP \& FONACON, 2004; CONAP et al., 2006; Ixcot Yon, 2005).

If land-use change is allowed to occur and the natural resources are extracted, then tourism and visitation have the potential to be negatively impacted because the driving force of attraction to the sites, the natural environment, is diminished. At the same time, the communities need tourism because it serves as an alternative method to generate income. The planning and management institutions serve to aid communities in lessening environmental impacts but at the same time acknowledge that regulations and enforcement are needed to control human presence and populations within the protected areas. The government's role as a support mechanism to establish sustainable tourism development policies in Izabal is lacking, particularly in terms of management and financial support, which hinders development at the regional level.

\subsection{Identification of Vulnerable Areas through GIS}

Examining the perceived impacts tourism and communities have on the environment is important in determining conflicts and possible solutions. A geographic information system (GIS) is utilized here to spatially represent vulnerable regions within the protected areas in the study. The identification of vulnerable regions is conducted using information pertaining to sources of environmental pressure and conservation work, as identified by the key stakeholders in the

earlier sections of Chapter 4. The GIS results can be utilized as a decision-making aid for planners and managers in reallocating resources to vulnerable areas within the protected areas. 
The organizations themselves have utilized GIS for a few applications that relate to issues discussed previously. One such application was the spatial mapping of land ownership and categorizing it based on inherited, private, or community property, which served to address issues of land tenancy (R2). A great deal of time is invested in gathering those data and mapping them, as the work is very specific (R2). Another application of GIS noted by a key informant was its use to inform and generate a "Plan for Conservation of Areas" (R3). No further detail was provided. Two main elements were utilized in creating this plan: the cultural elements directly related to the Maya culture and the natural resources of the area (R3).

From the interview responses, three main themes related to the protected area's vulnerability are offered; 1) human presence within the protected area, 2) land-use change and encroachment, and 3) the need to conserve and monitor certain species, such as birds and amphibians. These three elements are recurring themes throughout the study, and hence are used as the layers for the overlay analysis. The first layer utilized is a population count for the communities within the protected areas. Using the shapefile for communities provided in the NREL dataset, population numbers for each community within each of the protected areas is displayed using graduated symbols, as shown in Figure 17. The range of population categories is divided using equal intervals. Population densities for the communities are not displayed because the size, in terms of area, of a community may not be exact due to a lack of specific land data. The boundaries of the communities are also not known and may produce misleading data. This representational format as shown in Figure 17, however, has the potential to show how communities with higher populations may expand outwards in the future. 


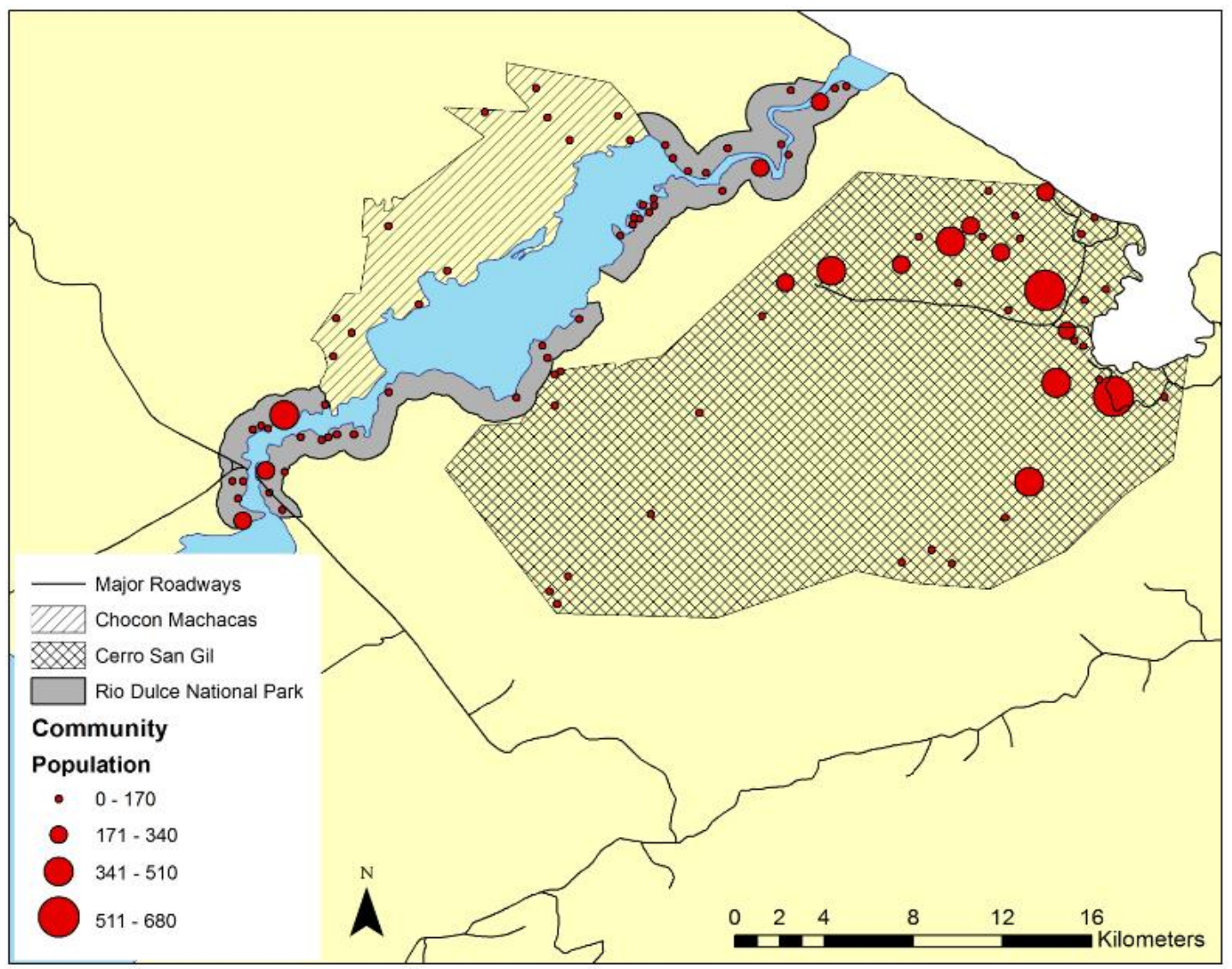

Figure 17 Layer 1 showing population size for the communities within the protected areas.

The first layer shows greater population numbers towards eastern Cerro San Gil. This may be explained by access to major roadways. In Rio Dulce National Park, communities with greater populations are located in the western region of the protected area. Chocon Machacas shows no significant population numbers and a lower number of communities when compared to the other two protected areas. Indeed, it appears that Cerro San Gil contains a greater number of communities with high population counts. Highly populated areas were selected to be greater than 341 as selecting a range of 511 to 680 reduced the number of communities included in the overlay analysis. Moreover, communities that may be impacted by other factors (e.g., proximities to roads or rivers) may be omitted if the range of population count is limited. 
Layer 2 shows land cover for the protected areas (Figure 18). The shapefile for land cover included categories and subcategories of land cover. Subcategories were utilized in this case because they increase the precision of the final overlay analysis as the larger areas are further categorized into smaller units. From Figure 18, it can be seen that Cerro San Gil is mostly covered by deciduous forest, followed by annual cultivations and secondary forest. Rio Dulce National Park mostly contains a mix of natural pasture and deciduous forest while Chocon Machacas is primarily covered with humid forests and marshes. Forest covers are vulnerable due to threats of deforestation and human presence, as mentioned in the interviews. It is not clear in the dataset, however, to what other cultivations refers.

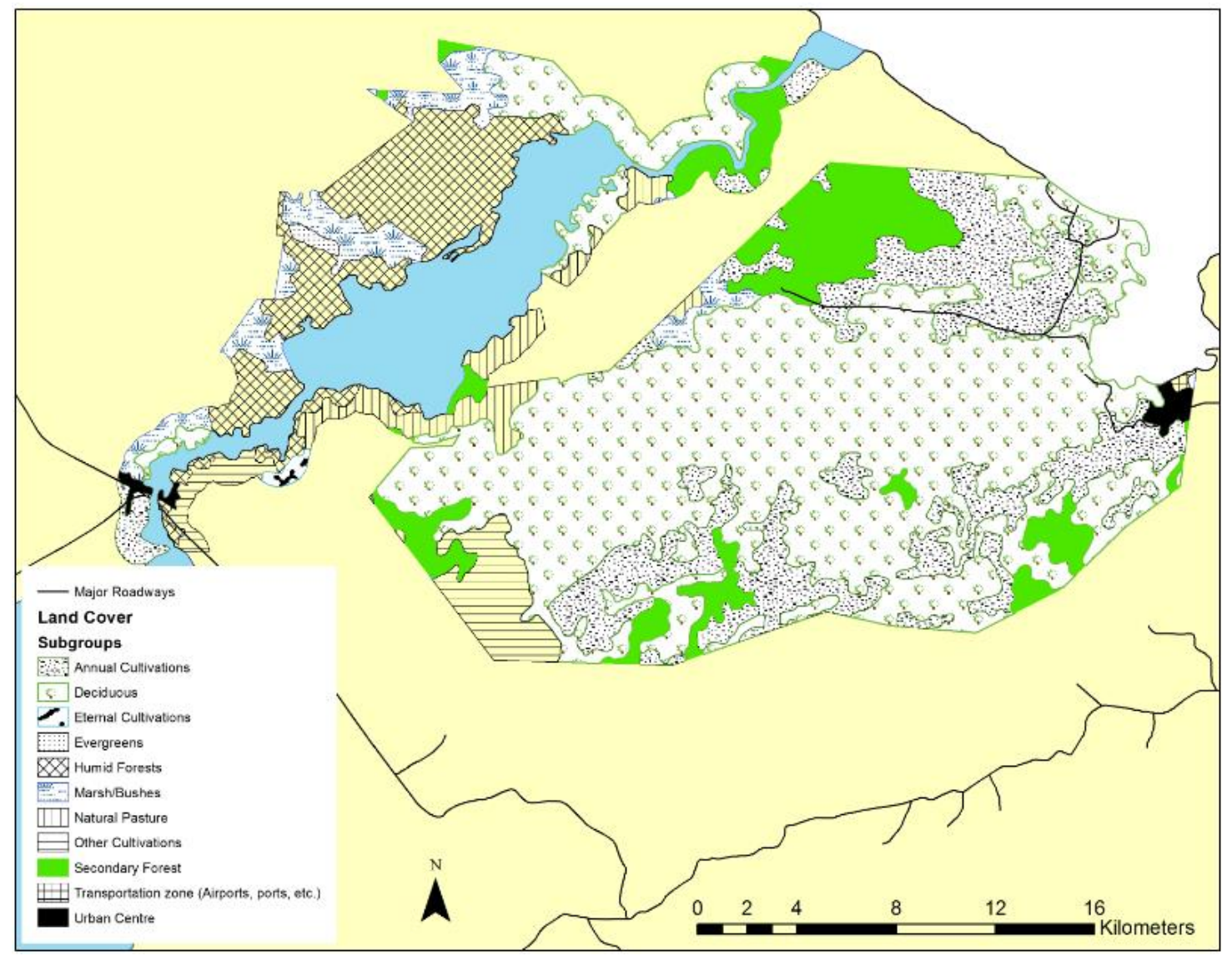

Figure 18 Layer 2 showing land cover within the protected areas. 
Layer 3 shows the biodiversity of the protected areas in terms of the number of species of birds, amphibians, reptiles, and mammals per square kilometre that have been reported in each area (Figure 19). Using the master plans, the number of species were retrieved, input into a spreadsheet, and integrated into GIS via a join function with the attribute tables for the protected areas. The density of species was limited to forested areas, which included deciduous, evergreen, humid, and secondary forests, as well as marshes, and covers large tracts of the protected areas (Figure 18). While bird and amphibian species were initially mapped because they are a main line of conservation work, other species were included because they are a part of important conservation efforts.

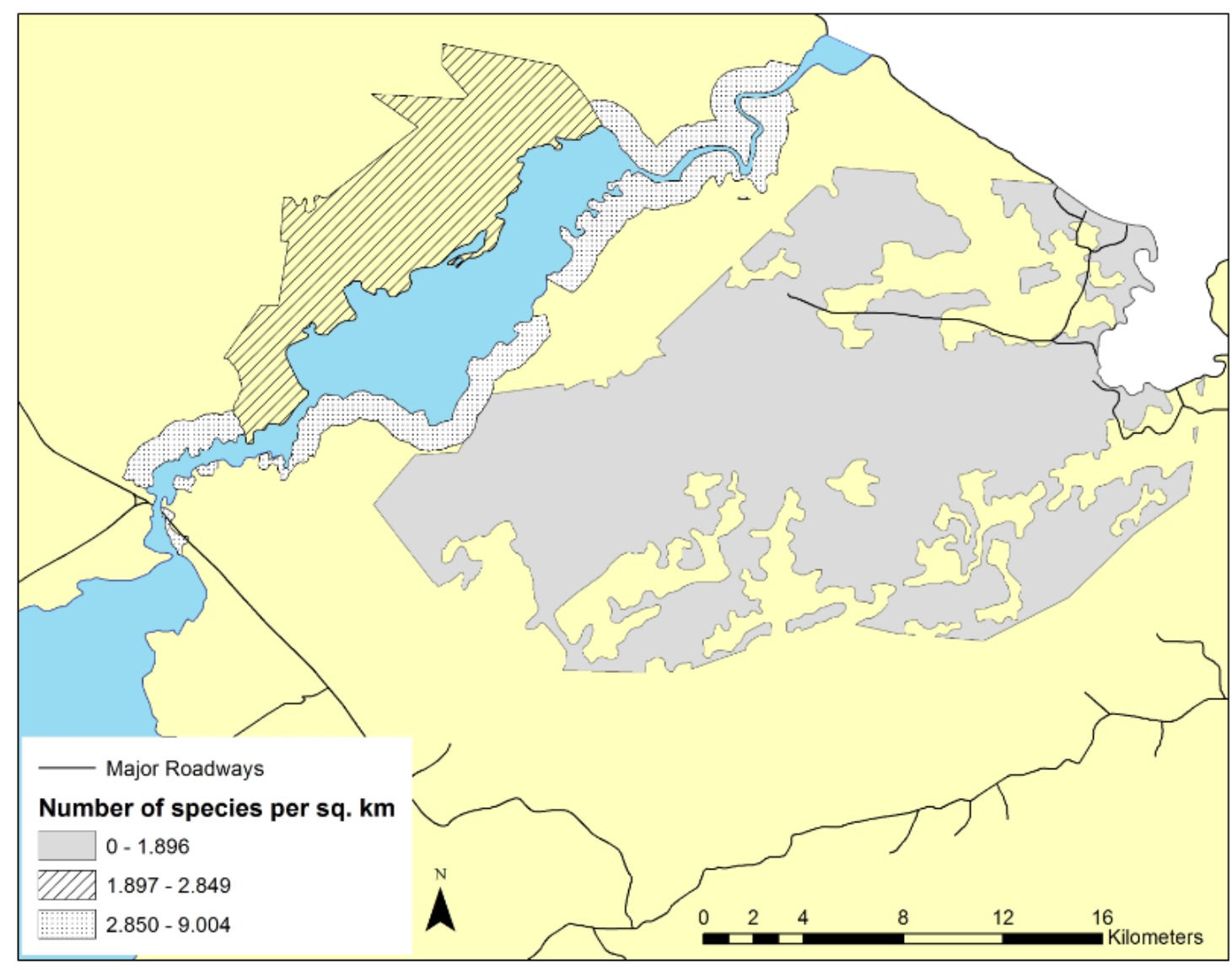

Figure 19 Layer 3 species diversity per square kilometre 
From Figure 19, Rio Dulce National Park has a greater diversity of species, ranging from 2.850 to 9.004 species per square kilometre and this but this may be due to the smaller area of the park. Rio Dulce National Park is measured to be 13,000 ha while Cerro San Gil's area is 47,433 ha (see Table 2). Chocon Machacas has the lowest area, but has higher species diversity than Cerro San Gil. Forested areas were selected as the unit of analysis for this layer because they are under threat from deforestation due to human presence and population growth. Marshes were also included in this unit of analysis because of their importance in maintaining significant ecosystems and species. Moreover, forests and marshes act as habitats for various recorded species in the protected area, specifically birds.

The map of communities with high population numbers (Figure 17) and the map of land cover (Figure 18) were overlaid using the intersect function in ArcGIS to produce a map of vulnerable zones within the protected areas (Figure 20). Specifically, the vulnerable zones were determined by intersecting the maps of communities with a population greater than 341 , due to population growth concerns, and forested land cover, due to issues of deforestation. The species diversity map was not used in the overlay but rather was clipped to the protected areas in Figure 19 in order to show where these vulnerable areas occur in the context of biodiversity. The map (Figure 20) shows that there are vulnerable zones in the eastern region of Cerro San Gil and in a zone in the western region of Rio Dulce National Park. There are none in Chocon Machacas. Rivers were added and the major roadways emphasized in Figure 20 to indicate their location to the vulnerable zones. 


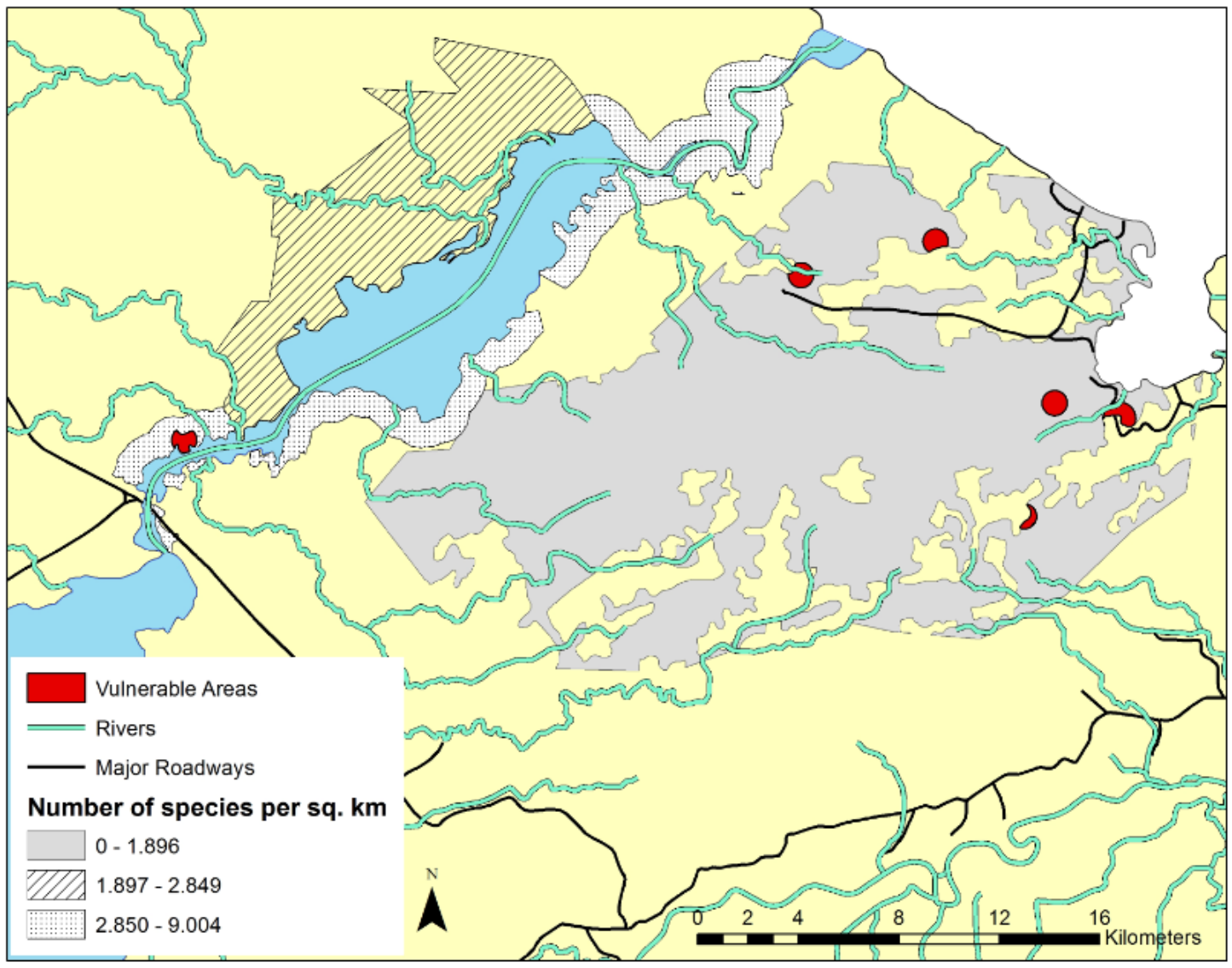

Figure 20 Vulnerable areas and species diversity

In Cerro San Gil, most of the vulnerable zones are either traversed by a major roadway or river, or are in close proximity to both features. This has implications for the potential increase of pressure on water, which is of importance as a source of drinking water for communities within the protected area and surrounding towns, such as Puerto Barrios, located just outside of Cerro San Gil. In the eastern region of Cerro San Gil, a major roadway crosses a vulnerable zone and comes close to another, while a river cuts across the latter. The vulnerable zone in Rio Dulce National Park is situated by the river, Rio Dulce, and is located in an area with a high species density, which has implications for increasing stress on ecosystems. 
Figure 21 shows where the vulnerable zones are located in terms of land cover. In Cerro San Gil, two zones are located in secondary forest regions, while the remaining three are located in deciduous forest cover. In Rio Dulce National Park, the vulnerable zone is located within a deciduous forest cover, adjacent to a marsh. These vulnerable zones are important because of the impact deforestation is having on the protected areas.

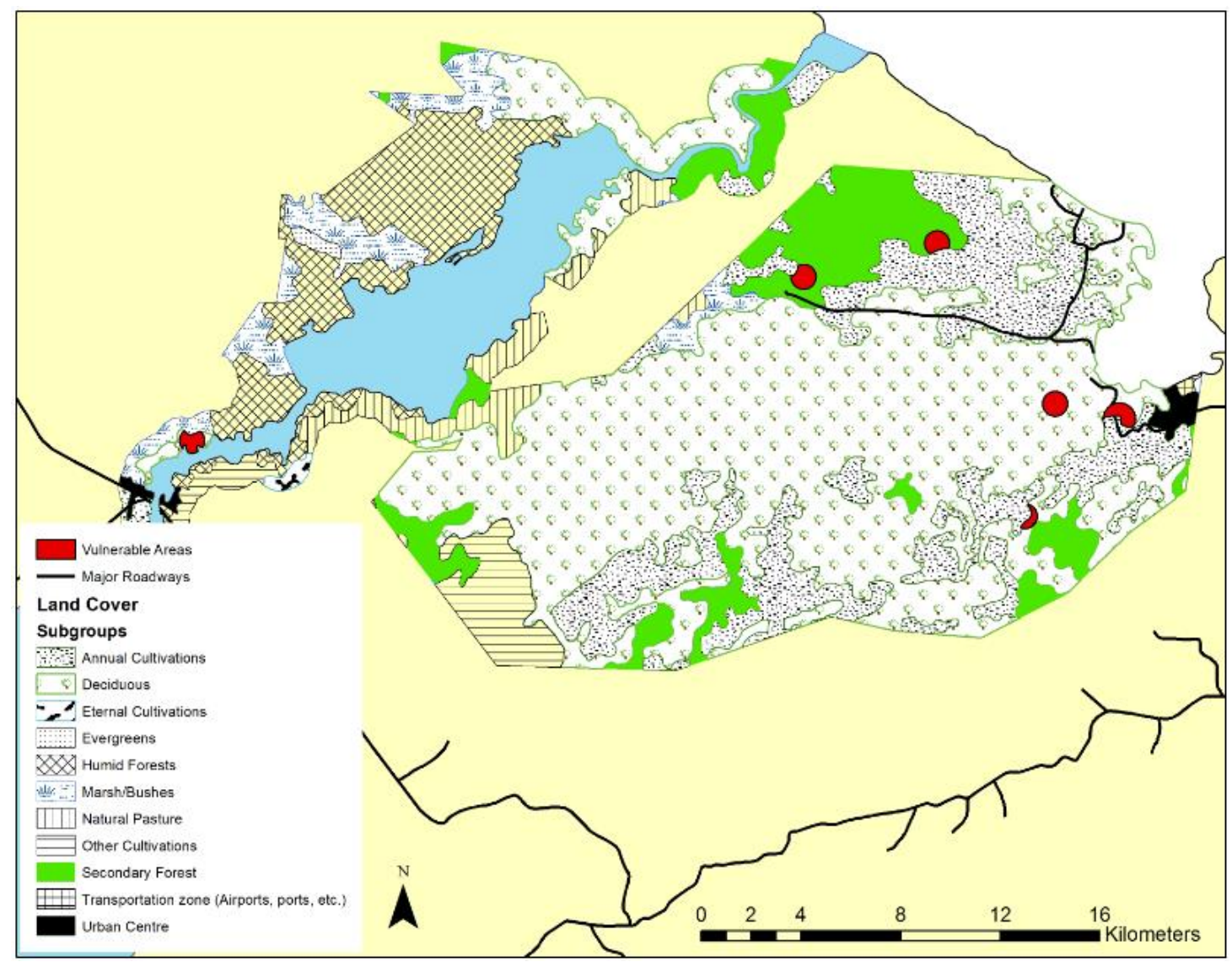

Figure 21 Vulnerable areas and land cover

Tourist attractions in the protected areas serve to increase environmental pressure for the various natural resources present in these areas. Unsustainable tourism development will only increase the number of vulnerable zones and these will also become increasingly difficult to manage. The 
interviews with key stakeholders have pointed to the need for governance for the development of policies to enforce rules in the protected areas that allow greater control over land encroachment and population increase. Environmental conservation and the protection of natural resources are recognized for their importance in supporting fragile ecosystems and biodiversity, but also because tourism in Izabal is driven by the natural environment. An alternative livelihood through sustainable tourism is perceived as a solution to reducing dependency on the natural resources. The development of sustainable tourism, however, requires clear objectives related to visitor management, community participation, and governance. These themes, among others, are discussed in Chapter 5. 


\section{Chapter 5}

\section{Discussion, Recommendations, and Conclusion}

\subsection{Introduction}

This chapter highlights the results, connections to the literature, and contribution of the findings. The discussion and recommendations are divided into themes regarding institutional support and collaboration, community development, education, and visitor management within a sustainable tourism development context. The GIS maps are also discussed with regards to their implications for management decisions and the need for optimal data to move forward with GIS-related studies of the protected areas. A summary of the results is given followed by the contribution of the research and how it may be beneficial to tourism researchers and those in planning and management fields. Future research initiatives on sustainable tourism development in Izabal, or in Guatemala in general, are proposed. Finally, the conclusion summarizes the main findings of the research, combining the recommendations and future research initiatives that may aid planners and managers in overcoming difficulties to developing sustainable tourism initiatives.

\subsection{Discussion and Recommendations}

The perspective that protected areas are very important for tourism in Guatemala is shared by all key stakeholders in this study. Yet, its importance is undermined by the lack of support to: sustainable tourism development in this region; community development; and measures to ensure the protection of the environment. 


\subsubsection{Institutional Governance and Collaboration}

The meshing of tourism with other sectors and the decentralized approach within sustainable tourism development is a prerequisite to ensuring long-term sustainable tourism objectives (Vellas, 2002). This is because support and collaboration with other sectors is viewed as a mechanism for implementing solutions and a way to generate financial and educational support (Drumm, 2013). In Izabal, other non-tourism sectors have yet to mesh with the tourism industry. One such example involves the lack of partnerships between public and private entities, as is the case in Rio Dulce National Park, where private tour operators do not pass on any revenue to the national park or to other sectors of the tourism industry (R2).

Aside from national organizations, problems remain in coordinating and regulating tourism with other organizations on a departmental (i.e., state/provincial) level. For instance, the Authority for the Sustainable Management of Rio Dulce Watershed (AMASURLI), which was established in 1998 by the Government of Guatemala to protect tourist attractions in the Lake Izabal and Rio Dulce region, remains a consultative organization with very little power (GWP \& INBO, 2009). Additionally, this organization is not recognized by other stakeholders in this region, hindering its ability to aid in the development of tourism (Binimelis et al., 2007). Moreover, as the findings of the study show, INGUAT is not directly involved in on-the-ground management of the protected areas. These disjointed organizational efforts to collaborate are significant as fragmented institutional governance stalls progress towards sustainable development (Sneddon et al., 2006). 
Governance has been recognized as a key factor for the effective management of protected areas (Dearden et al., 2005). Indeed, the Government of Guatemala has taken action to strengthen the governing powers of INGUAT, albeit in a sluggish manner (Muñoz, 2013). The problem is compounded as CONAP faces a similar issue in that its budget to support the protected areas effectively remains constrained. Developing policy is essential to giving these entities greater governance power to enforce laws and rules. State intervention for Peru's Inca Trail, in the form of policy creation and implementation, allowed governing tourism bodies to enforce restrictions on tour agencies in order to minimize environmental degradation (Maxwell, 2012). In the case of Izabal, it is recommended that policy development focus on allocating sufficient financial resources to public tourism-governing bodies and to give them greater control and oversight of tour agencies. This should include requirements for private tour operators to hold permits that allow them to operate and to be held accountable for unsustainable environmental practices.

Stronger collaboration is touted as a solution because the benefits of collaboration have been noted to support long-term sustainable development (Dearden et al., 2005; Vellas, 2002). Through the interviews, it was found that INGUAT, and to a lesser extent CONAP, collaborate with other agencies for the primary objective of promoting tourism. These agencies include CAMTUR and cruise-related organizations. The most recent case comes from INGUAT, whereby a new tourism marketing campaign was launched in 2014 called "Lecciones de Vida" (Life Lessons) that aims to leave a lasting impression on tourists about the life lessons Guatemala can teach them (Coronado, 2014). This campaign, which cost USD 3.8 million, was received with skepticism by tour operators, doubting that media exposure will be effective in 
generating more tourists due to a lack of developed markets and tourism information, particularly on the website of INGUAT (Coronado, 2014).

Therefore, it is recommended that stronger collaborative pathways be established between the main tourism governing bodies and regional and local organizations. INGUAT and CONAP should provide a greater level of support to the protected areas by collaborating with NGOs and local organizations, such as AMASURLI and FUNDAECO, to develop and implement sustainable tourism initiatives prior to encouraging tourists to visit through advertising campaigns. This includes, but is not limited to making Rio Dulce National Park and Chocon Machacas a priority for sustainable tourism development, establishing monitored access points throughout the protected areas, establish a controlled private tour operator network, and ensure community members are part of the collaborative efforts.

Tourism initiatives in Ecuador's Podocarpus National Park may be utilized as an example due to the park's low visitation, which is much like the case in the protected areas in Izabal. Because Podocarpus is visited by a low number of tourists, it provides an opportunity for park planners and managers to address gaps in tourism development before looking to increase tourist arrivals (Moran-Cahusac, 2009). Addressing these gaps include establishing an information distribution platform, developing a coherent signage plan and trail system, and ensuring the participation of community members such that they receive the benefits of tourism (Moran-Cahusac, 2009). By developing tourism in this manner, impacts on the natural resources can be addressed in a proactive manner that seeks to minimize natural resource impacts and ensure benefits are 
received by the communities rather than being reactive, when tourist visitation is greater and hence difficult to control and manage under sustainability principles (Moran-Cahusac, 2009).

\subsubsection{Community Development}

The communities located within the protected areas present challenges for the development and management of tourism. The way in which communities are governed and included in decisionmaking processes can be modelled on a continuum of governance possibilities, ranging from completely government-managed areas to community-managed areas (Figure 22) (BorriniFeyerabend, Kothari, \& Oviedo, 2004). The continuum also shows the possible interactions with communities, ranging from ignoring and repressing the interests of community members to giving them full authority over the protected area (Figure 22). RDNP, Chocon Machacas, and Cerro San Gil are represented on this continuum based on the findings.
Government-managed
Co-managed
Community-
protected areas
protected areas
conserved areas

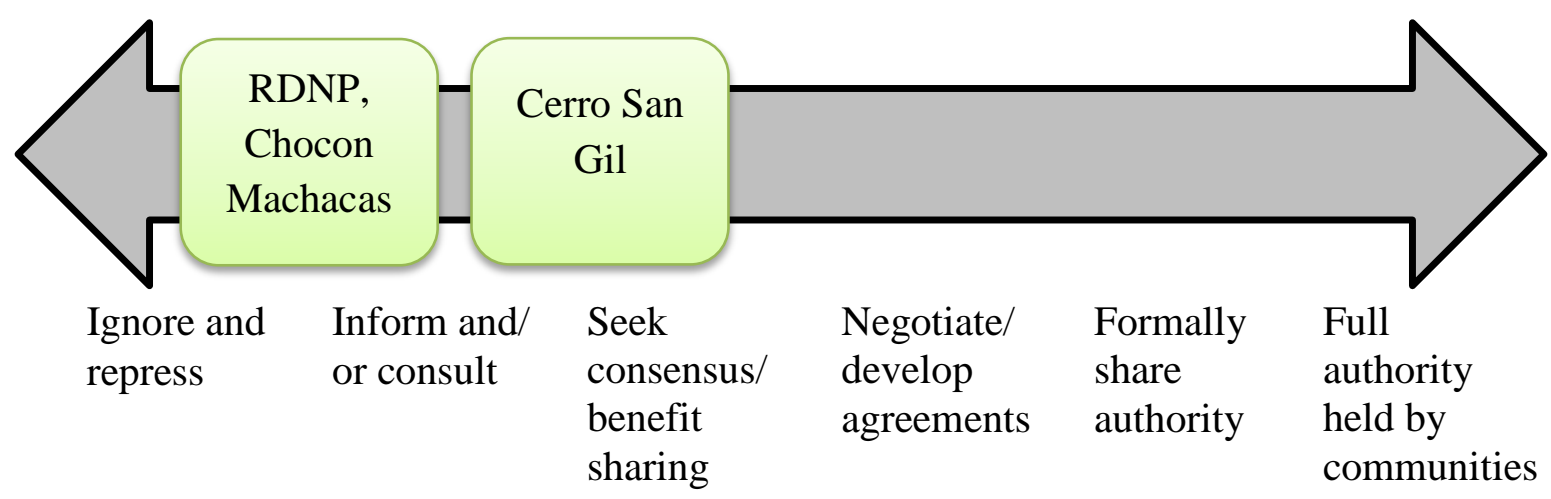

Figure 22 Continuum of governance possibilities in protected areas. Adapted from BorriniFeyerabend et al. (2004). 
Communities within Cerro San Gil have a voice because they are able to consult with FUNDAECO and other organizations regarding developmental issues but are limited in that they have no voting power to make decisions. Thus, according to the continuum of governance possibilities (Borrini-Feyerabend et al., 2004), because the communities are consulted regarding issues and decisions, and benefits are shared through educational and employment initiatives, some level of co-management is occurring but falls short in actively seeking consensus and developing agreements with communities.

With respect to the communities within Rio Dulce National Park and Chocon Machacas, governance falls into the government-managed category, with full-authority and responsibility over the protected area (Borrini-Feyerabend et al., 2004). In this case, CONAP manages both RDNP and Chocon Machacas, which is also partly managed by CECON-USAC. According to the continuum of governance options, government bodies may ignore the interests of local communities or, at best, inform communities about issues and decisions (Borrini-Feyerabend et al., 2004). Even so, a degree of "tokenism," or minimal effort, is applied by the managing organizations to inform and consult with communities and hence, communities lack the power to ensure that their concerns are heeded and implemented (Arnstein, 1969). As Okazaki (2008) stipulates, actual empowerment involves a greater level of partnership and citizen control such that the communities are able to control tourism development. This is currently not the case in the protected areas in Izabal.

The Nature Conservancy example showed that, by assuming that the local residents were the main threats to the biodiversity in the Lake Atitlan region, they were excluding an important 
component of ecotourism development: the local people (Wallace \& Diamente, 2005). Changes were made to TNC's efforts to develop ecotourism in Lake Atitlan, shifting from placing blame on communities for environmental degradation to ensuring that local voices were heard and brought into discussions of tourism development on a permanent basis (Wallace \& Diamente, 2005). Tourism in Santa Catalina, Panama, is another example where business owners perceived the local residents to have unintended, yet negative effects on the environment and society (Drumm, 2013). Similarly, in this study, the inhabitants of the protected areas are viewed as the main cause for environmental degradation but little focus is placed on the negative impacts tourists can have on the protected areas. This occurs on variable scales for Rio Dulce, Chocon Machacas, and Cerro San Gil, with the latter having greater interaction with local communities.

By excluding the local communities, enforcing managerial initiatives and conservation policies becomes extremely difficult (Andrade \& Rhodes, 2012; Aswani \& Weiant, 2004). Empowering local communities through participation not only makes use of their knowledge and customary rights, but also makes them a part of organizational decision-making processes (Aswani \& Weiant, 2004; Okazaki, 2008). Moreover, securing long term environmentally-improved tourism services can be best achieved through human investments within the context of environmental management as well as through quality improvements in alliance networks or inter-firm cooperation (Peters \& Weiermair, 2002).

Human investment initiatives are occurring in Cerro San Gil through community involvement and environmental education on behalf of FUNDAECO. A meeting held during the visit to the site of Las Escobas demonstrated this involvement, whereby community women gathered to 
discuss local issues (Fieldnotes, July 12, 2013). Unlike Cerro San Gil, local communities within RDNP and Chocon Machacas do not appear to have much involvement in planning and managing processes. For instance, locals providing private tour services do not coordinate with tourism governing bodies. Hence, it is recommended that investments be made by FUNDAECO and CONAP to involve communities to a greater extent in decision-making and development processes. Moving towards formally sharing authority between larger organizations and community stakeholders should begin by giving local people the power to vote on decisions because it influences people's willingness and ability to engage in tourism (Salazar, 2012).

Benefit sharing in the form of educational services and employment opportunities generated through tourism (e.g. local tour guides) are steps that can be initiated by CONAP and INGUAT by providing financial or technical support to allow such investments. Initiatives already in place

in Cerro San Gil can be applied to the protected areas in the Lake-Izabal region. By making communities a part of organizational decision-making processes, it also becomes easier to enforce managerial initiatives and conservation policies (Aswani \& Weiant, 2004). Additionally, community members can use their local knowledge and customary rights to sustainably develop tourism on community-owned land without infringing on their rights to use that land.

\subsubsection{Education}

Generating alternative income opportunities must also involve capacity building, which Andrade and Rhodes (2012) state plays an important role in ensuring long-term sustainability. Environmental education and technical training in aspects like financial management are some examples of capacity building that can be undertaken by the local communities (Andrade \& 
Rhodes, 2012). In a Canadian example, it was found that quality educated guides and staff members were a key ingredient to business success (Hopkins \& Price, 2002). Environmental education is important because it allows people to develop the attitudes, knowledge, and skills in order to enable people to participate in environmental politics by facilitating a greater understanding of environmental issues (Hopkins \& Price, 2002).

This is a strategy being carried out in some of the protected areas in Izabal. Staff at Cerro San Gil is actively involved in educating children because it promotes behaviour change in them. In addition, it is a strategy that works in reverse to influence and perhaps change the behaviour of elders via the children and youth. Environmental education for youth instills a sense of environmental and social responsibility in hopes of forming habits that reflect environmental conservation (Drumm, 2013). By gaining a greater understanding of environmental issues, community members will also be able to participate in decision-making procedures (Drumm, 2013). Furthermore, education can serve the local people in the long-term by potentially generating well-informed local guides to drive tourism success (Hopkins \& Price, 2002).

Education, however, requires time and a considerable amount of support from the government to plan curricula, have the necessary staff and budget to carry out such objectives, and to inform community members of ongoing education initiatives. The training of guides serves as another example of an initiative that requires time and governmental support for educational and training materials. Recommendations include that teaching resources be allocated to the organizations responsible for managing the protected areas in this region. Since FUNDAECO has taken initiatives in this regard (in Cerro San Gil), CONAP should play a more active role in providing 
education services in RDNP and Chocon Machacas. Support should be sought from INGUAT and government departments in education and development, such as SEGEPLAN.

Park plans should also include detailed educational plans that are intended to be carried out for the length of the plan's effective use. Currently, Cerro San Gil has detailed plans and on-going education initiatives compared to Rio Dulce National Park and Chocon Machacas. The costs associated with carrying out these objectives require a greater level of commitment and involvement from larger governing bodies, particularly INGUAT and CONAP, as well as education governing bodies in Guatemala. Again, collaboration among entities is presented as a solution to address challenges related to community development and, in this case, education.

\subsubsection{Visitor Management}

The protected areas in Guatemala have limited control in terms of visitor monitoring and the collection of fees, and this is usually the case for areas with multiple entrance points or inhabitants in the area (WTO, 2004). Cerro San Gil has at least two entrance points that are monitored, Las Escobas and Green Cove which are located on opposite ends of the protected area, but challenges remain in addressing community population growth and environmental pressure on natural resources. Conversely, Rio Dulce and Chocon Machacas have no control points to monitor visitors and have inhabitants living in the area, even in established attractions like San Filipe Castle (Fieldnotes, July 15, 2013). Establishing tourism infrastructure and means to control visitors may serve to reduce human impact from those who make use of the protected areas. 
Some common measures to reduce human impact include creating trails, signposting, and setting buffer areas with restricted access to the public (Collins-Kreiner et al., 2013). Approaches to managing impacts caused by tourists can take the form of area closures and setting up barriers. In Izabal, trails are available for all the areas in this study (see Table 4) but these established paths in Rio Dulce and Chocon Machacas are not readily visible or not as extensive when compared to the trails in Cerro San Gil. The establishment of a fee collection system in Cerro San Gil allowed for this infrastructure to be expanded and improved for tourists, to allow the control of visitor dispersal from sensitive water spring areas. Signs (Figures 13 and 14) have also been utilized, albeit with differing levels of effectiveness. It is recommended that signs be repositioned to be made clear and unobstructed, or that they be established in areas with no signage. Furthermore, trails must also be examined for their effectiveness in controlling visitor dispersal.

Rio Dulce National Park, claimed as an important destination in Izabal by representatives of the main tourism governing bodies, requires visitor management practices akin to those in Cerro San Gil. Resources should be redirected to establishing visitor management considering the level of importance the key informants perceive RDNP to be. It is recommended that clearly defined entrance and exit points be established in Rio Dulce National Park and Chocon Machacas. The locations of these access points should be determined prior to designing and implementing visitor fees. The town of Las Fronteras already acts as a gateway to RDNP and Chocon Machacas, and so creating an access point from here should be considered. This, however, requires the collaboration and cooperation of private tour operators, NGOs and governmental organizations, and communities to come to an agreement on such planning decisions. 
The implementation of visitor fees may achieve important management objectives particularly in managing area use and creating an attitude of respect for the area (Eagles et al., 2002). Methods to track payment, such as the use of tickets or hand bracelets, should also be considered as this is a technique utilized in other protected areas of Guatemala. Additionally, the recommendations made in section 5.2.1 may apply here in that private tour operators should be required to hold permits in order to operate in the protected areas. This also allows governing bodies to manage private tour operators and coordinate with them in order to achieve visitor and ecosystem management objectives. Moreover, it is recommended that considerations be made with regards to fee collection from tour operators in order to support financial functions in the protected areas. The low visitation to these protected areas currently provides planners and managers with an ideal opportunity to address these visitation management gaps.

\subsubsection{Environmental and Tourism Implications in Vulnerable Areas}

From the GIS-produced maps, zones of vulnerability appear to lie at the eastern end of Cerro San Gil and in one spot in Rio Dulce National Park (Figure 23). In Cerro San Gil, the communities within the vulnerable zones have higher population numbers than other communities located in the protected area, most notably on the opposite side of the area. A reason to explain this comes from the neighbouring town of Santo Tomas de Castilla and Puerto Barrios, which is located just

outside of Cerro San Gil (Figure 23). Specifically, Puerto Barrios' population growth and migration to the protected area have been cited as cause for environmental pressure in the protected area (R1). The estimated population of Puerto Barrios for 2013 is 106,722 (INE, 2013). This figure is much greater than the population of the communities inside Cerro San Gil. 
Furthermore, the zones of vulnerability are in close proximity to major roadways (Figure 23), which have been shown to cause environmental degradation (Joerger et al., 1999).

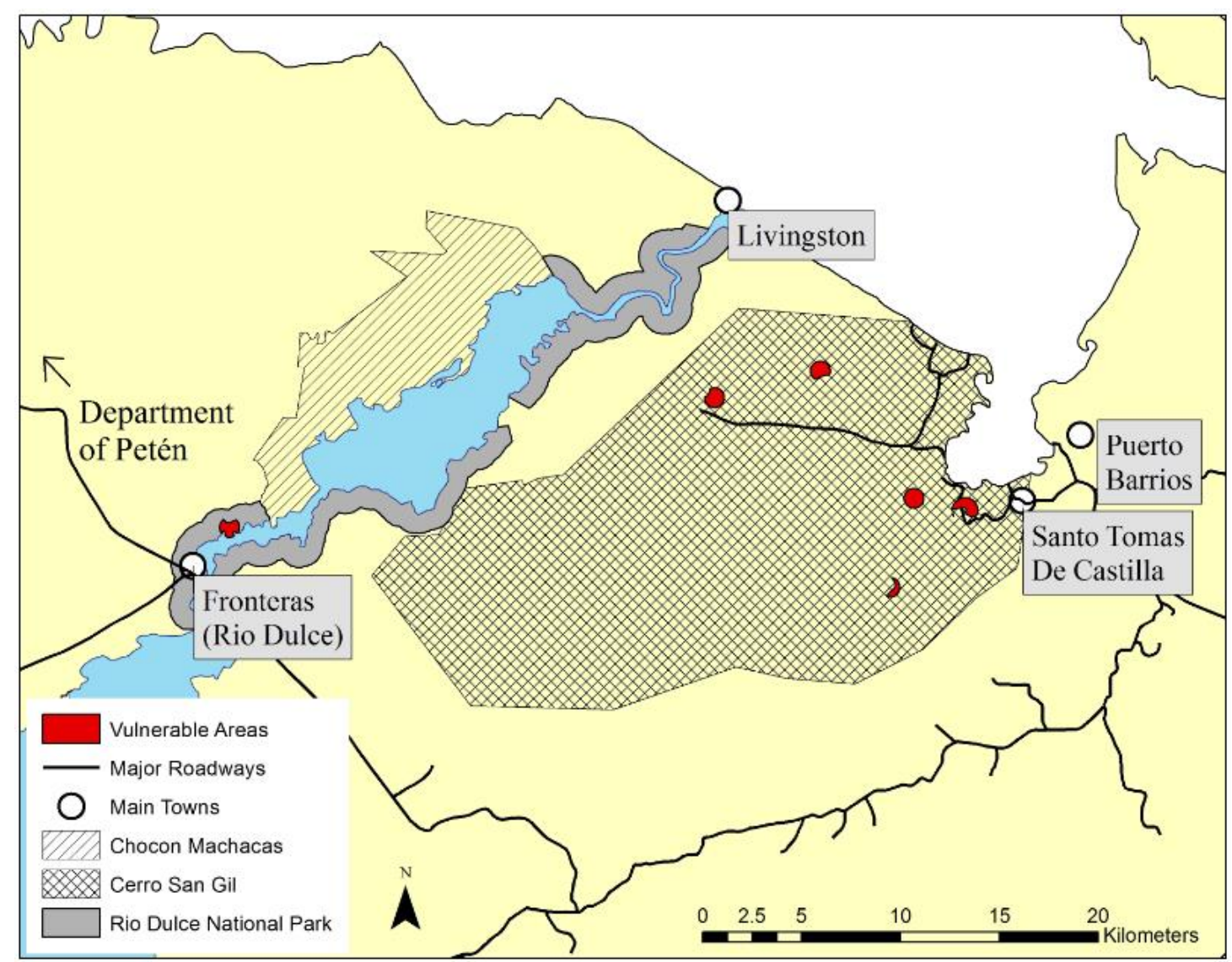

Figure 23 Summary map containing main towns around the protected areas

Within Rio Dulce National Park, the area of vulnerability lies in close proximity to the town of Las Fronteras, which as mentioned acts as a gateway to the protected area (Figure 23). In addition, this town provides services to those travelling through there, such as banks, hotels, restaurants, and general shops (CONAP \& FONACON, 2004). This town of Las Fronteras has a population of 3,974 (CONAP \& FONACON, 2004). Current population figures are not available from the INE. While much smaller when compared to the population of Puerto Barrios, the 
population of Las Fronteras remains higher than the nearby communities. The population growth of this town may also serve to explain the area of vulnerability. The road connecting Izabal to the department of Petén also cuts through Rio Dulce National Park (Figure 23) and certainly has an influence on the area's vulnerability.

It is recommended that these vulnerable zones be examined closer by FUNDAECO in Cerro San Gil and CONAP in Rio Dulce National Park. Studying the areas determined in the GIS analysis in detail requires updated population figures for the towns of Puerto Barrios and Las Fronteras. Visitor management must also be implemented in these zones either through the establishment of access points (in RDNP) or improved monitoring of visitors and local residents alike (in Cerro San Gil). This should be made a priority in order to plan for and manage population growth such that it does not greatly influence community growth and intrusion within the protected areas.

Issues of collecting and maintaining GIS data were mentioned in the interviews, and so performing extensive GIS studies may be difficult to carry out for smaller organizations. Hence, the maps and overlay results presented in this study serve to demonstrate how a GIS analysis may be carried out in the Lake Izabal-Rio Dulce region using readily-available data from sources such as the NREL. The nature of data utilized in this study also presented limitations for the analysis due to insufficient data for aspects related to tourism attractions, vegetation cover, and infrastructure. Touristic sites such as San Filipe Castle and Green Cove, for instance, were not mapped because that data were not in the datasets. 
Optimal data, data that would be ideal to progress GIS studies in this region, is required to explore various implications of sustainable tourism development in greater depth. Examples of optimal data include hotel locations, historic sites, established trails, vegetation cover that shows deforested areas, and local roads, within and around the protected areas. By obtaining these data, a comprehensive analysis can be carried out by generating various thematic layers, as opposed to the limited number in this study, and overlay them to determine a broad range of sustainable tourism scenarios. These scenarios can help guide potential solutions to sustainable tourism in greater depth as various components of sustainable tourism are taken into account.

Conducting and updating studies on land ownership and tenancy must be carried out in order to clearly delineate ownership of land. As mentioned in the interviews and in the literature, uncertainty with respect to land ownership has resulted in various issues related to a lack of community development and uncontrolled population growth (Gonzalez et al., 2002; Badurek, 2009). As such, allocating resources to address the issues presented in the final GIS maps (Figure 20 and Figure 21) can take the form of land tenancy studies. State intervention is required, however, as collecting data is both time consuming and costly. It also should involve the collaboration of the stakeholders impacted by land ownership concerns, including government organizations like SEGEPLAN, tourism governing bodies, NGOs, local organizations, and community members.

\subsection{Summary of Results}

Tourism in Izabal remains mostly undeveloped and underfinanced. The lack of financial support of governmental organizations has resulted in underdeveloped tourism services and the need for 
management support. Statements alluding to the premature state of protected areas management from INGUAT and CONAP both serve to reinforce the notion that much work remains to be done to develop sustainable tourism in Izabal. Tourists are redirected to popular destinations within Guatemala, which are extensively promoted by INGUAT through campaigns like VisitGuatemala. Tourists who visit Cerro San Gil, Rio Dulce National Park or Chocon Machacas contribute to income generation but the revenue remains mostly in the pockets of private tour operators, often with none going towards the protected areas. This is an implication of a lack of effective institutional collaboration and regulations to manage private tour operators.

The communities receive the impact of low tourist arrivals and improperly managed visitation that it makes it difficult for the communities to earn an alternative livelihood through tourism. This pushes the local residents to rely on the natural resources within the protected areas to meet their needs, placing pressure on the environment. In turn, the communities are perceived as an obstacle in the development of sustainable tourism because of the influence they have on the natural resources, which requires protection for both biological processes and ecosystems, and as a tourist attraction. This perspective of communities at fault detracts attention away from tourists and their potential to inflict negative environmental impacts in the protected areas.

By improving management and planning initiatives, tourist arrivals, and population control, community development and environmental conservation objectives may be better addressed. This can be approached through several means as reported in this study. Environmental education can serve to change potential environmentally destructive behaviour but is only accomplished if such an investment is made by the organizations for the protected areas. 
Providing employment opportunities through jobs as local guides and food vendors contributes to alternative income generation. Visitor management through the establishment of access points, certified tour operators, and clearly defined trails and restricted zones aid in managing tourists but also in improving population dispersal and growth. Tourism is viewed as important because of its potential to generate income and influence community development. Governing organizations however, must play a greater role in collaborating and providing support to the protected areas if these objectives are to be met to make tourism in Izabal sustainable.

\subsection{Contributions and Further Research}

On a regional scale, the study contributes to site-specific literature development within a tourism context. It develops an understanding of tourism to protected areas and community development in Lake Izabal, a location where research was lacking. The research also provides an updated perspective on the sustainable developmental progress of Rio Dulce from the earlier work conducted in the region by Perlack et al. (2001). It contributes to an understanding of the perceived roles of park planning and management institution and how their roles affect efforts to plan and manage sustainable tourism. Furthermore, research that addresses a broad range of impact types, such as social, economic, and environmental impacts, can potentially provide a substantial contribution to tourism planning and management (Geneletti \& Dawa, 2009). The recommendations provided in the study for management and planning institutions, ranging from local (e.g., FUNDAECO) to national (e.g., INGUAT) scales, address various impacts

The study examined sustainable tourism development for the protected areas of Cerro San Gil, Rio Dulce National Park, and Chocon Machacas, located in the Lake Izabal-Rio Dulce region. Research can be directed from a regional scale to a smaller geographical, local area by 
examining a specific protected area in this region. The research in this study can be utilized as a starting point to develop literature on a protected area in greater detail. Moreover, the perspectives of different groups may also be more closely examined. In this study, the views of the planning and managing organizations were determined through representatives of these organizations, and hence a focus was placed on this group. Determining community perspectives within a protected area can aid in producing an enhanced understanding of the roles of communities in tourism development and the relationships they may have with the park and planning organizations and their representatives.

In terms of biodiversity, the study contributed to an understanding of conservation work already occurring in the protected areas. In the region, threatened species of manatees and the goldenmantled howler monkey were used as indicators for an environmental impact assessment due to a lack of catalogued flora and fauna data (Perlack et al., 2001). However, bird and amphibian species were noted as indicators for the health of the forest and thus are being worked with to catalogue and maintain records of such species. Developing indicators is also important because it is a more concrete method to define sustainability. Further studies can examine the protected areas as a corridor that allows the movement of species throughout the region as this has yet to be formally evaluated in terms of how effective this corridor is (CONAP \& FONACON, 2004).

The research also aims to increase awareness of the importance of strengthening organizational collaboration in order to elevate the level of protection and sustainable tourism development in the protected areas in Izabal. Since the protected areas here, and especially in Rio Dulce National Park as mentioned in the interviews, are the prime attractions for tourism in the region, then all 
levels of government, as well as the private sector, should work together to ensure that conservation goals are being met, tourist numbers are increased in a responsible manner, and the protected areas are given the necessary financial and managerial support needed to maintain operation. Included in this is the need to develop policy that allows tourism governing bodies to regulate tourism through the regulation of tour operators, enforcement, and visitor management.

An important initiative is to include business owners, particularly hoteliers, retailers and restaurant owners, in follow-up research in Izabal. They were not included in this study because the focus fell on tourism planning and management from the perspective of the organizations responsible for the protected areas and the perceived relationships they have with tourists and communities. Retailers, for example, serve as intermediaries between tourist consumers and artisans in the marketing of craft products (Moreno \& Littrell, 2001). Moreno and Littrell (2001) used the town of Antigua, Guatemala as the field site for their study and, as such, opportunities exist in Izabal to examine the connections between tourists and business owners. Moreover, research should be directed at evaluating the networks of local entrepreneurs because of their role in supporting tourism development in the long term, which in turn would support new businesses (Wallace \& Diamente, 2005). The towns described here, particularly Las Fronteras and Puerto Barrios, can be used as starting points to conduct such studies.

\subsection{Conclusion}

The results of this study show that, if tourism in Izabal is to be sustainable, there is an urgency to implement frameworks to manage visitors, collect fees, and collaborate effectively with the planning and management organizations at local, regional, and national scales. Amongst the

protected areas examine in this study, Cerro San Gil appears to be managed the most effectively 
in comparison to Rio Dulce National Park and Chocon Machacas. This is due to Cerro San Gil having a few established visitor monitor points, a fee structure, and a greater level of community participation than that of RDNP and Chocon Machacas. Even so, problems persist with a lack of governmental support. At the regional level, issues of visitor management, community development, and institutional development continue to hinder sustainable tourism development.

Efforts to develop and implement initiatives for sustainable tourism in Izabal are important in marketing Guatemala as a competitive destination within the Central American market and international market. In addition, Izabal contains an abundant amount of natural resources, including biodiversity, and its marketing as Caribbean Guatemala reflects the potential for this area to grow as a tourist destination. In doing so, social, economic, and environmental integrity must be maintained by planning sustainable tourism and effectively managing it. This requires a considerable joint effort from the stakeholders involved to develop policies that allow the enforcement of rules and laws, administration of tour operator networks, and implementation of environmental conservation objectives. Currently, statistics related to visitation for each of the protected areas are not available. Gathering and maintaining such information is important for resource allocation decisions to meet the aforementioned objectives and efforts.

The blame exerted on communities as the sole cause of environmental pressure results in an alienation of the residents within the protected areas. They are put in that position due to a lack of employment and alternative methods of generating income, forcing them to rely on the extraction of natural resources. In order to develop sustainable tourism, community development must be an integral component of tourism planning and management because they have an 
influence on the extraction of natural resources and hence an influence on environmental conservation efforts. Also, because the natural environment acts as a driver of tourism to the protected areas, conserving biodiversity and ecosystems is in the best interest of stakeholders seeking alterative income generating opportunities to achieve a balance of social, economic, and environmental aspects of sustainable tourism development in the Lake Izabal region. 


\section{Appendices}

\section{Appendix A: Consent form for park planners and managers (English and Spanish)}

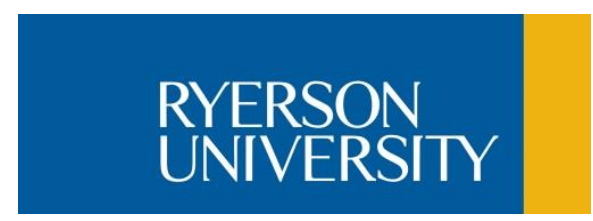

CONSENT TO PARTICIPATE IN RESEARCH

\section{Sustainable Tourism Development in Guatemala as a Driver of Increased Environmental Protection}

You are being invited to participate in a research study. Please read this Consent Form so that you understand what your participation will involve. Before you consent to participate, please ask any questions necessary to be sure you understand what your participation will involve.

\section{INVESTIGATORS}

This research study is being conducted by Cesar Rene Gonzalez, from the Environmental Applied Science and Management Program at Ryerson University. The results from the study will contribute to the development of a thesis to be submitted as part of the program's requirement to obtain a Master's degree. The supervisor of this research study is Dr. Kelly MacKay, a full professor and director of the Tourism and Hospitality Research Institute at the Ted Rogers School of Management at Ryerson University.

If you have any questions or concerns about the research, please feel free to contact me, Cesar Rene Gonzalez, at c36gonza@ryerson.ca, or Dr. Kelly MacKay at k7mackay@ryerson.ca.

\section{PURPOSE OF THE STUDY}

The purpose of this study is to explore the extent to which parks and protected areas in the vicinity of Lake Izabal, Guatemala are being managed for the purposes of tourism and how environmental, social, economic, and cultural impacts are taken into account. The objective is to understand the various relationships that exist between tourism and the environment, including how it affects social, economic and cultural aspects. A second objective is to evaluate the effectiveness of geographic information systems to produce relevant information that may help guide sustainable tourism development. Finally, a third objective will be to apply this system to identify the potential expansion of environmental protection.

\section{DESCRIPTION OF THE STUDY AND YOUR PARTICIPATION}

If you volunteer to participate in this study, you will be asked to do the following things:

- Participate in an hour-long interview in order to determine ways in which the park/protected area is managed and planned for the purposes of sustainable tourism development and environmental protection.

- You will be audio recorded and notes will be taken by me. 
The location of the interviews will be conducted on-site, at the park or protected area, or in a private location of your choosing so long as it is within Izabal. The questions to be asked will pertain to sustainable tourism development, ways in which the environment, society, and the economy are taken into account, how these aspects are valued and weighed when making decisions, how important tourism is to the park or protected area, the geography of the park or area in question, and ways improvements can be made in tourism development and planning. Questions will range from simple yes and no to longer, more open-ended questions. Data from the interview will be collected, coded and inputted into a geographic information system based on thematic results pertaining to environmental, social, economic and cultural aspects. Some sample questions are provided:

- What do you think of Guatemala's current parks and management practices with respect to sustainable tourism development?

- What are some of the greatest environmental pressures that this park experiences?

- What are some of the social and economic impacts tourism (to this park) has had on the local communities?

Interview results will be available to you for review after they have been transcribed. Audio recordings will be destroyed after the interview has been transcribed. Research findings will also be available to you upon request. They will be made available electronically via email and upon the completion of the initial thesis draft.

\section{POTENTIAL RISKS AND DISCOMFORTS}

The potential risks for participating in this study are very low and are described below.

Potential risks may include discomfort in discussing current management practices that may be unsustainable or bring up uncomfortable past events, presenting some social and economic risk. As such, questions pertaining to past management practices will be kept to a minimum. Discussions on budget expenditures and personal values will be avoided and not queried upon.

The risks are minimal as the main goal of the study is to aid the development of sustainable tourism and environmental protection through the improvement of management practices or decision making processes, not the identification and analysis of unsustainable practices. The risk is reasonable given the potential benefits of the study to the development of sustainable tourism in Guatemala, the development of decision making frameworks through the use of geographic information systems, and the potential increase of environmental protection.

You are free to skip questions, stop participating at any time or take a break if needed, for any reason.

\section{POTENTIAL BENEFITS TO PARTICIPANTS AND/OR TO SOCIETY}

The potential benefits you may expect from the research are gaining a greater understanding of potential improvements to sustainable tourism practices and the ability of geographic information systems to facilitate decision making procedures that allow the environment and tourism to be managed effectively.

Opportunities exist in Guatemala and in the use of geographic information systems for the exploration, analysis and evaluation of sustainable tourism development that may benefit the region specifically in identifying areas that require attention with respect to tourism development and environmental protection. Also, research that addresses a broad range of impacts for poorly studied areas in tourism can provide a significant contribution to the development of tourism planning and management.

I cannot guarantee, however, that you will receive any benefits from participating in this study. 


\title{
PAYMENT FOR PARTICIPATION
}

\author{
You will not be paid to participate in this study.
}

\section{CONFIDENTIALITY}

You will not be identified by name, specific job title/position, age, gender or physical characteristics but rather under the general term of planner or manager in the thesis. Responses will be coded based on cultural, economic, environmental and social themes and then integrated into a geographic information system, thereby removing information that may be used in identifying you. Access to information will be made available to you upon request after analysis has been conducted and the initial thesis draft has been completed. The data will be secured under passwords, encrypted and backed up on an external drive, also to be secured in this manner. The data will be retained 6 months after the final thesis is completed, after which point it will be destroyed. Transcript recording of interviews and coded responses may be released to the supervisor of this thesis, namely Dr. Kelly MacKay, in order to provide guidance and information on the completion of the thesis.

You will be allowed to review your transcribed interview to check for accuracy and to remove any information that you may deem too sensitive or risky. The audio recording will be stored in encrypted files and I, Cesar Rene Gonzalez and my supervisor, Dr. Kelly MacKay, will have access to the raw and transcribed recordings. The recordings will only be used towards the completion of the thesis and will be destroyed immediately after they have been transcribed.

\section{VOLUNTARY PARTICIPATION AND WITHDRAWAL}

Participation in this study is voluntary. You can choose whether to be in this study or not. If you volunteer to be in this study, you may withdraw at any time without consequences of any kind. If you choose to withdraw from this study you may also choose to withdraw your data from the study. You may also choose not to answer any question(s) and still remain in the study. Your choice of whether or not to participate will not influence your future relations with Ryerson University.

\section{QUESTIONS ABOUT THE STUDY}

If you have any questions about the research now, please ask. If you have questions later about the research, you may contact:

Cesar Rene Gonzalez: c36gonza@ryerson.ca

Dr. Kelly MacKay: k7mackay@ryerson.ca

This study has been reviewed by the Ryerson University Research Ethics Board. If you have questions regarding your rights as a research participant in this study, please contact:

\author{
Toni Fletcher, Research Ethics Coordinator \\ Research Ethics Board \\ Office of the Vice President, Research and Innovation \\ Ryerson University \\ 350 Victoria Street \\ Toronto, Ontario M5B 2K3 \\ 416-979-5042 or toni.fletcher@ryerson.ca
}




\section{SIGNATURE OF RESEARCH PARTICIPANT}

Your signature below indicates that you have read the information in this agreement and have had a chance to ask any questions you have about the study Sustainable Tourism Development in Guatemala as a Driver of Increased Environmental Protection as described herein. Your questions have been answered to your satisfaction, and you agree to participate in this study. You have been given a copy of this form.

Name of Participant (please print)

Signature of Participant

Date

Your signature below acknowledges that you have read and understood that you will be audiorecorded for the purposes of this study. 


\title{
RYERSON
}

UNIVERSITY

\author{
CONSENTIMIENTO PARA PARTICIPAR EN LA INVESTIGACIÓN
}

\section{Desarrollo Sostenible del Turismo en Guatemala Como un Conductor de Mayor Protección del Medio Ambiente}

\begin{abstract}
Usted esta invitado a participar en un estudio. Por favor, lea este formulario de consentimiento para que pueda entender lo que su participación implica. Antes de su consentimiento para participar, por favor hacer cualquier pregunta necesarias para asegurarse de que entiende lo que su participación implica.
\end{abstract}

\section{INVESTIGADORES}

Este estudio esta está siendo realizado por Cesar Rene Gonzalez, de la Programa de Gestión de la Ciencia Aplicada y Ambiental en la Universidad de Ryerson. Los resultados de este estudio contribuirán al desarrollo de una tesis que se presentará como parte de los requisitos del programa para obtener un título de maestría. La supervisora de este estudio es la Dr. Kelly MacKay, profesor titular y director del Instituto de Investigación de Turismo y Hospitalidad en el Ted Rogers Escuela de Gestión de la Universidad de Ryerson.

Si usted tiene alguna pregunta o preocupación acerca de la investigación, no dude en ponerse en contacto conmigo, Cesar Rene Gonzalez, c36gonza@ryerson.ca, o con Dr. Kelly MacKay, k7mackay@ryerson.ca.

\section{PROPÓSITO DEL ESTUDIO}

El propósito de este estudio es explorar el grado en que los parques y áreas protegidas alrededores del Lago Izabal, Guatemala están siendo manejadas por el proposito de turismo y cómo el medio ambiente, los impactos sociales, económicos y culturales se tienen en cuenta. El objetivo es entender las diferentes relaciones que existen entre el turismo y el medio ambiente. Un segundo objetivo es evaluar la efectividad de los sistemas de información geográfica para producir información pertinente que pueda ayudar al desarrollo del turismo sostenible. Por último, un tercer objetivo será aplicar este sistema para identificar el potencial de expansión de la protección del medio ambiente.

\section{DESCRIPCIÓN DEL ESTUDIO Y SU PARTICIPACIÓN}

\section{Si usted es voluntario para participar en este estudio, se le pedirá hacer las siguientes cosas:}

- Participar en una entrevista de una hora para determinar la manera en que el parque/ área protegida esta gestionado y planificado para el desarrollo del turismo sostenible y la protección del medio ambiente.

- Usted será grabado con grabador de audio y notas serán escritos por mí.

El lugar de las entrevistas será conducida en el parque o área protegida, o en un lugar privado de su elección, pero que sea dentro de Izabal. Las preguntas que se le preguntara se pertenecen al desarrollo sostenible del turismo, las formas en que el medio ambiente, la sociedad y la economía se tienen en cuenta, cómo se valoran estos aspectos y se pesan en la toma de decisiones, cómo el turismo es 
importante para el parque o área protegida, la geografía del parque o área protegida, y maneras para mejorar el desarrollo turístico y la planificación. Las preguntas van desde simples sí o no a las preguntas más largas y abiertas. Los datos de la entrevista serán recogidos, codificados y entrada en un sistema de información geográfica basado en resultados temáticas que tienen relación con los aspectos ambientales, sociales, económicos y culturales. Algunas ejemplos de preguntas:

- ¿Qué piensa usted de los parques actuales de Guatemala y prácticas de gestión con respecto al desarrollo del turismo sustentable?

- ¿Cuáles son algunas de las mayores presiones ambientales que este parquet experiencia?

- ¿Cuáles son algunos de los impactos del turismo que este parque ha tenido sobre las comunidades locales?

Resultados de las entrevistas estarán disponibles para su revisión después de que se han sido transcritos. Las grabaciones de audio seran destruido después de que la entrevista ha sido transcrita. Resultados de la investigación estarán disponibles a su solicitud por medio de correo electrónico y sobre la finalización del proyecto de tesis inicial.

\section{RIESGOS POSIBLES Y INCOMODIDADES}

Los riesgos potenciales para participar en este estudio son muy bajos y se describen a continuación.

Los riesgos potenciales pueden incluir incomodidades en la discusión de las prácticas actuales de gestión que pueden ser insostenibles o traer eventos pasados incómodos presentando un riesgo social y económico. Por lo tanto, las preguntas a las prácticas de gestión pasadas se mantendrán al mínimo. Las discusiones sobre los gastos del presupuesto y los valores personales serán evitados y no seran preguntado.

Los riesgos son mínimos, ya que el objetivo principal del estudio es ayudar al desarrollo del turismo sostenible y la protección del medio ambiente a través de la mejora de las prácticas de gestión o procesos y no en la identificación y análisis de las prácticas insostenibles. El riesgo es razonable teniendo en cuenta los posibles beneficios del estudio para el desarrollo del turismo sostenible en Guatemala, el desarrollo del uso de sistemas de información geográfica y el potencial aumento de la protección del medio ambiente.

Usted es libre de omitir las preguntas, dejar de participar en cualquier momento o tomar un descanso si es necesario, por cualquier razón.

\section{POSIBLES BENEFICIOS PARA LOS PARTICIPANTES Y / O CON LA SOCIEDAD}

Los beneficios potenciales que se pueden esperar de la investigación es una mayor comprensión de las posibles mejoras de las prácticas de turismo sostenible y la capacidad de los sistemas de información geográfica para facilitar la toma de decisions que permitan el medio ambiente y el turismo para ser tratados eficazmente.

Existen oportunidades en Guatemala y en el uso de sistemas de información geográfica para la exploración, el análisis y la evaluación del desarrollo del turismo sostenible, que puede beneficiar a la región específica en la identificación de áreas que necesita atención en relación con el desarrollo del turismo y la protección del medio ambiente. Además, la investigación que se ocupa de una amplia gama de impactos para áreas poco estudiadas en el turismo puede contribuir significativamente al desarrollo de la planificación y gestión del turismo.

No puedo garantizar, sin embargo, que va a recibir los beneficios de participar en este estudio. 


\title{
PAGO DE PARTICIPACIÓN
}

No se le paga para participar en este studio.

\section{CONFIDENCIALIDAD}

Usted no será identificado por su nombre, trabajo específico, título / cargo, la edad, el sexo o las características físicas, sino más bajo el término general de planificador o gestor de la tesis. Las respuestas seran codificado en base a temas culturales, económicos, ambientales y sociales y luego seran integrado en un sistema de información geográfica, eliminando información que puede ser utilizada en la identificación de usted. Acceso a la información estará disponible si lo solicita después del análisis se ha llevado a cabo y el proyecto de tesis inicial se ha completado. Los datos serán segurados con contraseñas, encriptado y tambien en una copia de disco duro externo, que también sera asegurado de esta manera. Los datos serán retenidos 6 meses después de que se completó la tesis final, despues de que tiempo sera destruido. Transcripción de la grabación de las entrevistas y las respuestas codificadas puede ser liberado al supervisor de la tesis, la Dr. Kelly MacKay, a fin de proporcionar orientación e información sobre la realización de la tesis.

Usted sera permitido revisar la entrevista transcrita para comprobar su exactitud y eliminar cualquier información que usted considere demasiado sensibles o riesgoso. La grabación de audio se almacena en archivos encriptados y yo, Cesar Rene Gonzalez y mi supervisora, Dr. Kelly MacKay, tendrán acceso a las grabaciones y transcritas. Las grabaciones sólo seran utilizado para la realización de la tesis y se destruirán inmediatamente después de haber sido transcritas.

\section{PARTICIPACIÓN VOLUNTARIA Y RETIRO}

La participación en este estudio es voluntaria. Usted puede elegir si desea estar en este estudio o no. Si usted es voluntario para participar en este estudio, puede retirarse en cualquier momento sin ningún tipo de consecuencias. Si decide retirarse de este estudio también puede optar por retirar los datos del estudio. También puede optar por no contestar a cualquier pregunta(s) y aún permanecer en el estudio. La elección de si desea o no participar no afectará sus futuras relaciones con la Universidad de Ryerson.

\section{PREGUNTAS SOBRE EL ESTUDIO}

Si usted tiene alguna pregunta acerca de la investigación, por favor pregunte. Si tiene preguntas después de la investigación, puede comunicarse con:

Cesar Rene Gonzalez: c36gonza@ryerson.ca

Dr. Kelly MacKay: k7mackay@ryerson.ca

Este estudio ha sido revisado por la Junta de Ética de Investigación de la Universidad Ryerson. Si usted tiene preguntas sobre sus derechos como participante de la investigación en este estudio, por favor póngase en contacto con:

\author{
Toni Fletcher, Research Ethics Coordinator \\ Research Ethics Board \\ Office of the Vice President, Research and Innovation \\ Ryerson University \\ 350 Victoria Street \\ Toronto, Ontario M5B 2K3 \\ 416-979-5042 or toni.fletcher@ryerson.ca
}




\section{FIRMA DE INVESTIGACIÓN PARTICIPANTES}

Su firma indica que usted ha leído la información en este acuerdo y ha tenido la oportunidad de formular las preguntas que tenga sobre el estudio de desarrollo del turismo sostenible en Guatemala como un conductor de mayor protección del medio ambiente, como se describe en este documento. Sus preguntas han sido contestadas a su satisfacción, y usted acepta participar en este estudio. Se le ha dado una copia de este formulario.

Nombre del participante (en letra de imprenta)

Firma del participante

Su firma abajo indica que ha leído y entendido que va a ser grabado en audio para los fines de este estudio. 


\section{Appendix B: Interview guide for park planners and managers}

\section{Interview Questions for Park Managers/Planners in English:}

These are some of the main topics to be discussed upon. Any revisions to be made may involve some modification of the questions.

1. What do you think of Guatemala's current parks and management practices with respect to sustainable tourism development?

2. Are they (the Guatemalan government) meeting those goals?

3. What are some of the greatest environmental pressures that this park experiences?

4. What are some of the social and economic impacts tourism (to this park) has had on the local communities?

5. Can you provide me with the geographical characteristics of the park? (Boundaries, area, total perimeter, endangered species in the park, number of tourists per month/year)

6. What is your role in environmental management?

7. What role does this park/protected area play in environmental protection?

8. How important is tourism to this area?

9. Is there is specific framework used for decision making?

10. Are spatial decision-making tools used at all in making decisions? If no, would such a tool be useful for your purposes? What challenges have been associated with obtaining such tools or software?

11. If yes, what challenges have you (or the park employees in general) faced with respect to integrating data, or working with others in making decisions using spatially-based tools (GIS)?

12. Is there a challenge/issue of data collection and data sharing?

13. How do past practices differ from current practices with respect to tourism growth and sustainable park planning and management?

14. What species, flora and fauna, are currently protected? Which require more protection? How can this be accomplished?

15. What criteria do you use to select sites that require attention (i.e. for conservation purposes or to develop touristic services)?

\section{Preguntas en Español}

1. ¿Qué piensa usted de los parques actuales de Guatemala y prácticas de gestión con respecto al desarrollo del turismo sostenible?

2. Son ellos (el gobierno Guatemalteco) cumpliendo esas metas?

3. ¿Cuáles son algunas de las mayores presiones ambientales que experimenta este parque?

4. ¿Cuáles son algunos de los impactos social y económico (a este parque) que tourismo ha tenido sobre las comunidades locales?

5. ¿Me puede dar las características geográficas del parque? (Límites, área, perímetro total, las especies en peligro de extinción en el parque, el número de turistas al mes / año) 
6. ¿Cuál es su rol en la gestión del medio ambiente?

7. ¿Qué rol juega este parque / área protegida en la protección del medio ambiente?

8. ¿Qué tan importante es el turismo a esta zona?

9. ¿Existe un marco específico utilizado para la toma de decisiones?

10. ¿Se usa herramientas de toma de decisiones espaciales en absoluto en la toma de decisiones? Si no, sería una herramienta sea útil para sus propósitos? ¿A qué retos se han asociado con la obtención de este tipo de herramientas o software?

11. ¿En caso afirmativo, qué retos usted (o los empleados del parque en general) se enfrentan con respecto a la integración de datos, o trabajar con otras personas en la toma de decisiones utilizando herramientas basados en el espacio?

12. ¿Hay un problema / tema de la recolección de datos y el intercambio de datos?

13. ¿De qué manera las prácticas anteriores difieren de las prácticas actuales en relación con el crecimiento del turismo y la planificación y gestión del parque sostenible?

14. ¿Qué especies, flora y fauna, están protegidos en la actualidad? ¿Qué requieren más protección? ¿Cómo se puede lograr esto?

15. ¿Qué criterios utiliza para seleccionar los sitios que requieren atención (es decir, con fines de conservación o el desarrollo de servicios turísticos)? 


\section{Appendix C: Consent form for tourists (English and Spanish)}

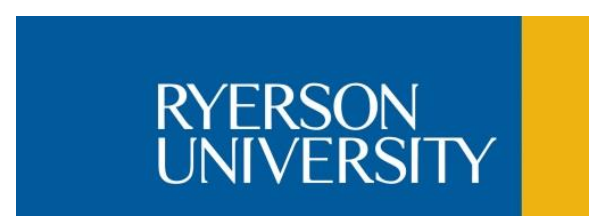

CONSENT TO PARTICIPATE IN RESEARCH

\section{Sustainable Tourism Development in Guatemala as a Driver of Increased Environmental Protection}

You are being invited to participate in a research study. Please read this Consent Form so that you understand what your participation will involve. Before you consent to participate, please ask any questions necessary to be sure you understand what your participation will involve.

\section{INVESTIGATORS}

This research study is being conducted by Cesar Rene Gonzalez, from the Environmental Applied Science and Management Program at Ryerson University. The results from the study will contribute to the development of a thesis to be submitted as part of the program's requirement to obtain a Master's degree. The supervisor of this research study is Dr. Kelly MacKay, a full professor and director of the Tourism and Hospitality Research Institute at the Ted Rogers School of Management at Ryerson University.

If you have any questions or concerns about the research, please feel free to contact me, Cesar Rene Gonzalez, at c36gonza@ryerson.ca, or Dr. Kelly MacKay at k7mackay@ryerson.ca.

\section{PURPOSE OF THE STUDY}

The purpose of this study is to explore the extent to which parks and protected areas in the vicinity of Lake Izabal, Guatemala are being managed for the purposes of tourism and how environmental, social, economic, and cultural impacts are taken into account. The objective is to understand the various relationships that exist between tourism and the environment, including how it affects social, economic and cultural aspects. A second objective is to evaluate the effectiveness of geographic information systems to produce relevant information that may help guide sustainable tourism development. Finally, a third objective will be to apply this system to identify the potential expansion of environmental protection.

\section{DESCRIPTION OF THE STUDY AND YOUR PARTICIPATION}

If you volunteer to participate in this study, you will be asked to do the following things:

- Participate in a short, 10-minute interview in order to determine tourist preferences relating to what attracts you to a region or area, sustainable tourism development and environmental protection.

- Notes of your response(s) will be taken by me.

The location of the interviews will be conducted on-site or in a private location of your choosing so long as it is within the park or protected area under study. The questions to be asked will pertain to your purpose 
of travel and your views on the role protected areas play in the development of sustainable tourism development. Questions will range from simple yes and no to longer, more open-ended questions. Data from the interview will be collected, coded and inputted into a geographic information system based on thematic results pertaining to environmental, social, economic and cultural aspects. Some sample questions are provided:

- What is your main purpose of travel to Izabal?

- What would you consider the most memorable feature of the park?

Interview results will be available to you for review after they have been coded. Research findings will also be available to you upon request. They will be made available electronically via email and upon the completion of the initial thesis draft should you request it.

\section{POTENTIAL RISKS AND DISCOMFORTS}

The potential risks for participating in this study are very low and are described below.

Potential risks may include discomfort in discussing topics such as purpose of travel, as it may reveal travel that may not be socially or environmentally responsible and therefore presents some risk.

The risks are minimal because the responses will only be based on thematic results and grouped with similar responses, with the goal of identifying tourist preferences that will serve as a complementary to information gained from other interviews. As such, you will not be identified as the responses will be coded based on thematic aspects relating to purpose of travel. The risk is reasonable given the potential benefits of the study to the development of sustainable tourism in Guatemala, the development of decision making frameworks through the use of geographic information systems, and the potential increase of environmental protection.

You are free to skip questions, stop participating at any time or take a break if needed.

\section{POTENTIAL BENEFITS TO PARTICIPANTS AND/OR TO SOCIETY}

The potential benefits you may expect from the research are gaining a greater understanding of potential improvements to sustainable tourism practices and working towards a goal to ensure that your needs are met by this park/protected area in the future should you choose to return.

Opportunities exist in Guatemala and in the use of geographic information systems for the exploration, analysis and evaluation of sustainable tourism development that may benefit the region specifically in identifying areas that require attention with respect to tourism development and environmental protection. Also, research that addresses a broad range of impact types for poorly studied areas in tourism can provide a significant contribution to the development of tourism planning and management.

I cannot guarantee, however, that you will receive any benefits from participating in this study.

\section{PAYMENT FOR PARTICIPATION}

\section{You will not be paid to participate in this study.}




\title{
CONFIDENTIALITY
}

You will not be identified by name, job title/position, age, gender or physical characteristics but rather as a tourist in the thesis. Responses will be coded based on cultural, economic, environmental and social themes and then integrated into a geographic information system, thereby removing information that may be used in identifying you. Access to information will be made available to you upon request after analysis has been conducted and the initial thesis draft has been completed. The data will be secured under passwords, encrypted and backed up on an external drive, also to be secured in this manner. The data will be retained 6 months after the final thesis is completed, after which point it will be destroyed. Coded responses may be released to the supervisor of this thesis, namely Dr. Kelly MacKay, in order to provide guidance and information on the completion of the thesis.

You will be allowed to review your coded interview to check for accuracy and to remove any information that you may deem too sensitive or risky. The coded interview data will only be used towards the completion of the thesis.

\section{VOLUNTARY PARTICIPATION AND WITHDRAWAL}

Participation in this study is voluntary. You can choose whether to be in this study or not. If you volunteer to be in this study, you may withdraw at any time without consequences of any kind. If you choose to withdraw from this study you may also choose to withdraw your data from the study. You may also choose not to answer any question(s) and still remain in the study. Your choice of whether or not to participate will not influence your future relations with Ryerson University.

\section{QUESTIONS ABOUT THE STUDY}

If you have any questions about the research now, please ask. If you have questions later about the research, you may contact:

Cesar Rene Gonzalez: c36gonza@ryerson.ca

Dr. Kelly MacKay: k7mackay@ryerson.ca

This study has been reviewed by the Ryerson University Research Ethics Board. If you have questions regarding your rights as a research participant in this study, please contact:

\author{
Toni Fletcher, Research Ethics Coordinator \\ Research Ethics Board \\ Office of the Vice President, Research and Innovation \\ Ryerson University \\ 350 Victoria Street \\ Toronto, Ontario M5B 2K3 \\ 416-979-5042 or toni.fletcher@ryerson.ca
}




\section{SIGNATURE OF RESEARCH PARTICIPANT}

Your signature below indicates that you have read the information in this agreement and have had a chance to ask any questions you have about the study Sustainable Tourism Development in Guatemala as a Driver of Increased Environmental Protection as described herein. Your questions have been answered to your satisfaction, and you agree to participate in this study. You have been given a copy of this form.

Name of Participant (please print)

Signature of Participant

Date 


\title{
RYERSON
}

UNIVERSITY

\author{
CONSENTIMIENTO PARA PARTICIPAR EN LA INVESTIGACIÓN
}

\section{Desarrollo Sostenible del Turismo en Guatemala Como un Conductor de Mayor Protección del Medio Ambiente}

\begin{abstract}
Usted esta invitado a participar en un estudio. Por favor, lea este formulario de consentimiento para que pueda entender lo que su participación implica. Antes de su consentimiento para participar, por favor hacer cualquier pregunta necesarias para asegurarse de que entiende lo que su participación implica.
\end{abstract}

\section{INVESTIGADORES}

Este estudio esta está siendo realizado por Cesar Rene Gonzalez, de la Programa de Gestión de la Ciencia Aplicada y Ambiental en la Universidad de Ryerson. Los resultados de este estudio contribuirán al desarrollo de una tesis que se presentará como parte de los requisitos del programa para obtener un título de maestría. La supervisora de este estudio es la Dr. Kelly MacKay, profesor titular y director del Instituto de Investigación de Turismo y Hospitalidad en el Ted Rogers Escuela de Gestión de la Universidad de Ryerson.

Si usted tiene alguna pregunta o preocupación acerca de la investigación, no dude en ponerse en contacto conmigo, Cesar Rene Gonzalez, c36gonza@ryerson.ca, o con Dr. Kelly MacKay, k7mackay@ryerson.ca.

\section{PROPÓSITO DEL ESTUDIO}

El propósito de este estudio es explorar el grado en que los parques y áreas protegidas alrededores del Lago Izabal, Guatemala están siendo manejadas por el proposito de turismo y cómo el medio ambiente, los impactos sociales, económicos y culturales se tienen en cuenta. El objetivo es entender las diferentes relaciones que existen entre el turismo y el medio ambiente. Un segundo objetivo es evaluar la efectividad de los sistemas de información geográfica para producir información pertinente que pueda ayudar al desarrollo del turismo sostenible. Por último, un tercer objetivo será aplicar este sistema para identificar el potencial de expansión de la protección del medio ambiente.

\section{DESCRIPCIÓN DEL ESTUDIO Y SU PARTICIPACIÓN}

\section{Si usted es voluntario para participar en este estudio, se le pedirá hacer las siguientes cosas:}

- Participar en una entrevista corta, de 10 minutos con el fin de determinar las preferencias turísticas relacionadas con lo que atrae a una tourista a la región o zona, el desarrollo del turismo sostenible y la protección del medio ambiente.

- Notas serán escritos por mí.

La localización de la entrevista será conducida en el lugar o en un lugar privado de su elección, siempre y cuando esté dentro del parque o área protegida en estudio. Las preguntas que se le pregunte corresponderán al motivo del viaje y sus opiniones sobre la función de áreas protegidas en el desarrollo del turismo sostenible. Las preguntas van desde simples sí o no a las preguntas más largas y abiertas. 
Los datos de la entrevista serán recogidos, codificados y entrada en un sistema de información geográfica basado en resultados temáticas que tienen relación con los aspectos ambientales, sociales, económicos y culturales. Algunas ejemplos de preguntas:

- ¿Cuál es su propósito principal de viaje a Izabal?

- ¿Cuál considera usted la característica más memorable del parque?

Resultados de las entrevistas estarán disponibles para su revisión después de que se han sido codificados. Resultados de la investigación estarán disponibles a su solicitud por medio de correo electrónico y sobre la finalización del proyecto de tesis inicial.

\section{RIESGOS POSIBLES Y INCOMODIDADES}

Los riesgos potenciales para participar en este estudio son muy bajos y se describen a continuación.

Los riesgos potenciales pueden incluir incomodidades en la discusión de temas como el motivo del viaje, ya que puede revelar viajes que no pueden ser socialmente o ambientalmente responsable y por lo tanto presenta un riesgo.

Los riesgos son mínimos porque las respuestas sólo se basan en los resultados temáticos y se agrupan con respuestas similares, con el objetivo de identificar las preferencias de los turistas que servirán de complemento a la información obtenida de otras entrevistas. El riesgo es razonable teniendo en cuenta los posibles beneficios del estudio para el desarrollo del turismo sostenible en Guatemala, el desarrollo del uso de sistemas de información geográfica y el potencial aumento de la protección del medio ambiente.

Usted es libre de omitir las preguntas, dejar de participar en cualquier momento o tomar un descanso si es necesario, por cualquier razón.

\section{POSIBLES BENEFICIOS PARA LOS PARTICIPANTES Y / O CON LA SOCIEDAD}

Los beneficios potenciales que se pueden esperar de la investigación es una mayor comprensión de las posibles mejoras de las prácticas de turismo sostenible y trabajando hacia la meta de asegurar que sus necesidades sean satisfechas por este parque / área protegida en el futuro si decide volver

Existen oportunidades en Guatemala y en el uso de sistemas de información geográfica para la exploración, el análisis y la evaluación del desarrollo del turismo sostenible, que puede beneficiar a la región específica en la identificación de áreas que necesita atención en relación con el desarrollo del turismo y la protección del medio ambiente. Además, la investigación que se ocupa de una amplia gama de impactos para áreas poco estudiadas en el turismo puede contribuir significativamente al desarrollo de la planificación y gestión del turismo.

\section{No puedo garantizar, sin embargo, que va a recibir los beneficios de participar en este estudio.}

\section{PAGO DE PARTICIPACIÓN}

No se le paga para participar en este studio. 


\title{
CONFIDENCIALIDAD
}

Usted no será identificado por su nombre, trabajo, título / cargo, la edad, el sexo o las características físicas, sino más bajo el término general de tourista en la tesis. Las respuestas seran codificado en base a temas culturales, económicos, ambientales y sociales y luego seran integrado en un sistema de información geográfica, eliminando información que puede ser utilizada en la identificación de usted. Acceso a la información estará disponible si lo solicita después del análisis se ha llevado a cabo y el proyecto de tesis inicial se ha completado. Los datos serán segurados con contraseñas, encriptado y tambien en una copia de disco duro externo, que también sera asegurado de esta manera. Los datos serán retenidos 6 meses después de que se completó la tesis final, despues de que tiempo sera destruido. Las respuestas codificadas puede ser liberado al supervisor de la tesis, la Dr. Kelly MacKay, a fin de proporcionar orientación e información sobre la realización de la tesis.

Usted sera permitido reviser las respuestas codificadas para comprobar su exactitud y eliminar cualquier información que usted considere demasiado sensibles o riesgoso. Las respuestas codificadas seran utilizado para la realización de la tesis y se destruirán inmediatamente después de haber sido transcritas.

\section{PARTICIPACIÓN VOLUNTARIA Y RETIRO}

La participación en este estudio es voluntaria. Usted puede elegir si desea estar en este estudio o no. Si usted es voluntario para participar en este estudio, puede retirarse en cualquier momento sin ningún tipo de consecuencias. Si decide retirarse de este estudio también puede optar por retirar los datos del estudio. También puede optar por no contestar a cualquier pregunta(s) y aún permanecer en el estudio. La elección de si desea o no participar no afectará sus futuras relaciones con la Universidad de Ryerson.

\section{PREGUNTAS SOBRE EL ESTUDIO}

Si usted tiene alguna pregunta acerca de la investigación, por favor pregunte. Si tiene preguntas después de la investigación, puede comunicarse con:

Cesar Rene Gonzalez: c36gonza@ryerson.ca

Dr. Kelly MacKay: k7mackay@ryerson.ca

Este estudio ha sido revisado por la Junta de Ética de Investigación de la Universidad Ryerson. Si usted tiene preguntas sobre sus derechos como participante de la investigación en este estudio, por favor póngase en contacto con:

\author{
Toni Fletcher, Research Ethics Coordinator \\ Research Ethics Board \\ Office of the Vice President, Research and Innovation \\ Ryerson University \\ 350 Victoria Street \\ Toronto, Ontario M5B 2K3 \\ 416-979-5042 or toni.fletcher@ryerson.ca
}




\section{FIRMA DE INVESTIGACIÓN PARTICIPANTES}

Su firma indica que usted ha leído la información en este acuerdo y ha tenido la oportunidad de formular las preguntas que tenga sobre el estudio de desarrollo del turismo sostenible en Guatemala como un conductor de mayor protección del medio ambiente, como se describe en este documento. Sus preguntas han sido contestadas a su satisfacción, y usted acepta participar en este estudio. Se le ha dado una copia de este formulario.

Nombre del participante (en letra de imprenta)

Firma del participante

Fecha 


\section{Appendix D: Questionnaire for tourists}

Since the interviews to be conducted will be unstructured, there will be a few guiding questions that will aid in maintaining a specific focus during the discussions. Moreover, they will be short in length

(approximately 5 minutes).

Screening questions for eligibility:

- What is your main purpose of travel to lzabal?

- From where are you originating?

Further questions if criteria met:

- How did you come to know of this park? Is this your first time here?

- Is it what you expected based on (insert answer to question 2)?

- Are there any specific cultural, environmental or economic aspects that attracted to you to this site? Can you tell me about them? (probes: specific animals, natural features, vendors, etc.)

- What would you consider the most memorable feature of the park?

- How long is/was your visit to the park?

- Based on your experience in the park, what can park managers/planners do to better enhance the park as a tourist attraction?

In Spanish:

Preguntas de la elegibilidad:

1. ¿Cuál es su propósito principal de viaje a Izabal?

2. ¿¿Desde donde está originando?

Otras preguntas si cumplen los criterios:

3. ¿Cómo llego a saber de este parque? ¿Es su primera vez aquí?

4. ¿Es lo que esperaba sobre la base de (inserte respuesta a la pregunta 2)?

5. ¿Existen aspectos culturales, ambientales o económicos específicos que atrajo a usted a este sitio? ¿Me puede decir acerca de ellos? (sondas: animales específicos, características naturales, proveedores, etc)

6. ¿Cuál considera usted la característica más memorable del parque?

7. ¿Por cuánto tiempo es/fue su visita al parque?

8. ¿Basado en su experiencia en el parque, qué pueden hacer los erentes/planificadores para mejorar más el parque como una atracción turística? 


\section{References}

Andrade, G. S., \& Rhodes, J. R. (2012). Protected areas and local communities: an inevitable partnership toward successful conservation strategies? Ecology and Society, 17(4), 1-16.

Arnstein, S. R. (1969). A ladder of citizen participation. Journal of the American Planning Association, 35(4), 216-224.

Aswani, S., \& Weiant, P. (2004). Scientific evaluation in women's participatory management: Monitoring marine invertebrate refugia in the Solomon Islands. Human Organization, 63(3), 301-319.

Badurek, C. A. (2009). Identifying barriers to GIS-based land management in Guatemala. Development in Practice, 19(2), 248-258.

Bahaire, T., \& Elliott-White, M. (1999). The application of Geographical Information Systems (GIS) in sustainable tourism planning: A review. Journal of Sustainable Tourism, 7(2), $159-174$.

Beeton, S. (2005). The case study in tourism research: A multi-method case study approach. In B. W. Ritchie, P. Burns, \& C. Palmer, Tourism research methods: Integrating theory with practice (pp. 37-48). London, UK: CABI Publishing.

Beneditti, L. S. (2013). Marine Protected Areas (MPAs) as a fisheries management tool for the Nassau Grouper (Epinephelus striatus) in Belize. Theses and dissertations: Ryerson University.

Berger, S. A. (1997). Environmentalism in Guatemala: When fish have ears. Latin American Research Review, 32(2), 99-116. 
Binimelis, R., Monterroso, I., \& Rodriguez-Labajos, B. (2007). A social analysis of the bioinvasions of Dreissena polymorpha in Spain and Hydrilla verticillata in Guatemala. Environmental Management, 40(4), 555-566.

Boers, B., \& Cottrell, S. (2007). Sustainable tourism infrastructure planning: A GIS-supported approach. Tourism Geographies, 9(1), 1-21.

Bonham, C. A., Sacayon, E., \& Tzi, E. (2008). Protecting imperiled “"paper parks'”: potential lessons from the Sierra Chinaja', Guatemala. Biodiversity and Conservation, 17(7), 15811593.

Borrini-Feyerabend, G., Kothari, A., \& Oviedo, G. (2004). Indigenous and local communities and protected areas: Towards equity and enhanced conservation. Gland, Switzerland and Cambridge, UK: IUCN.

Bryman, A., Teevan, J. J., \& Bell, E. (2009). Social research methods second Canadian edition. Toronto, Canada: Oxford University Press.

Buckley, R. (2002). Draft principles for tourism in protected areas. Journal of Ecotourism, 1(1), 75-80.

Buckley, R. (2012). Sustainable tourism: Research and reality. Annals of Tourism Research, $39(2), 528-546$.

Campagna, M. (2006). GIS for sustainable development. Boca Raton, FL: CRC Press.

CAMTUR. (n.d.). Acerca de CAMTUR. Retrieved November 29, 2013, from Camtur: Cámara de Turismo de Guatemala:

http://www.camtur.org/index.php?option=com_content\&view=article\&id=121\&Itemid=2 8 
Chhetri, P., \& Arrowsmith, C. (2008). GIS-based modelling of recreational potential of naturebased tourist destinations. Tourism Geographies, 10(2), 233-257.

Choi, H. C., \& Sirakaya, E. (2006). Sustainability indicators for managing community tourism. Tourism Management, 27(6), 1274-1289.

Collins-Kreiner, N., Malkinson, D., Labinger, Z., \& Shtainvarz, R. (2013). Are birders good for birds? Bird conservation through tourism management in the Hula Valley, Israel. Tourism Management, 38, 31-42.

CONAP. (2013). Listado de areas protegidas: Sistema Guatemalteco de areas protegidas. Departamento de Unidades de Conservación. Guatemala City: CONAP.

CONAP. (n.d.). Visión. Retrieved November 14, 2013, from Consejo Nacional de Áreas Protegidas: http://www.conap.gob.gt/index.php/quienes/vision.html

CONAP, \& FONACON. (2004). Plan Maestro 2005-2010 Parque Nacional Rio Dulce. Guatemala City: CONAP.

CONAP, FUNDAECO, \& TNC. (2006). Plan Maestro de la Reserva de Manantiales Cerro San Gil. Guatemala City: CONAP.

Coronado, E. (2014, January 29). Cuestionan plan para promoción. Retrieved March 2, 2014, from Prensa Libre.com: http://www.prensalibre.com/economia/Cuestionan-planpromocion_0_1075092490.html

Crispín, A. S., Beltrán, G. M., \& Frejomil, E. P. (2012). Estructura territorial del turismo en Guatemala. Investigaciones Geográficas, (78), 104-121.

Croes, R., \& Kubickova, M. (2013). From potential to ability to compete: Towards a performance-based tourism competitiveness index. Journal of Destination Marketing \& Management, 2(3), 146-154. 
de Vries, B. J., \& Petersen, A. C. (2009). Conceptualizing sustainable development: An assessment methodology connecting values, knowledge, worldviews and scenarios. Ecological Economics, 68(4), 1006-1019.

Dearden, P., Bennett, M., \& Johnston, J. (2005). Trends in global protected area governance, 1992-2002. Environmental Management, 36(1), 89-100.

Devillers, R., \& Jeansoulin, R. (2006). Fundamentals of spatial data quality. London, UK: ISTE Ltd.

Di Minin, E., Macmillan, D. C., Goodman, P. S., Escott, B., Slotow, R., \& Moilanen, A. (2013). Conservation businesses and conservation planning in a biological diversity hotspot. Conservation Biology, 27(4), 1-13.

Diamantis, D., \& Ladkin, A. (1999). The links between sustainable tourism and ecotourism: A definitional and operational perspective. The Journal of Tourism Studies, 10(2), 35-46.

Drumm, A. E. (2013). An examination of the roles and responsibilities of the tourism business sector and the opportunity for collaborative destination management in Santa Catalina, Panama. Theses and dissertations: Ryerson University.

Eagles, P. F., McCool, S. F., \& Haynes, C. (2002). Sustainable tourism in protected areas: Guidelines for planning and management. Madrid, Spain: World Tourism Organization.

Eagles, P. F., Romagosa, F., Buteau-Duitschaever, W. C., Havitz, M., Glover, T. D., \& McCutcheon, B. (2013). Good governance in protected areas: an evaluation of stakeholders' perceptions in British Columbia and Ontario Provincial Parks. Journal of Sustainable Tourism, 21(1), 60-79.

European Commission. (2007). Guatemala Country Strategy Paper 2007 - 2013. Retrieved from European Union External Action: http://eeas.europa.eu/guatemala/csp/07_13_en.pdf 
Freytag, A., \& Vietze, C. (2013). Can nature promote development? The role of sustainable tourism for economic growth. Journal of Environmental Economics and Policy, 2(1), 1644.

FUNDAECO. (2011). Shore excursions for cruise travelers. Retrieved October 28, 2013, from The Conservation Coast: http://www.conservationcoast.com/shoreexcursions.htm

Geneletti, D., \& Dawa, D. (2009). Environmental impact assessment of mountain tourism in developing regions: A study in Ladakh, Indian Himalaya. Environmental Impact Assessment Review, 29(4), 229-242.

Gonzalez, M., Gonzalez, X. M., Polome, P., \& Prada, A. (2002). Public management of a popular protected nature area: An application to the Cies Islands. In N. Andrews, F. Convery, S. Flanagan, \& J. Ruddy, Tourism and the environment: Sustainability in tourism development (pp. 143-161). Dublin, Ireland: Dublin Institute of Technology.

Gunn, C. A. (1994). The emergence of effective tourism planning and development. In A. V. Seaton, Tourism: The state of the art (pp. 10-19). Chichester, UK: John Wiley \& Sons. GWP \& INBO. (2009). A handbook for integrated water resources management in basins. Stockholm, Sweden: GWP \& INBO.

Haklay, M. (2010). How good is volunteered geographical information? A comparative study of OpenStreetMap and Ordnance Survey datasets. Environment and Planning B: Planning and Design, 37, 682-703.

Hall, C. M. (2011). Fieldwork in tourism/touring fields: Where does tourism end and fieldwork begin? In C. M. Hall, Fieldwork in tourism: Methods, issues and reflections (pp. 19-34). Oxford, UK: Routledge. 
Hall, C. M., \& Page, S. (2009). Progress in tourism management: from the geography of tourism to geographies of tourism - A review. Tourism Management, 30(1), 3-16.

Harris, R. W. (2009). Tourism in Bario, Sarawak, Malaysia: A case study of pro-poor community-based tourism integrated into community development. Asia Pacific Journal of Tourism Research, 14(2), 125-135.

Harrison, D. (2008). Pro-poor tourism: a critique. Third World Quarterly, 29(5), 851-868.

Hassanali, K. (2013). Towards sustainable tourism: The need to integrate conservation and development using the Buccoo Reef Marine Park, Tobago, West Indies. Natural Resources Forum, 37(2), 90-102.

Hearne, R. R., \& Santos, C. A. (2005). Tourists' and locals' preferences toward ecotourism development in the Maya Biosphere Reserve, Guatemala. Environment, Development and Sustainability, 7(3), 303-318.

Herrera, A. M., \& Dardón, B. (2014, February 6). Competitividad no se perderá. Retrieved February 27, 2014, from Prensa Libre.com: http://www.prensalibre.com/noticias/Competitividad-perdera_0_1079892032.html

Holden, A. (2009). The environment-tourism nexus: Influence of market ethics. Annals of Tourism Research, 36(3), 373-389.

Hopkins, K. W., \& Price, G. G. (2002). Ecotourism's competitive advantage?: Environmental education. In N. Andrews, F. Convery, S. Flanagan, \& J. Ruddy, Tourism and the environment: Sustainability in tourism development (pp. 131-142). Dublin, Ireland: Dublin Institue of Technology. 
INE. (2013). Población en Guatemala (demografia). Retrieved October 10, 2013, from Instituto Nacional de Estadistica: Guatemala C. A. : http://www.ine.gob.gt/np/poblacion/index.htm

INGUAT. (2013). Boletín Anual Estadísticas de Turismo 2012. Guatemala City: Gobierno de Guatemala.

INGUAT. (n.d.). Misión y visió. Retrieved September 16, 2013, from Instituto Guatemalteco de Turismo - Gobierno de Guatemala: http://www.inguat.gob.gt/mision-vision.html

Ixcot Yon, L. C. (2005). Plan de monitoreo para el Biotopo Chocón-Machacas con identificación de al menos dos indicadores biológicos a investigar. Guatemala: CECON.

Joerger, A., DeGloria, S. D., \& Noden, M. A. (1999). Applying Geographic Information Systems: Siting of coastal hotels in Costa Rica. Cornell Hotel and Restaurant Administration Quarterly, 40(4), 48-59.

Kekeotripz. (n.d.). Izabal Hotels. Retrieved August 28, 2013, from Kekeotripz: http://kekeotripz.com/ubication/izabal/?post_type=hotels

Kitamura, K., \& Clapp, R. A. (2013). Common property protected areas: Community control in forest conservation. Land Use Policy, 34, 204-212.

Lélé, S. M. (1991). Sustainable development: A critical review. World Development, 19(6), 607621.

Lew, A. A. (2011). Defining and redefining conceptual frameworks for social science field research. In C. M. Hall, Fieldwork in tourism: Methods, issues and reflections (pp. 1934). Oxford, UK: Routledge.

Lyon, S. (2013). Coffee tourism and community development in Guatemala. Human Organization, 72(3), 188-198. 
MacKay, K. J., \& Campbell, J. M. (2004). A mixed-method approach for measuring environmental impacts in nature-based tourism and outdoor recreation settings. Tourism Analysis, 9(3), 141-152.

MacKay, K. J., \& Campbell, J. M. (2012). Innovative community tourism in Uganda: International tourists, national networks, and local livelihoods. Téoros, Special Issue: Innovations in Sustainable Tourism, 59-64.

Maxwell, K. (2012). Tourism, environment, and development on the Inca Trail. Hispanic American Historical Review, 92(1), 143-171.

McGehee, N. G., Boleya, B. B., Hallob, J. C., McGee, J. A., Norman, W., Oh, C.-O., et al. (2013). Doing sustainability: an application of an inter-disciplinary and mixed-method approach to a regional sustainable tourism project. Journal of Sustainable Tourism, 21(3), $355-375$.

Medina, C. E., Gomez-Enri, J., Alonso, J. J., \& Villares, P. (2008). Water level fluctuations derived from ENVISAT Radar Altimeter (RA-2) and in-situ measurements in a subtropical waterbody: Lake Izabal (Guatemala). Remote Sensing of Environment, 112(9), 3604-3617.

Merriam, S. B. (2002). Assessing and evaluating qualitative research. In S. B. Merriam, Qualitative research in practice: Examples for discussion and analysis (pp. 18-36). San Francisco, CA: Jossey-Bass.

Moran-Cahusac, C. (2009). Ecotourism in Podocarpus National Park. Journal of Sustainable Forestry, 28, 777-798.

Moreno, J., \& Littrell, M. A. (2001). Negotiating tradition: Tourism retailers in Guatemala. Annals of Tourism Research, 28(3), 658-685. 
Mozmuder, P., Berrens, R. P., \& Bohara, A. K. (2006). Is there an environmental Kuznets curve for the risk of biodiversity loss? The Journal of Developing Areas, 39(2), 175-190.

Muñoz, G. (2013, July 3). Turismo crece $6.3 \%$ entre enero y mayo de 2013. Retrieved July 5, 2013, from Siglo21.com.gt: http://www.s21.com.gt/node/306597

Nahuelhual, L., Carmona, A., Lozada, P., Jaramillo, A., \& Aguayo, M. (2013). Mapping recreation and ecotourism as a cultural ecosystem service: An application at the local level in Southern Chile. Applied Geography, 40, 71-82.

NREL. (2011). Guatemala geospatial data. Guatemala. Retrieved from: http://en.openei.org/datasets/node/665

Okazaki, E. (2008). A community-based tourism model: Its conception and use. Journal of Sustainable Tourism, 16(5), 511-529.

Ólafsdóttir, R., \& Runnström, M. C. (2009). A GIS approach to evaluating ecological sensitivity for tourism development in fragile environments. A case study from SE Iceland. Scandinavian Journal of Hospitality and Tourism, 9(1), 22-38.

Patton, M. Q. (2002). Qualitative reseach and evaluation methods. Thousand Oaks, CA: Sage Publications, Inc.

Pérez, A. (2009, January 1). Inguat cobrará US\$10 a pasajeros de cruceros a partir del 15 de enero. Retrieved February 7, 2014, from El Periódico: http://www.elperiodico.com.gt/es/20090101/pais/84916/

Perlack, R. D., Ensminger, J. T., \& Martinez, R. (2001). Guatemala strives for environmental and economic sustainability in the Rio Dulce region. Natural Resources Forum, 25(3), 235-244. 
Peters, M., \& Weiermair, K. (2002). Development of sustainable tourism: The role of small- and medium-sized enterprises. In N. Andrews, F. Convery, S. Flanagan, \& J. Ruddy, Tourism and the environment: Sustainability in tourism development (pp. 2-9). Dublin, Ireland: Dublin Institute of Technology.

Quental, N., Lourenço, J. M., \& da Silva, F. N. (2011). Sustainable development policy: Goals, targets and political cycles. Sustainable Development, 19(1), 15-29.

Reinius, S. W. (2011). Researching tourists in the outdoors: Challenges and experiences from protected areas in Sweden. In C. M. Hall, Fieldwork in tourism: Methods, issues and reflections (pp. 232-239). Oxford, UK: Routledge.

Reynisdottir, M., Song, H., \& Agrusa, J. (2008). Willingness to pay entrance fees to natural attractions: An Icelandic case study. Tourism Management, 29(6), 1076-1083.

Rinner, C., \& Düren, M. (2011). Design with nature 2.0 - A geodata infrastructure approach to map overlay. In A. Schwering, E. Pebeszma, \& K. Behncke, Geoinformatik 2011 Geochange (pp. 21-28). Heidelberg, Germany: ifgiPrints.

Roth, R. E. (2009). A qualitative approach to understanding the role of geographic information uncertainty during decision making. Cartography and Geographic Information Science, 36(4), 315-330.

Salazar, N. B. (2012). Community-based cultural tourism: issues, threats and opportunities. Journal of Sustainable Tourism, 20(1), 9-22.

SEGEPLAN. (2011). Plan de Desarollo Departamental. Guatemala City: Secretaría de Planificación y Programación de la Presidencia. 
SIGAP. (2013). Route of the Green Caribbean . Retrieved May 29, 2013, from Journey Through the Protected Areas of Guatemala: http://www.turismo-sigap.com/en/route-of-the-greencaribbean

Smith, B. G., \& Ley, D. (2009). Sustainable tourism and clean water project for two Guatemalan communities: A case study. Desalination, 248, 225-232.

Sneddon, C., Howarth, R. B., \& Norgaard, R. B. (2006). Sustainable development in a postBrundtland world. Ecological Economics, 57(2), 253-268.

Stake, R. E. (1978). The case study method in social inquiry. Educational Researcher, 7(2), 5-8.

Steinberg, M. K., \& Taylor, M. J. (2003). Public memory and political power in Guatemala's postconflict landscape. Geographical Review, 93(4), 449-468.

Streeter, S. M. (1999). The failure of 'liberal developmentalism': The United States's antiCommunist showcase in Guatemala, 1954-1960. The International History Review, 21(2), 386-413.

Sundberg, J. (1998). NGO landscapes in the Maya Biosphere Reserve, Guatemala. The Geographical Review, 88(3), 388-412.

Tanguay, G. A., Rajaonson, J., \& Therrien, M.-C. (2013). Sustainable tourism indicators: selection criteria for policy implementation and scientific recognition. Journal of Sustainable Tourism, 21(6), 862-879.

Timur, S., \& Getz, D. (2009). Sustainable tourism development: how do destination stakeholders perceive sustainable urban tourism? Sustainable Development, 17(4), 220-232.

Torres-Delgado, A., \& Palomeque, F. L. (2012). The growth and spread of the concept of sustainable tourism: The contribution of institutional initiatives to tourism policy. Tourism Management Perspectives, 4, 1-10. 
Tremblay, P., Pearson, D., \& Gorman, J. (2008). Destination planning and the sustainability of wildlife tourism resources: Ongoing challenges for knowledge integration. Tourism and Hospitality Planning \& Development, 5(3), 257-276.

UNEP-WCMC. (2013). Statistical Annex: Millennium Development Goals, Targets and Indicators, 2013. New York, NY: United Nations (UN).

Valladares, D. (2012, December 17). Deforestation wreaks havoc in Guatemala's Caribbean region. Retrieved October 7, 2013, from Inter Press Service News Agency: http://www.ipsnews.net/2012/12/deforestation-wreaks-havoc-in-guatemalas-caribbeanregion/

Vellas, F. (2002). Evaluation of tourism projects with indicators of sustainable development. In N. Andrews, F. Convery, S. Flanagan, \& J. Ruddy, Tourism and the environment: Sustainability in tourism development (pp. 58-71). Dublin, Ireland: Dublin Institute of Technology.

Vuohelainen, A. J., Coad, L., Marthews, T. R., Malhi, Y., \& Killeen, T. J. (2012). The effectiveness of contrasting protected areas in preventing deforestation in Madre de Dios, Peru. Environmental Management, 50(4), 645-663.

Wallace, T., \& Diamente, D. N. (2005). Keeping the people in the parks: A case study from Guatemala. NAPA Bulletin, 23(1), 191-218.

WCED. (1987). Our Common Future. Oxford, UK: Oxford University Press.

Wilson, T. D., \& Ypeij, A. (2012). Tourism, gender, and ethnicity. Latin American Perspectives, $39(6), 5-16$.

WTO \& UNEP. (2008). Climate change and tourism: Responding to global challenges. Madrid, Spain: WTO \& UNEP. 
WTO. (2004). Indicators of sustainable development for tourism destinations: A guidebook. Madrid, Spain: UNWTO.

WTO. (2013). Tourism in the Americas - 2013 Edition. Madrid, Spain: UNWTO.

Yáñez-Arancibia, A., Zárate Lomelí, D., Gómez Cruz, M., Godínez Orantes, R., \& Santiago

Fandiño, V. (1999). The ecosystem framework for planning and management the Atlantic coast of Guatemala. Ocean \& Coastal Management, 42, 283-317. 